
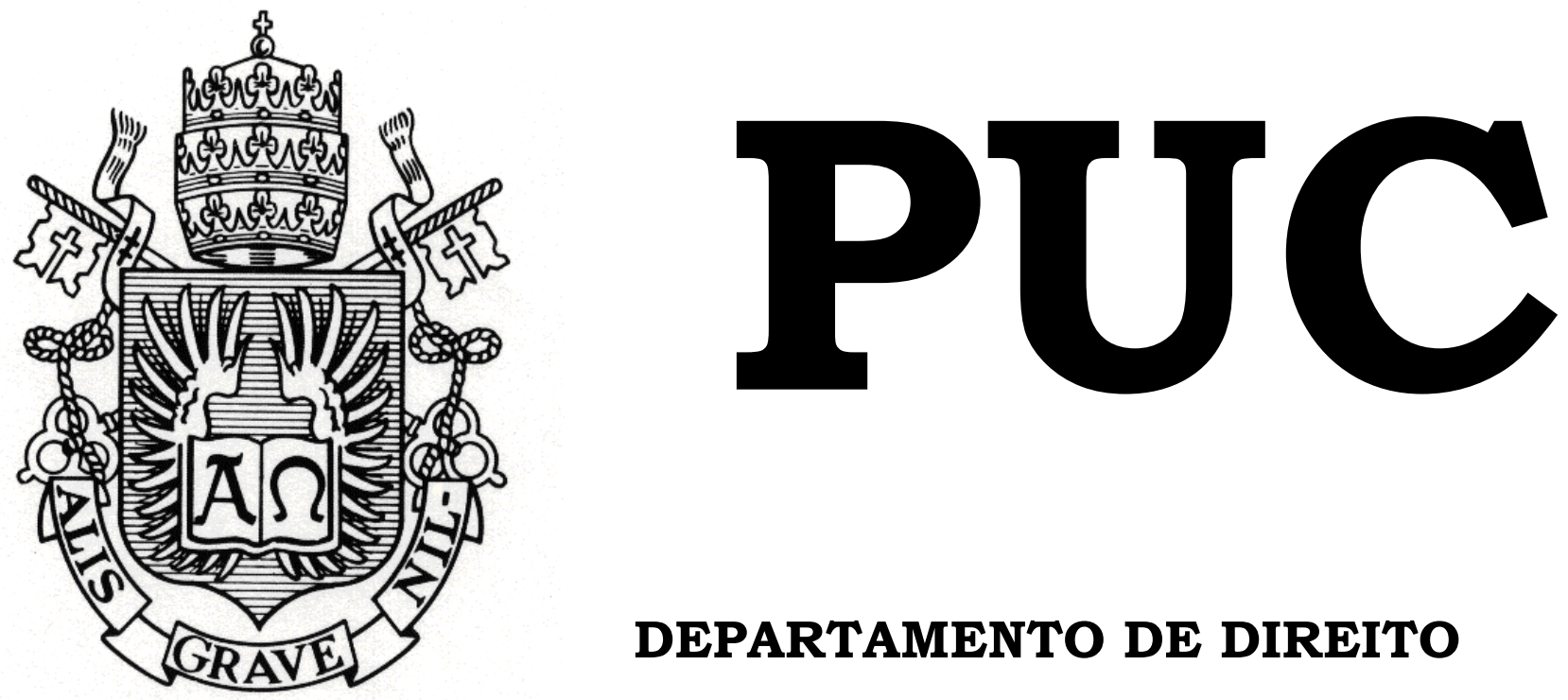

DEPARTAMENTO DE DIREITO

\title{
A POSSIBILIDADE DE ENRIQUECIMENTO PATRIMONIAL DO CÔNJUGE E DO COMPANHEIRO NA PERSPECTIVA DO CÓDIGO CIVIL DE 2002
}

por

ANA CAROLINA VELMOVITSKY

Orientador: LUCIANO VIANNA ARAÚJO

2015.2

PONTIFÍCIA UNIVERSIDADE CATÓLICA DO RIO DE JANEIRO

RUA MARQUÊS DE SÃO VICENTE, 225 - CEP 22453-900

RIO DE JANEIRO - BRASIL 


\section{A POSSIBILIDADE DE ENRIQUECIMENTO PATRIMONIAL DO CÔNJUGE E DO COMPANHEIRO NA PERSPECTIVA DO CÓDIGO CIVIL DE 2002}

por

ANA CAROLINA VELMOVITSKY

Monografia apresentada ao Departamento de Direito da Pontificia Universidade Católica do Rio de Janeiro (PUC-Rio) como requisito para a obtenção do Título de Bacharel em Direito.

Orientador: Luciano Vianna Araújo 
Dedico esse trabalho acadêmico à minha família, com destaque para meu pai Arnon, minha mãe Lenise, e meus irmãos Alex e Rachel pelo apoio e carinho em todas as etapas da minha vida.

Agradeço, também, ao meu namorado, Patrick, por toda compreensão e carinho.

Não poderia deixar de manifestar minha gratidão aos meus avós, Paulo, Salomão e Lea.

Esse trabalho é especialmente dedicado a minha avó Etília, por todo o amor que me foi dedicado e por ser um grande exemplo pra $\operatorname{mim}$.

Agradeço também ao Professor Luciano Vianna Araújo, por quem nutro grande admiração, por ter me orientado no curso deste trabalho, com tanta dedicação e paciência. 
VELMOVITSKY, Ana Carolina. A POSSIBILIDADE DE ENRIQUECIMENTO PATRIMONIAL DO CÔNJUGE E DO COMPANHEIRO NA PERSPECTIVA DO CÓDIGO CIVIL DE 2002. Rio de Janeiro, 2015. 112 p. Monografia de final de curso - Departamento de Direito, Pontifícia Universidade Católica do Rio de Janeiro.

O presente trabalho tem por objetivo verificar qual é o regime de bens que gera maior enriquecimento patrimonial para o cônjuge e/ou companheiro na perspectiva do Código Civil de 2002.

Para tanto, analisar-se-á as peculiaridades dos regimes de bens previstos no Código Civil de 2002, os efeitos patrimoniais da união estável, bem como suas repercussões na sucessão legítima do cônjuge e/ou do companheiro sobrevivente.

Nesse sentido, examinar-se-ão quais os benefícios e malefícios de cada regime de bens para o patrimônio do cônjuge ou companheiro, as discussões doutrinárias e jurisprudências referentes à concorrência do cônjuge e do companheiro com os descendentes, ascendentes e outros parentes sucessíveis, bem como os institutos do Direito das Sucessões que os beneficiam.

Palavras chave: Direito de família. Regime de bens. Enriquecimento patrimonial. Direito das sucessões. Direito de concorrência. Direito à meação. Partilha de bens. Direito real de habitação. Cônjuge. Companheiro. 


\section{SUMÁRIO}

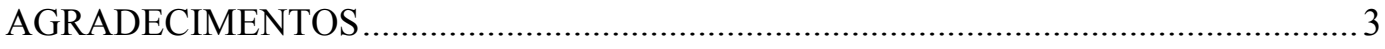

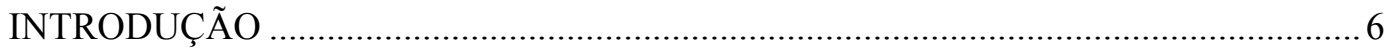

Capítulo I - EFEITOS PATRIMONIAIS DO CASAMENTO E DA UNIÃO ESTÁVEL 8

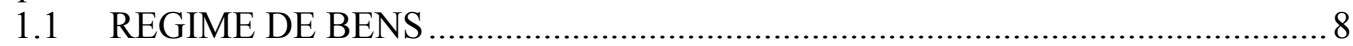

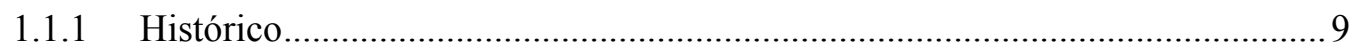

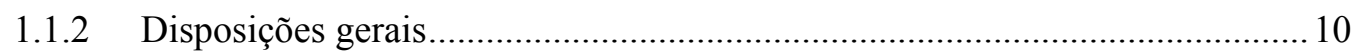

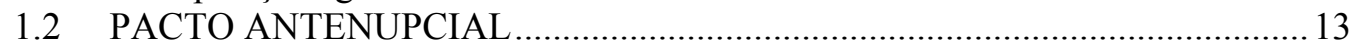

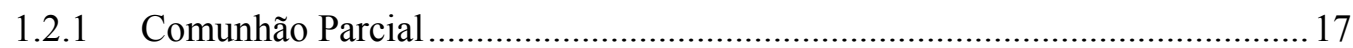

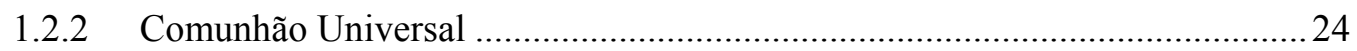

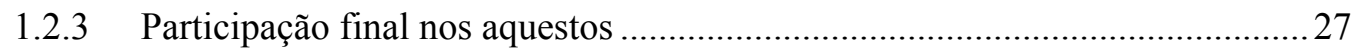

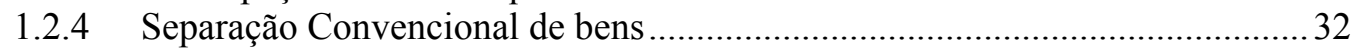

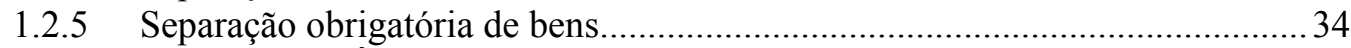

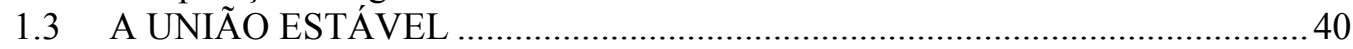

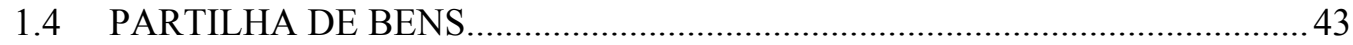

1.5 CASAR OU NÃO CASAR? E SOB QUAL REGIME? .................................... 45

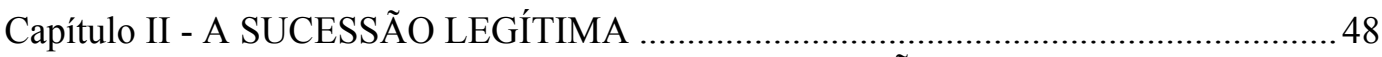

2.1 LINHAS GERAIS DO DIREITO DAS SUCESSÕES E A RESERVA

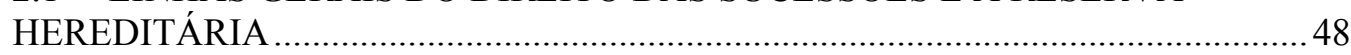

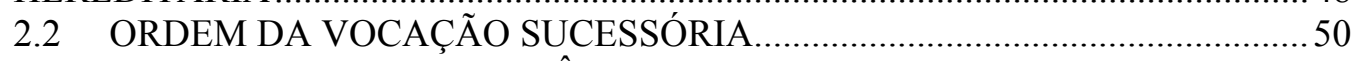

2.3 O DIREITO DE CONCORRÊNCIA ……......................................................... 52

2.4 A EVOLUÇÃO HISTÓRICA DO DIREITO SUCESSÓRIO DO CÔNJUGE E

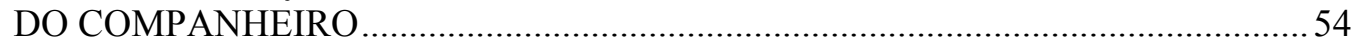

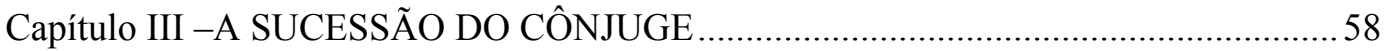

3.1 REQUISITOS DE LEGITIMIDADE PARA SUCEDER ................................58

3.2 O CÔNJUGE EM CONCORRÊNCIA COM OS DESCENDENTES ................62

3.2.1 Controvérsias sobre o direito à concorrência ...................................................63

3.2.2 Quinhão mínimo do cônjuge em concorrência com descendentes ...................73

3.3 O CÔNJUGE EM CONCORRÊNCIA COM OS ASCENDENTES ...................74

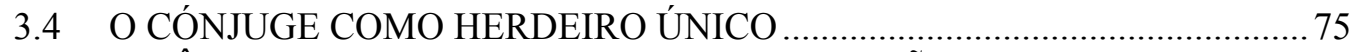

3.5 O CÔNJUGE E O DIREITO REAL DE HABITAÇÃO …................................76

3.6 QUAL REGIME DE BENS GARANTE O MAIOR ACERVO PATRIMONIAL

PARA O CÔNJUGE SOBEVIVENTE? .................................................................... 78

Capítulo IV - A SUCESSÃO DO COMPANHEIRO ....................................................... 82

4.1 CRÍTICAS AO ARTIGO 1.790, DO CÓDIGO CIVIL: O COMPANHEIRO É

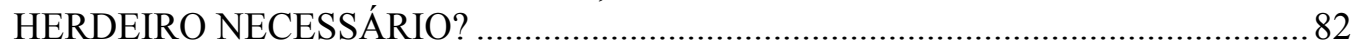

4.2 MASSA DE BENS SOBRE A QUAL INCIDEM OS DIREITOS

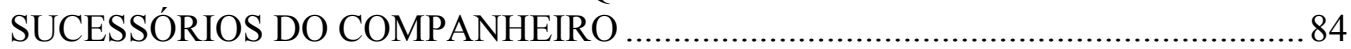

4.2 O COMPANHEIRO EM CONCORRÊNCIA COM OS DESCENDENTES ....89

4.3 O COMPANHEIRO EM CONCORRÊNCIA COM OUTROS PARENTES ....99

4.4 O COMPANHEITO COMO HERDEIRO ÚNICO .........................................95

4.5 O COMPANHEIRO E O DIREITO REAL DE HABITAÇÃO ..........................95

4.6 AFINAL, O REGIME SUCESSÓRIO DO COMPANHEIRO É BEM

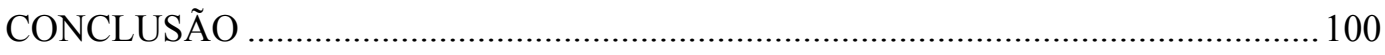

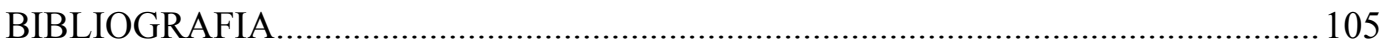

ANEXOS 


\section{LISTA DE ABREVIAÇÕES}

AG - $\quad$ Agravo de Instrumento

AgRg - Agravo regimental

CC - Código Civil de 2002

Des. - Desembargador

DJU - Diário de Justiça da União

Emb. - Embargos de declaração

j. - Julgado

Min. - Ministro

p. - página

Rel. - Relator

REsp - Recurso Especial

RE - Recurso Extraordinário

STJ - $\quad$ Superior Tribunal de Justiça

STF - $\quad$ Supremo Tribunal Federal

TJRJ - Tribunal de Justiça do Estado do Rio de Janeiro

CF - Constituição Federal de 2002 
Essa monografia tem como objetivo analisar os efeitos patrimoniais da união estável e dos regimes de bens do casamento, a fim de verificar, no âmbito do direito de família e do direito das sucessões, qual regime permite maior aquisição patrimonial para o cônjuge ou para o companheiro, na perspectiva do Código Civil.

Para tanto, em um primeiro momento, o estudo será pautado na análise dos regimes de bens previstos pelo Código Civil de 2002, os efeitos patrimoniais da união estável, bem como a forma de divisão de bens, nas duas entidades familiares, durante a sua vigência e após a sua dissolução.

Posteriormente, serão analisadas algumas regras gerais do direito das sucessões, com o intuito de restringir o objeto de estudo desse trabalho.

Por fim, analisar-se-á as sucessões legítimas do cônjuge e do companheiro, segundo as regras previstas pelo Código Civil de 2002. Nessa oportunidade, serão analisados não apenas o histórico da evolução dos direitos sucessórios do cônjuge e do companheiro, mas também as hipóteses de concorrência entre o cônjuge e o companheiro com os descendentes, ascendentes e outros parentes sucessíveis.

Serão estudadas, ainda, as hipóteses em que o cônjuge e o companheiro são herdeiros únicos e em que fazem jus ao direito real de habitação.

Como se verá, a discussão sobre os direitos sucessórios do cônjuge e do companheiro é bastante polêmica, não apenas pelo Código Civil ter condicionado o direito de concorrência do cônjuge, com descendentes, ao regime de bens escolhido no pacto antenupcial, mas também pela diferença de tratamento que a lei destina ao cônjuge e ao companheiro sobrevivente.

Serão apontadas, também, as críticas feitas às redações de vários dispositivos, em especial, a do artigo 1.790, do Código Civil, que regula a 
sucessão do companheiro, e os projetos de lei apresentados com o intuito de solucionar algumas controvérsias.

Assim, a fim de obter uma visão mais ampla sobre o tema, serão expostas as principais correntes doutrinárias e jurisprudenciais para que, com base nelas, sejam verificadas quais situações são mais vantajosas economicamente para o cônjuge e para o companheiro. Vale lembrar, neste ponto, que, diante das peculiaridades previstas em lei, para obter uma resposta mais profunda, é importante fazer uma análise de cada caso concreto. 


\section{Capítulo I - EFEITOS PATRIMONIAIS DO CASAMENTO E DA UNIÃO ESTÁVEL}

\subsection{REGIME DE BENS}

A Constituição Federal, em seu artigo 226, estabelece que a família é a base da sociedade e, por isso, possui proteção especial do Estado. Historicamente, a família nasce com a celebração do casamento civil (artigo $226, \S \S 1^{\circ}$ e $2^{\circ}$ da Constituição Federal), por meio do qual os nubentes, por vontade própria e com a chancela do Estado, estabelecem uma comunhão plena de vidas, com base na igualdade de direitos e deveres recíprocos entre eles (artigos 1.511 e 1.565 do Código Civil).

Entre os deveres assumidos pelos nubentes estão os da solidariedade e os da mútua assistência (artigo 1.566, III, do Código Civil), o que implica no compromisso de cada cônjuge contribuir com os custos e gastos dentro de sua disponibilidade, de modo que ambos são responsáveis pelos encargos e pela subsistência da família (artigo 1.565 do Código Civil).

Nessa perspectiva, a comunhão plena de vidas gera, entre os nubentes, não apenas efeitos sociais e pessoais, mas também um entrelaçamento de bens, rendas, responsabilidades e outros efeitos patrimoniais, criando o que já foi designado de "patrimônio familial"1.

Para evitar conflitos, a lei prevê que as questões econômicas devem ser discutidas antes mesmo do casamento, com a celebração do pacto antenupcial, cujo objetivo é a eleição de um regime de bens que vai regular o patrimônio da família. Contudo, o regime patrimonial escolhido só começa a vigorar a partir da celebração do casamento.

Nas palavras de Gustavo Tepedino, Heloisa Barboza e Maria Celina Bodin de Moraes, o regime de bens é um "estatuto patrimonial do casamento que, segundo o art. 1.639, caput, é informado pela mais ampla

\footnotetext{
${ }^{1}$ PEREIRA, Caio Mário da Silva. Instituições de Direito Civil: Direito de Família, vol. V. $23^{\mathrm{a}}$ ed.
} atualizado por Tânia da Silva Pereira. Rio de Janeiro: Forense, 2015. 192 p. 
liberdade de escolha dos cônjuges."”. No mesmo sentido, Caio Mario da Silva Pereira conceitua o regime de bens como "os princípios jurídicos que disciplinam as relações econômicas entre os cônjuges, na constância do matrimônio". 3

Esclareça-se, ainda, que a todos os regimes de bens são aplicadas as regras do regime matrimonial primário (artigos 1.639 a 1.652), normas de ordem pública que buscam regular questões como a administração dos bens, atos de disposição e dívidas do casal.

O Código Civil de 2002 inovou ao permitir que ambos os cônjuges pleiteiem a alteração do regime de bens, desde que o pedido seja motivado. Analisada a procedência das razões invocadas, o juiz autoriza a alteração, ressalvado os direitos de terceiros.

Dessa forma, o regime de bens estabelece as regras que deverão ser aplicadas ao patrimônio do casal durante a constância do casamento e, principalmente, quando de sua dissolução pelo divórcio ou morte de um dos consortes.

\subsubsection{Histórico}

Na vigência do Código Civil de 1916, a única entidade familiar reconhecida pelo legislador era a que nascia com o casamento. Dentro dessa lógica, o casamento era indissolúvel e, por constituir comunhão plena de vidas e de patrimônio, o regime legal era o da comunhão universal de bens. Ou seja, todo o patrimônio do casal era amealhado, independentemente de sua origem ou momento de aquisição.

Em 1962 foi editado o Estatuto da Mulher casada (Lei $n^{\circ}$ 4.121/62), cujo objetivo era proteger a esposa. Segundo este estatuto, os chamados bens reservados, aqueles que eram adquiridos pela mulher com o fruto de

\footnotetext{
${ }^{2}$ TEPEDINO, Gustavo et al.. Código Civil Interpretado: Conforme a Constituição da República, vol. IV. $1^{a}$ ed. Rio de Janeiro: Renovar, 2014. 257 p.

${ }^{3}$ PEREIRA, Caio Mário da Silva. Op. Cit.,. 217 p.
} 
seu trabalho, eram incomunicáveis. Porém, com a Constituição Federal de 1988, que consagrou o princípio da igualdade entre homem e mulher, este instituto foi extinto.

Em 1977, com a Lei do Divórcio (Lei no 6.515/77), a fim de atender a nova realidade da mulher que "deixa de ser mera colaboradora com a administração do marido, para ser cogestora da sociedade conjugal"4, o regime legal deixou de ser o da comunhão total e passou a ser o da comunhão parcial. O novo regime supletivo, salvo algumas exceções previstas em lei ou em pacto antenupcial, se caracteriza pela comunicação dos bens adquiridos onerosamente durante o período da vida em comum.

Em um momento posterior, com a promulgação do Código Civil de 2002, apesar da comunhão parcial ser mantida como regime supletivo, foi excluído, por desuso, o regime dotal e incluído em seu lugar de participação final nos aquestos.

\subsubsection{Disposições gerais}

O regime matrimonial primário está disposto nos artigos 1.639 a 1.653 do Código Civil. Por serem aplicadas a todos os regimes de bens, nos comentários a cada um desses regimes muitas das regras de disposições gerais serão novamente comentadas, porém de forma mais minuciosa.

Grande parte dos artigos que tratam sobre as disposições gerais dos regimes abordam questões ligadas à administração e à disposição dos bens. Para tanto, o Código faz uma distinção entre atos que o cônjuge pode praticar sozinho e atos em que é necessária a autorização do outro cônjuge durante o casamento.

Ao cônjuge é permitido, sem a outorga do outro cônjuge:

\footnotetext{
${ }^{4}$ TUCCI, Cibele Pinheiro Marcal. Aspectos Patrimoniais do Direito de Família no Brasil. In: AZEVEDO, Álvaro Vilaça (Org.) Revista Nacional de Família e Sucessões. Porto Alegre: Magister, 2014. p.44.
} 
(i) praticar todos os atos de disposição e de administração necessários ao desempenho de sua profissão - contudo, para alienar ou gravar de ônus real bens imóveis é necessária a autorização do cônjuge, salvo quando for regime de separação de bens;

(ii) administrar os bens próprios;

(iii) desobrigar ou reivindicar os imóveis que tenham sido gravados ou alienados sem o seu consentimento ou sem suprimento judicial;

(iv) demandar a rescisão dos contratos de fiança e doação, não remuneratória, de bens comuns ou que possam integrar futura meação, ou a invalidação do aval, realizados pelo outro cônjuge sem sua autorização, desde que não seja regime de separação de bens;

(v) reivindicar os bens comuns, móveis ou imóveis, doados ou transferidos pelo outro cônjuge ao concubino, desde que provado que os bens não foram adquiridos pelo esforço comum destes, se o casal estiver separado de fato por mais de cinco anos; e

(vi) praticar todos os atos que não lhes forem vedados expressamente.

Nas hipóteses (iii), (iv) e (v), são partes legítimas para ajuizar a ação cabível o cônjuge prejudicado ou seus herdeiros.

$\mathrm{O}$ artigo 1.643 também permite que o cônjuge compre, ainda que a crédito, bens necessários à economia doméstica cotidiana, bem como obtenha empréstimos para adquirir tais bens. Uma vez contraídas dívidas com este fim, elas obrigam solidariamente ambos os cônjuges. Sobre esse ponto, a doutrina entende estarem excluídos desse rol bens de natureza supérflua ou de luxo.

Conforme observado acima, exceto nos casos em que vigore o regime da separação absoluta, o cônjuge deve pedir autorização ao outro para (i) alienar ou gravar de ônus real os bens imóveis; (ii) pleitear, como autor ou réu, acerca desses bens ou direitos; (iii) prestar fiança ou aval; e (iv) fazer doação, não sendo remuneratória, de bens comuns, ou dos que possam 
integrar futura meação. Cabe, aqui, a ressalva de que são válidas, ainda que feita por apenas um dos cônjuges, sem autorização do outro, as doações feita aos filhos quando casarem ou estabelecerem economia separada.

Segundo o artigo 73 do Código de Processo Civil de 2015, quando o regime de bens não for o da separação absoluta, um cônjuge necessitará do consentimento do outro para propor ação que verse sobre direito real imobiliário. Seguindo a mesma lógica, o $\S 1^{\circ}$ do dispositivo determina que, salvo quando o regime for de separação absoluta, ambos os cônjuges devem ser citados para ação: (i) que verse sobre direito real imobiliário; (ii) resultante de fato que diga respeito a ambos os cônjuges ou de ato praticado por eles; (iii) fundada em dívida contraída por um deles a bem da família; ou (iv) que tenha por objeto o reconhecimento, a constituição ou extinção de ônus sobre imóvel de um ou ambos os cônjuges. No que tange às ações possessórias, o $\S 4^{\circ}$ do artigo 73 do Código de Processo Civil diz que o cônjuge do autor ou do réu só participará se houver composse ou se o ato tiver sido praticado por ambos.

Se o outro cônjuge não autorizar a prática dos atos listados acima sem motivo justo, ou não for possível obter a autorização do outro consorte, o juiz poderá suprimir a outorga uxória ou marital. Não obtendo a autorização do outro cônjuge ou o suprimento judicial, se o ato for praticado, este será anulável. Para isso, o outro cônjuge, ou seus herdeiros, deve ajuizar ação anulatória dentro do prazo de dois anos, após a dissolução da sociedade conjugal.

No entanto, se o outro cônjuge aprovar o ato realizado sem sua autorização por meio de instrumento público ou particular autenticado, o ato é convalidado, não sendo possível sua posterior anulação.

Importante atentar para a diferença entre a alienação de bem comum e bem próprio:

"Haverá enorme diferença, quer se trate de bem comum ou de bem particular pertencente a outro. Se o bem for comum, nenhum dos cônjuges detêm legitimação para alienar ou gravar a sua totalidade, sem a participação do condômino, seu consorte. Não se trata de mero 
consenso, mas de falta de titularidade para dispor de mais do que cotaparte ideal. Já se o bem for particular, aquele que detiver a titularidade integral sobre ele ostenta, por certo, de legitimação para aliená-lo ou onerá-lo, mas dependerá da anuência do outro, sempre que a lei exigir."

No que concerne à administração, a cada cônjuge cabe a gestão de seus bens particulares e a ambos a administração dos bens comuns. Quando, porém, um cônjuge não puder exercer a gestão dos bens que lhe incumbe,

caberá ao outro gerir os bens comuns e os bens próprios do outro consorte. Durante sua gestão, o cônjuge poderá alienar livremente os bens móveis comuns, no entanto, para alienar os bens imóveis comuns ou os bens de qualquer natureza do outros cônjuge é necessária autorização judicial.

Estando na posse dos bens particulares do outro consorte, o cônjuge será responsável pelos atos por ele praticados. Sua responsabilidade varia de acordo com a posse, ou seja, se os bens forem utilizados para as despesas da família, o cônjuge gestor será considerado usufrutuário, aplicando-lhe as regras do usufruto. Se, porém, houver mandado expresso ou tácito delegando-lhe a gestão dos bens, será considerado procurador. Por fim, não sendo o caso de uma das hipóteses anteriores, o cônjuge será considerado depositário, devendo cumprir com os deveres atribuídos a este cargo, principalmente o de restituir todos os bens e seus frutos.

Essas são algumas das regras básicas e imperativas que devem ser respeitadas. Diante da sua importância e de seu caráter geral, elas serão novamente comentadas quando aplicáveis especificamente em cada um dos regimes de bens.

\subsection{PACTO ANTENUPCIAL}

O pacto antenupcial é o instrumento por meio do qual os nubentes elegem o regime de bens que vigorará durante o casamento. À exceção do 
regime de comunhão parcial que pode ser escolhido por simples termo por ser o regime supletivo, para que vigore qualquer outro regime durante o casamento é imprescindível a celebração de um pacto.

Por ser um ato solene, o pacto deve observar a forma de escritura pública exigida por lei, sob pena de ser considerado nulo. $\mathrm{O}$ instrumento é firmando durante o processo de habilitação do casamento, porém só produzirá seus efeitos após a celebração válida do enlace matrimonial. Assim, mesmo que existente e válido, os efeitos ficam suspensos até que se implemente a condição prevista por lei.

Apesar de ser um ato público, para que produza efeitos perante terceiros, o pacto antenupcial deve ser transcrito em livro especial pelo oficial do Registro de Imóveis do domicílio dos cônjuges.

A lei prevê, ainda, que o pacto antenupcial celebrado por menor só terá validade se houver autorização expressa do representante legal no próprio instrumento, que deverá ser subscrito pelos nubentes e pelo representante legal.

A doutrina não alcançou uma posição unânime quanto à natureza jurídica do pacto antenupcial. Alguns autores, como Caio Mario da Silva Pereira, o consideram um contrato; outros, tais como Paulo Lôbo, entendem ser um negócio jurídico.

Independentemente da posição doutrinária a que se filiem, todos os autores concordam que, por ser uma consequência jurídica do casamento, não se pode conceber uma união matrimonial sem que fique estabelecido um regime de bens. Por isso, quando não ocorrer uma das hipóteses de imposição legal do regime de separação obrigatória, previstas no artigo 1.641 do Código Civil, os nubentes devem escolher um regime para regular os bens da família, sob pena de vigorar o regime supletivo.

Para facilitar a escolha do pacto nupcial, o Código Civil proporciona alguns modelos de regime de bens pré-fabricados que podem ser integralmente utilizados pelas partes (tipos primários), ou que podem servir 
como parâmetro para que as partes criem seu próprio pacto antenupcial (secundário), desde que respeitados os limites da lei:

\begin{abstract}
"Como a família se torna titular do domínio e da posse do acervo patrimonial que a compõe, são previstos regimes de bens: modelos préfabricados criados pelo legislador e disponibilizados aos nubentes. A inclusão e a exclusão de bens, anteriores ou posteriores ao casamento, ditam as diretrizes dos diversos regimes e servem para definir a origem, a titularidade e o destino do patrimônio conjugal. A separação ou a comunhão dos bens individuais, a comunicabilidade ou não do acervo amealhado depois da união é que permite diferenciar os diversos regimes existentes, mesclá-los, ou, ainda, criar um modelo exclusivo da forma que melhor lhes aprouver. Os companheiros podem fazer isto antes de darem início a união estável e durante a sua vigência, de forma livre, sem a necessidade do amém judicial.

A doutrina traz uma classificação. São chamados tipos primários os quatro regimes previstos na lei. $\mathrm{E}$ de regime de bens secundário a possibilidade de noivos e conviventes, mediante pacto antenupcial ou contrato de convivência, fazerem outras avenças."
\end{abstract}

$\mathrm{Na}$ escolha do regime de bens, prepondera o princípio da autonomia privada: aos cônjuges, é conferida a mais ampla liberdade para estipularem sobre seu estatuto econômico familiar. Podem, portanto, escolher um dos quatro regimes legais (legal); criar, por intermédio de pacto antenupcial, o regime que melhor lhes aprouver (convencional); ou, no silêncio das partes, sujeitar-se ao regime supletivo.

No entanto, esta autonomia encontra limites nos princípios de ordem pública. Os nubentes não poderão eleger regime de bens que afronte a lei, conforme previsto no artigo 1.655 do Código Civil, ou que viole o mínimo ético, como estipulações que contrariem a natureza e os fins do casamento.

Entre os limites à liberdade de estipular as regras do patrimônio matrimonial, Maria Berenice Dias lista as seguintes vedações: " $a$ autonomia da vontade é relativa, pois é proibido: afrontar disposições absoluta de lei (CC1.655); dispor sobre direito sucessório (CC 426); e sobre alimentos (CC 1.707)."7

\footnotetext{
${ }^{6}$ DIAS, Maria Berenice. Manual de Direito das Famílias. $10^{\mathrm{a} e d . ~ S a ̃ o ~ P a u l o: ~ E d i t o r a ~ R e v i s t a ~ d o s ~}$ Tribunais, 2015. p.298.

${ }^{7}$ Ibid, p. $297-298$.
} 
No mesmo sentido, Gustavo Tepedino, Heloisa Barboza e Maria Celina Bodin de Moraes ensinam:

"A liberdade de criação do estatuto do casamento, todavia, não é ilimitada. $\mathrm{O}$ art. 1655, que deve ser lido em conjunto com o caput do art. 1.639, afirma ser nula a convenção ou cláusula que violar disposição absoluta de lei, a exemplo dos impedimentos previstos no art. 1.641, inafastáveis pela vontade das partes, por se tratar de matéria de ordem pública."

Além disso, ocorrendo uma das hipóteses previstas no artigo 1.641 do Código Civil - quando um ou ambos tiverem mais de 70 anos; ou casarem sem a observância das causas suspensivas; como também dependerem de suprimento judicial para casar — os nubentes não poderão dispor sobre o regime de bens, já que a lei impõe a estas uniões o regime de separação obrigatória.

Caso, contudo, ainda assim os nubentes estipulem cláusulas que violem normas cogentes, o artigo 1.655 do Código Civil determina que o pacto será nulo em sua integralidade ou apenas nas cláusulas infratoras:

“Trata-se de corolário do à regra geral contido no art. 166, VI, que dispõe ser nulo o negócio jurídico que tiver por objetivo fraudar lei imperativa.

A nulidade pode contaminar o pacto antenupcial em sua integralidade, ou apenas uma ou algumas de suas cláusulas. Se a eliminação da(s) cláusula(s) viciadas não comprometer o próprio pacto antenupcial, ele permanece válido quanto às demais cláusulas (art. 184)."

Desse modo, nos casos em que o pacto escolhido pelos nubentes for nulo - hipótese em que a vontade das partes será tida como não manifestada - ou que houver ausência da eleição de um regime de bens, vigorará o regime supletivo, qual seja a comunhão parcial de bens (artigo 1.640 do $\mathrm{CC})$.

\footnotetext{
${ }^{8}$ TEPEDINO, Gustavo et al.. Código Civil Interpretado: Conforme a Constituição da República, vol. IV. $1^{\text {a }}$ ed. Rio de Janeiro: Renovar, 2014. p. 258.

${ }^{9}$ Ibid, p. 292.
} 


\subsubsection{Comunhão Parcial}

Por ser aparentemente a opção mais justa, a comunhão parcial foi escolhida pelo legislador para ser o regime legal dispositivo, vigorando nos casos em que os nubentes não celebrarem pacto antenupcial ou quando o pacto for nulo ou ineficaz (artigo 1.640 do Código Civil). Por esse motivo, se os nubentes optarem por este regime não será necessária a elaboração de um pacto antenupcial e de seu respectivo registro, basta um simples termo no processo de habilitação para que seja válido.

Nas palavras de Maria Berenice, a comunhão parcial funciona nos seguintes moldes: "o que é meu é meu, o que é teu é teu e o que é nosso, metade de cada um"10. Isto porque, neste regime, há uma convivência de bens particulares e bens comuns, classificados, principalmente, em razão da data de celebração do casamento.

Os bens que se comunicam são chamados de bens comuns, pois pertencem a ambos cônjuges em partes iguais. Cada cônjuge tem direito a sua meação, que corresponde a metade do patrimônio do casal. Os artigos 1.658 e 1.660, I, do Código Civil determinam ser os bens comuns os adquiridos onerosamente durante a constância do casamento, cujo marco inicial é sua celebração.

Os bens particulares, por sua vez, são os excluídos da comunhão, pertencendo exclusivamente a cada um dos cônjuges e podem ser objeto de doações ou compra e venda entre os cônjuges (artigo 499 do Código Civil).

O Código Civil estabelece, em seu artigo 1.661, que o bem adquirido antes da celebração do casamento integra o patrimônio particular do cônjuge. Contudo, nem sempre resta claro o momento exato de sua aquisição, eis que, apesar de muitas vezes o título aquisitivo ser anterior ao casamento, sua aquisição efetiva só ocorre após a união. Diante disso, para saber se o bem integra ou não o patrimônio comum do casal, é preciso verificar a causa da aquisição.

\footnotetext{
${ }^{10}$ DIAS, Maria Berenice. Op. Cit., p. 315.
} 
Se a causa da aquisição for anterior ao casamento, como na aquisição por usucapião com justo título anterior ao casamento, o bem será incomunicável. Porém, se a causa é posterior ao casamento, o bem será comum ao casal, como ocorre na usucapião, quando a posse teve início antes do casamento, mas se projetou para depois da sua celebração, ocorrendo uma composse do bem pelos cônjuges.

Note-se que os bens ficam em comunhão, instituto diferente do condomínio:
"Não há propriamente um condomínio entre os cônjuges $e$ companheiros, regido pelas regras do direito das coisas, mas um estado de indivisão mais próximo daquilo que a doutrina estrangeira denomina manocomunhão. Cuida-se de um regime de propriedade coletiva onde se preserva a integridade da massa patrimonial [...] a inexistência de condomínio torna indisponível as cotas-partes ideais que não podem ser destacadas do todo, nem podem ser alienadas a terceiros."

O artigo 1.659 do Código Civil traz um rol de bens excluídos da comunhão. O primeiro inciso determina serem os bens particulares não apenas os que já pertenciam ao cônjuge antes do matrimônio, mas também os que sobrevierem a título gratuito, bem como os que forem adquiridos por sub-rogação:

\footnotetext{
"A lei prevê três tipos de bens que, malgrado adquiridos após o casamento, não se comunicam: a) os recebidos por liberalidade do alienante (doação e sucessão); b) os adquiridos ou sub-rogados no lugar destes; e c) os adquiridos com valores de alienação dos bens particulares (neste sentido, sub-rogados)." ${ }^{, 12}$
}

Os bens provenientes de herança ou doações serão incomunicáveis por determinação de lei. Caso, contudo, o doador ou testador transmiti-los em favor de ambos os cônjuges, os bens integrarão a massa dos bens comuns (artigos 1.659, I, e 1.660, III, do Código Civil).

\footnotetext{
${ }^{11}$ TUCCI, Cibele Pinheiro Marcal. Aspectos Patrimoniais do Direito de Família no Brasil. In: AZEVEDO, Álvaro Vilaça (Org.) Revista Nacional de Família e Sucessões. Porto Alegre: Magister, 2014. p.50.

${ }^{12}$ LỔBO, Paulo. Direito Civil: Famílias. $4^{\text {a }}$ ed. São Paulo: Saraiva, 2011. p. 344.
} 
A lei também exclui da comunhão os bens adquiridos com valores exclusivamente pertencentes a um dos cônjuges em sub-rogação aos bens particulares, ou seja, em sua substituição (artigo 1.659, II, do Código Civil).

Importante atentar para o fato de que, nesta hipótese, a regra da incomunicabilidade dos bens sub-rogados não se estende às benfeitorias realizadas em bens particulares, "eis que ao cônjuge é assegurado o direito à parcela do acréscimo em benfeitorias havidas no bem alheio (art. 1.660, IV), nem os frutos e rendas dos bens próprios, tais como juros e alugueis (art. 1.660, V) ${ }^{\prime 13}$.

Outro ponto polêmico em relação à sub-rogação é a hipótese em que o bem sub-rogado é mais valioso do que o alienado, de modo que, para adquirir o novo bem, o cônjuge utiliza não apenas bens próprios, mas também bens comuns. Para solucionar essa problemática, a doutrina se divide em duas correntes: (i) alguns autores, como Caio Mario da Silva Pereira e Rolf Madaleno, entendem que o bem integraria os bens particulares e comuns, na proporção da contribuição; (ii) a segunda corrente afirma que a integralidade do bem pertence ao patrimônio comum, sendo devida, porém, indenização ao patrimônio particular do cônjuge prejudicado.

Também estão excluídos do patrimônio comum as obrigações anteriores ao casamento e as provenientes de atos ilícitos, desde que não se revertam em proveito do casal (incisos "III" e "IV" do artigo 1.659 do Código Civil).

Em seguida, o inciso "V" exclui os bens de uso pessoal, livros e instrumentos de profissão em decorrência de sua pessoalidade e por serem bens inerentes à sobrevivência. O inciso é exemplificativo, estão abrangidos outros bens pessoais tais como roupas, celular e jóias.

Em relação às jóias, existe uma controvérsia: de um lado, autores como Maria Berenice Dias e Carlos Roberto Gonçalves defendem que, por alcançarem muitas vezes valores exorbitantes, seriam um investimento do

\footnotetext{
${ }^{13}$ TEPEDINO, Gustavo et al.. Código Civil Interpretado: Conforme a Constituição da República, vol. IV. $1^{\text {a }}$ ed. Rio de Janeiro: Renovar, 2014. p. 299.
} 
casal e, portanto, haveria comunicação; de outro, Paulo Lôbo acredita serem bens de uso pessoal, de modo que as jóias deveriam ser classificadas como bens particulares. Independentemente da corrente, é importante atentar para a origem do bem, se as jóias foram recebidas como um presente de um cônjuge para o outro, estamos diante de uma doação que integrará o patrimônio particular do cônjuge que as ganhou (artigo 1.659, I).

Os instrumentos da profissão e livro também geram polêmica, eis que muitas vezes são adquiridos com o esforço conjunto, razão pela qual Maria Berenice Dias defende que "ainda que cabível atribuir, quando da partilha, tais bens ao cônjuge que deles faz uso profissionalmente, necessário que haja compensação com bens outros" ${ }^{\prime 14}$.

São, ainda, bens particulares os proventos do trabalho pessoal de cada cônjuge e as pensões, meios-soldos, montepios e outras rendas semelhantes. Alguns autores consideram que esses últimos dois incisos cometem injustiças, na medida em que beneficiam o cônjuge que trabalha por contraprestação pecuniária em detrimento do cônjuge que converte as economia em patrimônio, comprometendo, assim, o equilíbrio da divisão das obrigações familiares.

No entanto, conforme ensinado por Gustavo Tepedino, Heloisa Barboza e Maria Celina Bodin de Moraes, os dois últimos incisos do artigo 1.659 devem ser lidos em conjunto com o artigo 1.660, V, do Código Civil. A partir da leitura conjunta dos dispositivos é possível observar que o salário só é incomunicável enquanto possuir a função de adimplir as despesas mensais, uma vez depositado em conta corrente ou em aplicações financeiros ele passa a integrar o patrimônio comum dos cônjuges:

\footnotetext{
"Isso ocorre quando esses proventos dão frutos, caso em que haverá comunicabilidade. A interpretação do art. 1.659, VI, deve ser feita em consonância com o art. 1660, V, ambos do CC. Cabe, portanto, a ressalva de que o que se exclui da comunhão é o direito à remuneração decorrente do trabalho pessoal, pois, no momento em que ela ingressa no mundo financeiro, perderá as características originais, transformando-se em bens
}

\footnotetext{
${ }^{14}$ DIAS, Maria Berenice. Manual de Direito das Famílias. $10^{\mathrm{a}} \mathrm{ed}$. São Paulo: Editora Revista dos Tribunais, 2015. p.317.
} 
adquiridos na constância da sociedade conjugal e, dependendo do regime, tornando-se comunicáveis."

O voto da Relatora Ministra Nancy Andrighi no julgamento do REsp. $n^{\circ} 1024169 / R S$, julgado em abril de 2010, vai além:

\begin{abstract}
"A interpretação harmônica dos arts. 1.659, inc. VI, e 1.660, inc. V, do CC/02, permite concluir que, os valores obtidos por qualquer um dos cônjuges, a título de retribuição pelo trabalho que desenvolvem, integram o patrimônio do casal tão logo percebidos. Isto é, tratando-se de percepção de salário, este ingressa mensalmente no patrimônio comum, prestigiando-se, dessa forma, o esforço comum"
\end{abstract}

Por fim, o artigo 1.660 do Código Civil lista como bens comuns os adquiridos por fato eventual, com ou sem o concurso de trabalho ou despesa anterior (artigo 1.660, II), tais como acessão (natural) ou prêmios, sorteios e benfeitorias (decorrente de ato humano).

Veja-se que a doutrina possui entendimento no sentido de que caso as regras da comunhão parcial sejam alteradas por meio de pacto antenupcial, "acrescentando ou suprimindo regras da comunhão, o regime será transformado e, dessa forma, não será mais o regime de comunhão parcial, segundo o modelo legal"16.

Tendo em vista a dificuldade de comprovação da aquisição dos bens móveis, já que muitas vezes são dispensadas formalidades, o Código Civil instaurou a presunção relativa de que, vigendo o regime da comunhão parcial, tais bens presumem-se adquiridos na constância do casamento, integrando, portanto, patrimônio comum (artigo 1.662).

Assim, havendo dúvida quanto à data da aquisição de determinado bem móvel, caso o bem integre o acervo particular de um dos cônjuges, cabe ao interessado provar que adquiriu o bem antes da celebração do casamento, "daí a necessidade de o pacto antenupcial descrever minuciosamente os bens móveis, sob pena de se reputarem comuns"17.

\footnotetext{
${ }^{15}$ TEPEDINO, Gustavo et al.. Op. Cit. p. 302-303.

${ }^{16}$ Ibid. p.299.

${ }^{17}$ PEREIRA, Caio Mário da Silva. Instituições de Direito Civil: Direito de Família, vol. V. $23^{\mathrm{a}}$ ed. Rio de Janeiro: Forense, 2015. p.253.
} 
Se, por um lado, os bens comuns podem ser administrado por qualquer um dos cônjuges; por outro, os bens particulares devem ser administrados pelo cônjuge proprietário, cabendo disposição diversa no pacto antenupcial. Paulo Lôbo faz a ressalva de que a norma contida no artigo 1.665 seria contraditória com o que dispõe o artigo 1.647 , I, do Código Civil ${ }^{18}$ :
"A norma do art. 1.665 do Código Civil é aparentemente contraditória com o que estabelece o art. 1.647, quanto ao poder de dispor dos bens particulares. $O$ art. 1.647, I, condiciona a alienação ou constituição de ônus real dos imóveis, inclusive os particulares, à autorização do outro cônjuge, salvo o suprimento judicial, se a recusa for injustificada. As duas normas hão de ser harmonizadas, de modo a que sejam lidas como se dissessem: o cônjuge proprietário pode dispor de seus bens imóveis particulares, havendo autorização do outro ou suprimento judicial."19

Na visão de Maria Berenice, o artigo só trataria dos bens móveis, já que os bens imóveis, ainda que particulares, dependeriam da concordância do outro cônjuge para serem alienados (artigo 1.647, I, do Código Civil).

Nessa perspectiva, as dívidas contraídas por um dos cônjuges na administração dos bens comuns obrigam o acervo comum e, se insuficientes, obrigarão também os bens particulares do cônjuge que os administra e aos do outro na medida do proveito que houver auferido (artigo 1.663, $\S 1^{\circ}$, do Código Civil).

Seguindo o mesmo raciocínio, pautado pelo princípio da solidariedade e mútua assistência, o artigo 1.664 do Código Civil estabelece que, quando contraídas pelo marido ou pela mulher, os bens comuns do casal só responderão pelas dívidas, despesas de administração e decorrentes de imposição legal se destinadas a atender aos encargos da família.

O dispositivo faz uma presunção relativa de que a dívida contraída por um dos cônjuges foi feita com o consentimento do outro e em benefício da

\footnotetext{
18 "Art. 1.665. A administração e a disposição dos bens constitutivos do patrimônio particular competem ao cônjuge proprietário, salvo convenção diversa em pacto antenupcial."

"Art. 1.647. Ressalvado o disposto no art. 1.648, nenhum dos cônjuges pode, sem autorização do outro, exceto no regime da separação absoluta: I - alienar ou gravar de ônus real os bens imóveis;" ${ }^{19}$ LÔBO, Paulo. Direito Civil: Famílias. $4{ }^{a}$ ed. São Paulo: Saraiva, 2011. p.350 .
} 
família. Porém, em caso de dúvidas quanto à sua causa, o cônjuge gestor deve provar que preenche os requisitos do artigo, sob pena de responder com seus bens particulares.

Por óbvio, as dívidas contraídas por qualquer dos cônjuges, oriundas da gestão de bens particulares e em seu benefício, obrigam tão somente a estes, não atingindo os bens comuns.

Ainda que a administração dos bens comuns possa ser exercida por qualquer um dos cônjuges, é necessária a anuência do casal para atos que impliquem em cessão do uso ou do gozo desses bens, a título gratuito.

Por fim, o parágrafo $3^{\circ}$ do artigo 1.663 do Código Civil determina que, em caso de má-administração dos bens comuns, pode o outro cônjuge provocar o juiz para que atribua a administração desses bens a apenas um dos consortes.

Observa-se que não foi por acaso que a lei elegeu a comunhão parcial como regime supletivo, a divisão do patrimônio em três massas parece ser a mais justa, pois privilegia o esforço comum, direto ou indireto, para construção do patrimônio familiar, bem como resguarda o patrimônio construído com esforço próprio, pelos cônjuges, antes do casamento.

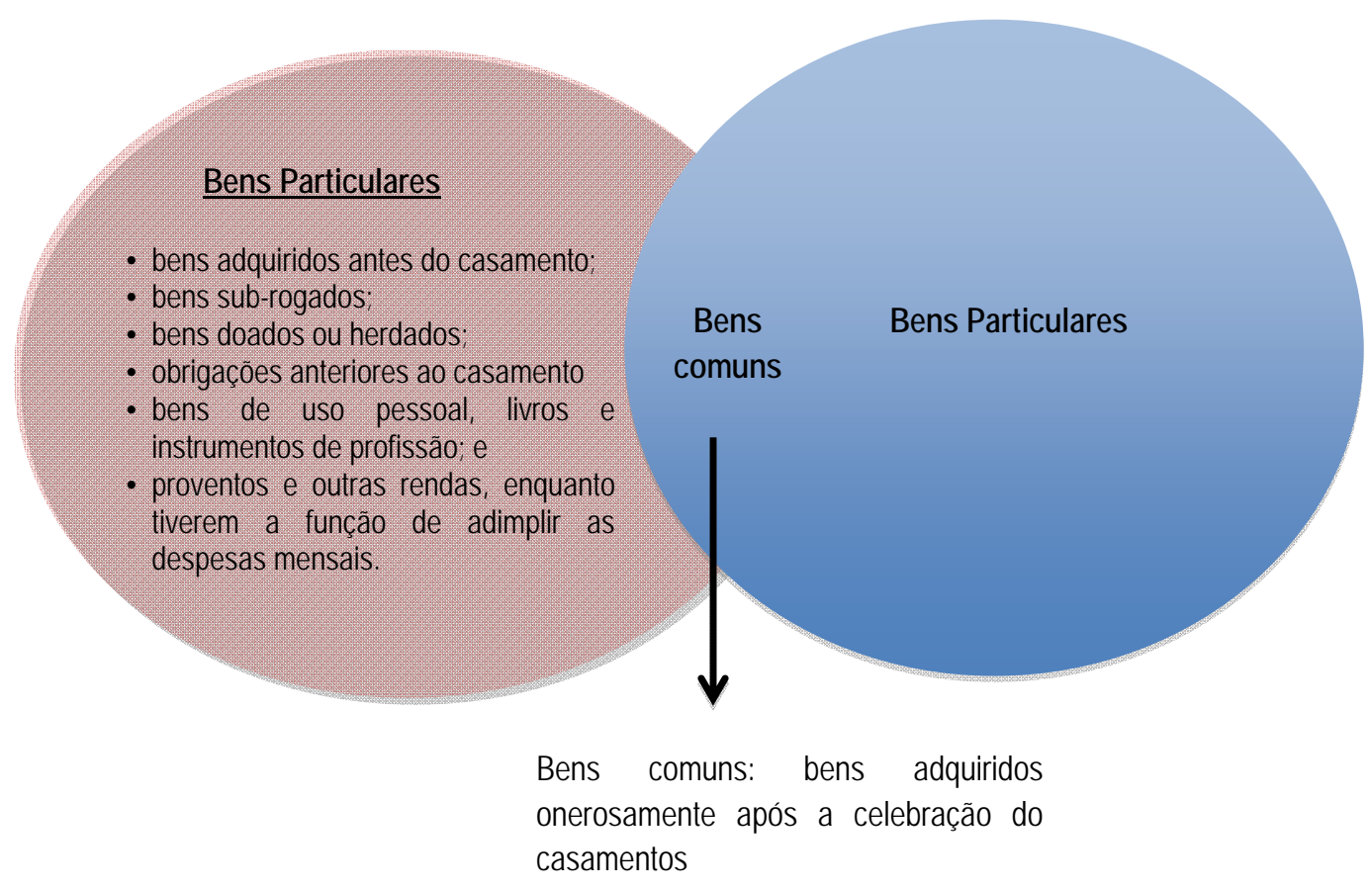




\subsubsection{Comunhão Universal}

Caracterizado pela comunhão de todos os bens presentes e futuros dos cônjuges (artigo 1.667 do Código Civil), inclusive dívidas passivas, a comunhão universal costumava ser o regime supletivo até o advento da Lei do Divórcio. Hoje, contudo, para adotar este regime é necessário a manifestação de vontade do casal por meio de pacto antenupcial.

Nas palavras de Pontes de Miranda, na comunhão universal "tudo que há e que entra para o acervo dos bens do casal fica indistintamente, como se fora possuído ou adquirido, ao meio, por cada um",20. No momento da aquisição do bem, durante a constância do casamento, ele automaticamente passa a integrar o acervo comum e cada cônjuge terá direito a metade do bem. A divisão dos bens entre os cônjuges só ocorre com a dissolução do casamento.

Maria Berenice ensina:

"Ocorre uma fusão entre os acervo entre os acervos trazidos para o matrimônio por qualquer dos nubentes, formando uma única universalidade, à qual se agrega tudo o que for adquirido, na constância do enlace conjugal, por qualquer dos cônjuges ,a título oneroso, por doação ou herança. Os patrimônios fundem em um só."21

Apesar de a regra na comunhão total ser a comunicação dos patrimônios, formando uma universalidade de bens comuns, o Código Civil permite algumas exceções, listadas no rol taxativo do artigo 1.668.

A primeira exceção prevista por lei são os bens doados ou herdados com cláusula de incomunicabilidade e os sub-rogados em seu lugar. Para que os bens façam parte do acervo particular de um dos cônjuges, o testador ou doador deve manifestar a sua vontade por meio da cláusula de incomunicabilidade. Assim, "em raciocínio inverso, não existindo cláusula de restrição à comunicação, os bens havidos por doação ou por herança

\footnotetext{
${ }^{20}$ MIRANDA, Pontes de. Tratado de Direito de Família: volume II. $3^{\text {a }}$ ed. São Paulo: Max Limonad, 1947. $208 \mathrm{p}$.

${ }^{21}$ DIAS, Maria Berenice. Manual de Direito das Famílias. 10aed. São Paulo: Editora Revista dos Tribunais, 2015. p.319.
} 
em nome de qualquer um dos cônjuges , se convivendo [...], ingressam na comunhão. "22

A mesma sorte se aplica aos bens adquiridos no lugar dos bens gravados com cláusula de incomunicabilidade, bem como ao produto da alienação desses bens.

Cabe, neste ponto, analisar outras hipóteses de incomunicabilidade como a cláusula de reversão, segundo a qual, com a morte do donatário, o bem doado retorna ao patrimônio do doador, não comunicando com o patrimônio do cônjuge daquele. E, ainda, os bens doados, legados ou herdados com cláusula de inalienabilidade serão incomunicáveis e impenhoráveis (artigo 1.911), nos termos do verbete da súmula n 49 do Supremo Tribunal Federal.

Em seguida, o inciso II estabelece que os bens gravados de fideicomisso e o direito do herdeiro fideicomissário, antes de realizada a condição suspensiva, também estão excluídos da comunhão.

O fideicomisso ocorre quando o testador, fideicomitente, dispõe expressamente em seu testamento que determinado bem será herdado ou legado pelo fiduciário, que terá a obrigação de, futuramente, por ocasião de sua morte, transcorrido certo tempo ou pelo implemento de determinada condição, transmiti-lo ao herdeiro fideicomissário (artigo 1.951).

Dessa forma, tendo em vista que o cônjuge fiduciário possui direito transitório, não ocorrerá a comunicação deste bem que deve ser transmitido para terceiro futuramente. Gustavo Tepedino, Heloisa Barboza e Maria Celina Bodin de Moraes explicam que "o fiduciário, enquanto não ocorre a transmissão, tem a propriedade restrita e resolúvel da herança ou do legado, [..] o que justifica a exclusão"23. E mais, "o fideicomissário, por

\footnotetext{
${ }^{22}$ MADALENO, Rolf. Curso de Direito de Família. $5^{\mathrm{a}}$ ed. Rio de Janeiro: Forense, 2013. p.781.

${ }^{23}$ TEPEDINO, Gustavo et al.. Código Civil Interpretado: Conforme a Constituição da República, vol. IV. $1^{\text {a }}$ ed. Rio de Janeiro: Renovar, 2014. p.319.
} 
sua vez, possui expectativa de direito, porque existe condição suspensiva ainda não implementada" 24 , o que não se comunicaria.

Também não se comunicam as dívidas anteriores ao casamento, salvo se provenientes dos gastos relativos ao seu preparativo e as que se reverterem em benefício comum. Em caso de dívidas decorrentes de ato ilícito praticado por um dos cônjuges, a doutrina se divide: alguns autores entendem que estas se comunicariam para conferir maior proteção à vítima; outros, como Rolf Madaleno acreditam que, em razão do caráter de pessoalidade das dívidas contraídas antes do casamento, ela pertenceria a quem cometeu o ato.

As doações antenupciais feitas de um cônjuge a outro com cláusula de incomunicabilidade também não se comunicam. Após o casamento, contudo, por serem comuns os bens, não cabe a doação entre cônjuges.

Assim como na comunhão parcial, o inciso V do artigo 1.668 do código Civil exclui da comunhão os (i) bens de uso pessoal, livros e instrumentos de profissão; (ii) os proventos do trabalho pessoal de cada cônjuge; e (iii) as pensões, meio-soldos, montepios e outras rendas semelhantes.

O Superior Tribunal de Justiça possui entendimento unânime no sentido de reconhecer, na comunhão total, que a indenização trabalhista integra a comunhão por ser considerada direito adquirido durante o tempo do casamento. No mais, aqui, aplicam-se as mesmas ressalvas comentadas anteriormente.

O artigo 1.669 do Código Civil faz uma ressalva quanto aos frutos provenientes dos bens excluídos da comunhão. Nos termos deste artigo, quando percebidos na constância do casamento, não se estende aos frutos a incomunicabilidade que atinge os bens listados no artigo 1.668 do mesmo diploma legal. Dessa forma, todos os frutos percebidos na vigência do casamento, ainda que provenientes de bens particulares, se comunicam.

\footnotetext{
${ }^{24}$ Ibid. p. 319.
} 
A administração dos bens na comunhão total segue as mesmas regras da comunhão parcial, acima comentadas (artigo 1.670 do Código Civil): em regra, os bens comuns são administrados por ambos e os raros bens particulares existentes na comunhão total são administrados por seus proprietários.

Por fim, a comunhão de bens se encerra com a dissolução da sociedade conjugal, que pode ocorrer em razão da morte de um dos cônjuges, pela anulação do casamento, pela separação judicial, restabelecendo a comunhão com a reconciliação ou com o divórcio. Finda a comunhão, os bens são partilhados e, homologada a partilha, cada um dos cônjuges ficará responsável pela próprias dívidas, conforme previsto pelo artigo 1.671 do Código Civil.

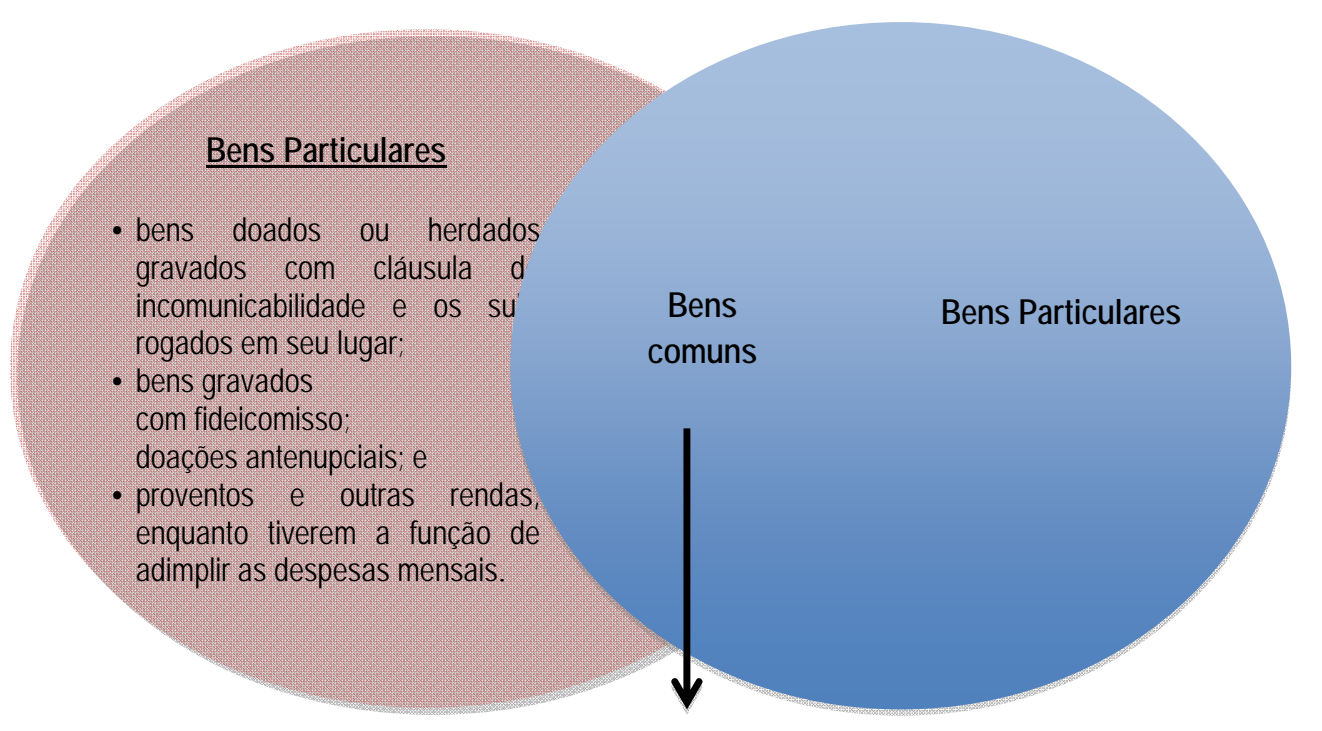

Bens comuns: comunicam todos os bens adquiridos por qualquer um dos cônjuges presentes, passados ou futuro e a qualquer título, onerosamente, por doação ou herança, desde que livre da cláusula de incomunicabilidade.

\subsubsection{Participação final nos aquestos}

A participação final nos aquestos foi uma inovação do Código Civil de 2002, inspirada no direito costumeiro húngaro. Utilizado como regime legal em diversos países, como Alemanha e Costa Rica, este regime está dividido em dois momentos: (i) o período da vigência do casamento; e (ii) o 
momento de sua dissolução, ainda que por morte (artigo 1.685). Nas palavras de Rolf Madaleno:

"A rigor, esse híbrido regime de participação diferida gera duas fases
bem distintas, sendo a primeira delas identificada com o regime da total
separação de bens e, por ocasião da dissolução da união, incidiria o
regime de comunhão parcial [...]."."

Como se vê, durante o casamento aplicam-se as regras da separação de bens, cada cônjuge possui patrimônio próprio composto por bens que se subdividem em dois grupos: (i) o patrimônio particular, quais sejam os bens que cada cônjuge possuía ao casar, ou os sub-rogados em seu lugar, os obtidos por sucessão ou liberalidades e as dívidas relativas a estes bens; e (ii) os bens por ele adquiridos onerosamente na constância do casamento (artigos 1.673 e 1674 do Código Civil).

A administração do patrimônio próprio é exercida exclusivamente pelo cônjuge proprietário, que possui total liberdade e independência para dispor dos bens móveis, sendo necessária a outorga do outro cônjuge apenas para alienação de bens imóveis, ainda que registrado apenas em nome de um dos consortes (artigos 1.647, I, e 1.673, parágrafo único, do Código Civil).

No entanto, a lei permite que o casal convencione a possibilidade de livre disposição do patrimônio particular no pacto antenupcial, dispensando-se, assim, a autorização do outro cônjuge (artigo 1.656 do Código Civil).

Com a dissolução do casamento, tem início a segunda fase, passa a vigorar as regras da comunhão parcial. Os bens comuns, adquiridos pelo esforço comum, mesmo que em nome de apenas um dos consortes, são divididos igualmente entre o casal (artigo 1.679 do Código Civil). Não sendo possível ou desaconselhável a sua divisão em natureza, esta ocorrerá pelo valor do bem, a fim de evitar o condomínio. E mais, se a reposição da quantia devida em dinheiro representar um obstáculo, devem ser avaliados e

\footnotetext{
${ }^{25}$ MADALENO, Rolf. Curso de Direito de Família. 5a ed. Rio de Janeiro: Forense, 2013. p. 802.
} 
alienados judicialmente tantos bens quanto forem necessários para alcançar o valor da meação (artigo 1.684 do Código Civil).

Já para amealhar os bens adquiridos onerosamente por cada um dos consortes é necessário apurar os haveres por meio de um balanço contábil e financeiro.

Em outras palavras, os bens adquiridos por cada cônjuge na constância do casamento, separados no patrimônio próprio de cada um, passam a se comunicar e deverão ser apurados e divididos.

A apuração de haveres deve ocorrer na data em que cessou a convivência, evitando, assim, manobras para desviar o acervo amealhado (artigo 1.683 do Código Civil).

Após a apuração de haveres, ocorre a compensação dos valores dos bens. Ou seja, os bens não são físicamente divididos, mas, a partir da apuração de seus valores, os bens permanecem no patrimônio do cônjuge proprietário e este deve compensar o outro consorte. Maria Helena ensina, "quando houver diferença de valores dos bens próprios, a reposição ao cônjuge não proprietário será feita em dinheiro. $\mathrm{Na}$ ausência do numerário, poderão ser alienados bens mediante a autorização judicial”26.

A participação, portanto, é feita sobre o valor dos incrementos patrimoniais e dividida por um sistema de compensação de créditos e não por condomínio ou comunhão.

A lei exclui da divisão os bens adquiridos antes do casamento e os sub-rogados em seu lugar, bem como os que sobrevieram a cada cônjuge por sucessão ou liberalidade e as dívidas relativa a estes bens, as quais são de responsabilidade exclusiva do titular do bem.

Em relação às dívidas contraídas na constância do casamento até a dissolução, se revertidas, parcial ou totalmente, em benefício do outro cônjuge, integrarão o passivo comum, de modo que marido e mulher são responsáveis por ela.

\footnotetext{
${ }^{26}$ DIAS, Maria Berenice. Manual de Direito das Famílias. $10^{\mathrm{a} e d . ~ S a ̃ o ~ P a u l o: ~ E d i t o r a ~ R e v i s t a ~ d o s ~}$ Tribunais, 2015. p.323.
} 
Caso, contudo, beneficiem apenas o cônjuge que as contraiu, apenas este responde por essas dívidas (artigo 1.677 do Código Civil). Quem contraiu a dívida deve comprovar que o fez em benefício da família. Esta é a única hipótese em que as dívidas contraídas por apenas um dos cônjuges atingirá o patrimônio comum. Portanto, as dívidas pessoais de um dos cônjuges, que não revertam em benefício da família e sejam superiores ao valor da sua meação, não obrigarão a meação do outro cônjuge ou de seus herdeiros (artigo 1.686 do Código Civil).

O Código Civil, em seu artigo 1.678, também prevê que, quando um cônjuge solver a dívida do outro com bem de seu patrimônio, o valor do pagamento deve ser atualizado e imputado, na data da dissolução, à meação do cônjuge devedor.

Observe-se que antes da dissolução existe apenas uma expectativa de meação para os cônjuges:

"Somente após a dissolução da sociedade conjugal é que serão apurados
os aquestos. Há, portanto, para o s cônjuges, uma expectativa de direito
à meação, subordinando a partilha, por ocasião da dissolução da
sociedade conjugal, a uma precisa e rigorosa verificação contábil"27

Por isso, não é permitido a qualquer um dos consortes renunciar, ceder ou penhorar a sua meação durante o casamento, já que o direito a meação só nasce com a dissolução da sociedade conjugal (artigo 1.682 do Código Civil).

Cabe ressaltar, ainda, que assim como na comunhão parcial, a lei faz uma presunção relativa de que os bens teriam sido adquiridos durante o casamento (artigo 1.674, parágrafo único, do Código Civil).

A lei também faz outras presunções quanto à titularidade de alguns bens: presumem-se, perante terceiro, propriedade do cônjuge devedor os bens móveis, já que mais fáceis de serem alcançados para garantir a dívida.

\footnotetext{
${ }^{27}$ TEPEDINO, Gustavo et al.. Código Civil Interpretado: Conforme a Constituição da República, vol. IV. $1^{\text {a }}$ ed. Rio de Janeiro: Renovar, 2014. p.325.
} 
A lei faz uma ressalva quanto aos bens de uso pessoal do outro cônjuge, que não estariam incluídos na presunção relativa do artigo (artigo 1.680).

Outra presunção da lei é quanto à propriedade dos bens imóveis, sendo de titularidade do cônjuge cujo nome constar no registro. Em caso de impugnação, cabe ao cônjuge proprietário provar que o bem é de sua propriedade exclusiva.

Quando forem feitas doações sem a necessária autorização do outro consorte, o cônjuge prejudicado ou seus herdeiros podem reivindicar o bem dado ou computar no montante partilhável o valor equivalente ao bem, à época da dissolução e não à da data da doação.

Muitos autores criticam a previsão legal de que o cônjuge prejudicado pode reivindicar, a qualquer tempo, o bem doado sem autorização do outro consorte, pois prejudicaria a esfera jurídica de terceiro, sem a verificação dos requisitos de fraude. Isto sem falar que o bem pertencia ao patrimônio próprio de um dos cônjuges e, à época da doação, o outro só tinha a expectativa de direito. Paulo Lôbo afirma que melhor seria se o legislador se limita-se à regra geral de nulidade do ato.

Além disso, a hipótese de doação por um dos cônjuges sem consentimento do outro enquadra-se nas previsões do artigo 1.649 do Código Civil, segundo o qual o ato é anulável, podendo ser arguida em até dois anos após a dissolução do casamento por meio de ação anulatória.

A fim de evitar ato fraudulento do cônjuge que vise reduzir a real meação de seu consorte, o Código Civil prevê, em seu artigo 1.676, que o cônjuge ou seus herdeiros podem reaver bens alienados em detrimento da meação ou, se preferirem, podem requerer que seja incorporado ao monte o valor desses bens.

O regime de participação final nos aquestos parte do pressuposto de que existe igualdade material entre homem e mulher (artigo 226, §5 $5^{\circ}$, da Constituição Federal). Diante disso, proporciona a vantagem da possibilidade de cada cônjuge manejar com mais liberdade a administração 
de seus pertences, sem, contudo, ignorar o patrimônio que foi construído com esforço conjunto.

Esse regime foi alvo de críticas por parte da doutrina brasileira não apenas por ser incompatível com a realidade brasileira, na qual apenas a minoria dos casais possuem patrimônio próprio e desempenham ambos atividades econômica, mas também por facilitar a ocorrência de fraudes em razão da dificuldade em se apurar os aquestos para posterior divisão.

\subsubsection{Separação Convencional de bens}

A separação total convencional se dá pela separação completa do patrimônio dos consortes. Neste regime, não há qualquer comunicação entre os patrimônios dos cônjuges, ou seja, os bens passados, presentes e futuros serão de titularidade exclusiva de cada um que os adquiriu.

Nesta lógica, os efeitos patrimoniais do casamento não se operam, razão pela qual não a que se falar em direito à meação ou à bens comuns. Sobre o regime de separação convencional de bens, Caio Mario da Silva Pereira explica:

"No regime de separação total de bens, cada um dos cônjuges conserva a posse e a propriedade dos bens que trouxer para o casamento, bem como dos que forem sub-rogados, e dos que cada um adquirir a qualquer título na constância do matrimônio, atendidas as condições do pacto antenupcial.,28

Tendo em vista que o patrimônio de cada cônjuge é constituído apenas por bens particulares, a administração dos bens é exercida exclusivamente pelo proprietário. Ao optar pela separação total, os consortes têm, inclusive, total liberdade para dispor sobre seus bens, inclusive alienar bens móveis e imóveis e gravá-los com ônus real sem a exigência da outorga do outro cônjuge.

\footnotetext{
${ }^{28}$ PEREIRA, Caio Mário da Silva. Instituições de Direito Civil: Direito de Família, vol. V. $23^{\mathrm{a}}$ ed. atualizado por Tânia da Silva Pereira. Rio de Janeiro: Forense, 2015. p.271.
} 
É permitido ao cônjuge proprietário confiar ao outro a administração de seus bens, caso em que este será responsável de acordo com o que dispõe o artigo 1.652. Ainda que o mandado seja tácito, a gestão do outro cônjuge será considerada contratual, podendo ser remunerado ou não. Se, mesmo após a revogação da procuração, o outro consorte continuar a administrar os bens contra a vontade do proprietário, aquele será compelido a restituí-los, bem como a prestar contas de sua gerência.

Com relação às dívidas adquiridas por cada cônjuge, estas são de sua responsabilidade exclusiva. Porém, como nos outros regimes de bens, se contraídas em prol da família, os cônjuges se obrigam solidariamente (artigo 1.644 do Código Civil).

Importante observar que a separação convencional difere da separação obrigatória: enquanto nesta é imposto aos cônjuges que se enquadram nas hipóteses da lei; naquela a separação é convencionada pelo casal em pacto antenupcial, firmado por livre autonomia da vontade.

Dessa forma, o Superior Tribunal de Justiça possui entendimento majoritário no sentido de que não há que se falar em aplicação da súmula ${ }^{\circ}$ $377^{29}$, editada pelo Supremo Tribunal Federal, ao regime da separação convencional, pois os cônjuges optaram pela separação em dois patrimônios (REsp. n ${ }^{\circ} 404.088 / \mathrm{RS}$ ).

Apesar disso, alguns tribunais e doutrinadores possuem posicionamento diverso. À guisa de exemplo, Maria Berenice entende que os mesmo motivos que levaram à implementação da referida súmula ao regime de separação obrigatória autorizariam sua aplicação ao regime convencional, eis que busca evitar o enriquecimento ilícito de um dos cônjuges quando o bens tiverem sido adquiridos com esforço conjunto ${ }^{30}$. E,

\footnotetext{
${ }^{29}$ Súmula n 377 do STF: "No regime de separação legal de bens, comunicam-se os adquiridos na constância do casamento."

30“"A presunção de comunicabilidade instituída pela Súmula 377 do STF, quanto aos matrimônios celebrados sob regime de separação legal, visa a evitar o enriquecimento sem causa de um do par. $\mathrm{O}$ esforço comum é presumido e decorre da existência de vida em comum, representada precipuamente pela solidariedade que deve unir o casal, bem como a presença em todos os momentos da convivência, sendo pouco significado avaliar a contribuição financeira de cada um. As mesmas razões estariam presentes no regime de separação convencional dos bens, o que
} 
ainda, o Ministro Antônio Carlos Ferreira decidiu, no Resp. no 1.008.864RJ de sua relatoria, no sentido de que os bens adquiridos na constância da união se comunicariam.

Ao optar pela separação total, os bens obtidos em conjunto pelo casal integram o patrimônio individual de cada cônjuge na proporção de sua contribuição, de modo que, não existindo um patrimônio comum, o bem fica em condomínio, aplicando-se as regras deste instituto (artigos 1.314 1.326 do Código Civil).

Independentemente da existência de dois patrimônios que não se comunicam, o Código Civil busca a conjunção de esforços para manter a família. Nessa perspectiva, ambos os cônjuges se obrigam, na proporção de seus rendimentos, a contribuir para as despesas do casal. Essa regra pode, contudo, ser relativizada ou até excluída em estipulação acordada no pacto antenupcial (artigo 1.688 do Código Civil).

\subsubsection{Separação obrigatória de bens}

Há, ainda, o regime da separação obrigatória que se impõe quando ocorrer uma das três hipóteses taxativas do artigo 1.641 do Código Civil. Nesse caso, o casal deixa de ser livre para estipular o regime de bens que se aplicará à união, de modo que, ainda que os nubentes celebrem um pacto antenupcial, este será nulo, prevalecendo a previsão legal.

Segundo Arnaldo Rizzardo, ao impor esse regime, o legislador busca "proteger os bens de cada cônjuge em certas situações, ou por motivos de ordem pública, ou como forma de punição por infringência a certos impedimentos de menor relevância”. ${ }^{31}$

No que concerne à administração e à disposição de bens, são aplicadas as mesmas regras da separação convencional, de modo que cada cônjuge

autoriza a divisão do patrimônio adquirido. (DIAS, Maria Berenice. Manual de Direito das Famílias. 10aed. São Paulo: Editora Revista dos Tribunais, 2015. p. 325-326)

${ }^{31}$ RIZZARDO, Arnaldo. Direito de Família. $6^{\mathrm{a}}$ ed. Rio de Janeiro: Forense, 2008. p. 660. 
administra seus bens próprios e pode, sem autorização do outro, praticar os atos previstos no artigo 1.647 do Código Civil, tais como alienar bens ou gravá-los com ônus reais.

A primeira hipótese prevista no artigo 1.641 do Código Civil em que se impõe a separação obrigatória é quando o casamento é celebrado com a inobservância das causas suspensivas previstas no artigo 1.523 do Código Civil. Ou seja, impõe-se o regime de separação legal ao casamento celebrado por:

(i) viúvo(a) que tiver filho do cônjuge falecido, enquanto não fizer inventário dos bens do casal e der partilha aos herdeiros;

(ii) viúva, ou a mulher cujo casamento se desfez por ser nulo ou ter sido anulado, até dez meses depois do começo da viuvez, ou da dissolução da sociedade conjugal;

(iii) divorciado, enquanto não houver sido homologada ou decidida a partilha dos bens do casal; ou

(iv) tutor ou o curador com os seus descendentes, ascendentes, irmãos, cunhados ou sobrinhos, com a pessoa tutelada ou curatelada, enquanto não cessar a tutela ou curatela, e não estiverem saldadas as respectivas contas.

O parágrafo único do artigo 1.523 do Código Civil faz a ressalva de que, em sendo as hipóteses (i), (iii) ou (iv), os nubentes podem provar que não há prejuízo ao herdeiro, ex-cônjuge ou pessoa tutelada ou curatela, respectivamente, e obter autorização judicial para que não lhes sejam aplicadas as causas suspensivas. Nesse caso, deferido judicialmente, os nubentes poderão optar por qualquer regime de bens.

No que tange à hipótese (ii), provado na fluência do prazo o nascimento do filho ou a inexistência de gravidez, os nubentes ficam livres da causa suspensiva e também poderão eleger qualquer regime de bens que melhor lhes aprouver.

Esclareça-se que, nos casos em que são inobservadas as causas suspensivas, o legislador buscou "evitar a confusão patrimonial, da qual 
poderia advir danos financeiros a herdeiros ou a ex-cônjuges"32. Apesar disso, Maria Berenice afirma que "o dispositivo tem clara conotação punitiva, pois atribui apenação a quem desobedece a mero capricho legal"33.

Em seguida, o artigo 1.641 do Código Civil prevê que em casamentos nos quais um dos nubentes ou ambos sejam maiores de 70 (setenta) anos, deverá incidir o regime da separação obrigatória. Antes a lei previa a idade de 60 (sessenta) anos, mas a Lei n ${ }^{\circ}$ 12.344/2010 aumentou a idade para 70 (setenta) anos.

A maior parte da doutrina considera este dispositivo discriminatório e inconstitucional, pois viola princípios constitucionais de igualdade, liberdade e dignidade humana, impondo uma "interdição compulsória"34.

Maria Berenice critica o regime de separação legal, ao afirmar que " $a$ limitação, além de odiosa, é inconstitucional „35. No mesmo sentido, Rolf Madaleno explica:

“[...] por se tratar de um dispositivo com claro propósito de limitação da capacidade das pessoas, sem qualquer avaliação acerca do discernimento do nubente septuagenário, destituído de defesa $e$ argumentação, para simplesmente considerá-lo inapto para exteriorizar seus sentimentos através de um casamento sem imposições nascidas da suposição de quem dele se aproxima afetivamente o faz com propósitos exclusivamente materiais" ${ }^{36}$.

Seguindo esta linha de pensamento, Caio Mario da Silva Pereira ataca a decisão do legislador, ao afirmar que a regra "não encontra justificativa econômica ou moral, pois que a desconfiança contra o casamento dessas pessoas não tem razão para subsistir,"37.

\footnotetext{
${ }^{32}$ TEPEDINO, Gustavo et al.. Código Civil Interpretado: Conforme a Constituição da República, vol. IV. $1^{\text {a }}$ ed. Rio de Janeiro: Renovar, 2014. p. 266.

${ }^{33}$ DIAS, Maria Berenice. Art. 1641: inconstitucionais limitações ao direito de amar. Disponível em:http://www.mariaberenice.com.br/uploads/1 art. 1641_inconstitucionais_limita\%E7\%F5es ao direito de amar.pdf Acessado em 20.06.2015

${ }^{34}$ TEPEDINO, Gustavo et al.. Op. Cit, p. 267.

${ }^{35}$ DIAS, Maria Berenice. Op. Cit.

${ }^{36}$ MADALENO, Rolf. Curso de Direito de Família. 5a ed. Rio de Janeiro: Forense, 2013. p. 736.

${ }^{37}$ PEREIRA, Caio Mário da Silva. Instituições de Direito Civil: Direito de Família, vol. V. $23^{\mathrm{a}}$ ed. atualizado por Tânia da Silva Pereira. Rio de Janeiro: Forense, 2015. p. 225.
} 
E pior: esta é a única hipótese em que a obrigatoriedade do regime de separação total não pode ser contornada. A doutrina, no entanto, defende o direito do idoso de obter o "perdão" para que possa celebrar pacto antenupcial válido, sob o argumento de que esta previsão "não protege o idoso, mas seus herdeiros, tendo feição estritamente patrimonialista, na contramão da tendência do Direito Privado contemporâneo, de proteger a pessoa humana" 38

Por fim, a terceira hipótese de imposição da separação legal se dá quando o casamento depender de suprimento judicial, como ocorre com os nubentes que ainda não alcançaram a idade núbil, ou se foi denegada a autorização do representante legal (artigos 1.517 e 1.519 do Código Civil). Esse dispositivo tem por objetivo evitar o enriquecimento de um nubente ambicioso.

Não há muita lógica em impor o regime de separação legal aos casos em que a autorização para casar veio do próprio Estado, confirmando que a negativa dos genitores foi injustificada. Por isso, Maria Berenice diz que "acabaram sendo punidos os noivos por resistência descabida dos genitores em concordar com as núpcias" 39 .

Fato é que, uma vez alcançada a idade núbil, os cônjuges podem pedir a alteração do regime para o que melhor lhes aprouver, já que a causa que gerou a imposição da separação obrigatória terá cessado.

A fim de dirimir as controvérsias que surgiram acerca do regime de separação obrigatória, em 1964 o Supremo Tribunal Federal editou a súmula $\mathrm{n}^{\mathrm{o}} 377$, que autorizou a comunhão dos bens adquiridos na constância do casamento sob o regime da separação legal. Paulo Lôbo explica os efeitos práticos da súmula:

“Em seus efeitos práticos, a Súmula converte o regime legal de separação em regime de comunhão parcial, sem excluir os bens adquiridos por

\footnotetext{
${ }^{38}$ TARTUCE, Flávio. Manual de Direito Civil: volume único. $5^{\circ}$ ed. São Paulo: Método, 2015. p. 1.171 .

${ }^{39}$ DIAS, Maria Berenice. Manual de Direito das Famílias. 10ªed. São Paulo: Editora Revista dos Tribunais, 2015. p. 328.
} 
doação ou testamento. A separação patrimonial fica adstrita aos bens adquiridos antes do casamento." 40

Contudo, com a vigência da Constituição Federal de 1988 e do Código Civil de 2002 surgiram novas polêmicas. Parte da doutrina entendeu que, com o novo Código Civil, a súmula perdeu a eficácia, já que a redação do novo artigo era diferente daquela do artigo 259 do Código Civil de $1916^{41}$, que ensejou a edição da súmula. Em sentido contrário, alguns autores afirmaram que, a despeito da revogação do artigo 259, com base em princípios constitucionais e norteadores do Direito de Família, tais como a solidariedade, enriquecimento sem causa e mútua assistência, a súmula $\mathrm{n}^{\circ}$ 377 deveria continuar em vigor.

O próprio Superior Tribunal de Justiça mostrou-se dividido, eis que, ao longo dos anos, não apresentou jurisprudência uníssona quanto à aplicação da súmula n ${ }^{\circ} 377$.

Apesar do embasamento legal da súmula $n^{\circ} 377$ ser em um artigo do Código Civil de 1916 que já não está mais em vigor, me parece acertada a aplicação da súmula. Isto porque, amenizaria os efeitos do regime de separação obrigatória que, em muitos aspectos, se mostra inconstitucional.

Outro debate que se instaurou foi quanto à necessidade de provar a ocorrência de esforço comum na aquisição dos bens. Atualmente, o entendimento majoritário é no sentido de que se presume o esforço comum, não sendo necessário prová-lo. No entanto, recentemente o Superior Tribunal de Justiça proferiu decisão no sentido de que a partilha do patrimônio de casal que vive em união estável mantida sob o regime da separação obrigatória não é mais automática. Agora, na divisão daquilo que foi adquirido onerosamente na constância da relação, cada convivente tem que provar que contribuiu "com dinheiro ou esforço" para a aquisição dos

\footnotetext{
${ }^{40}$ LÔBO, Paulo. Direito Civil: Famílias. $4^{\text {a }}$ ed. São Paulo: Saraiva, 2011. p. 327.

${ }^{41}$ Art. 259. Embora o regime não seja o da comunhão de bens, prevalecerão, no silêncio do contrato, os princípios dela, quanto à comunicação dos adquiridos na constância do casamento.
} 
bens $^{42}$. Essa decisão foi proferida pela Segunda Secção do Superior Tribunal de Justiça, do qual foi relator o Ministro Raul Araújo.

Esse entendimento parece equilibrar o sistema legal do Código Civil com a súmula $n^{\circ} 377$, prestigiando ora a eficácia do regime da separação obrigatória e, quando cabível, o esforço comum. Assim, a súmula $n^{\circ} 377$ do STF só será aplicada quando comprovado o esforço comum, nos demais casos vale o previsto no Código Civil.

Apesar de toda polêmica, o entendimento majoritário é no sentido de aplicar a súmula $n^{0} 377$ do Supremo Tribunal de Justiça, de modo que os bens adquiridos onerosamente na constância do casamento se comunicam.

Com o intuito de amenizar as injustiças cometidas pelo artigo 1.641 do Código Civil, Maria Berenice propõe duas soluções: a união estável, já que as causas suspensivas não impedem o seu reconhecimento (artigo $1.723, \S 2^{\circ}$ ), ou por livre comunicação por meio de doações. Vejamos:

\begin{abstract}
"As limitações impostas à vontade dos noivos torna mais vantajosa a união informal. Diante da vedação à livre eleição do regime de bens, a solução mais lógica é simplesmente abandonar a ideia de sacramentar a união pelo casamento. Mas, como persiste o desejo de constituição de família, para afastar as restrições legais, o jeito é viver em união estável, pois não vigoram quaisquer impedimentos. [...]

As doações entre os cônjuges também são mecanismo hábil para livre comunicação de bens. Sob fundamento de serem vedadas somente doações por meio de pacto antenupcial, tais atos de liberalidade vêm sendo respeitados pela jurisprudência, ainda quando teve vigência o regime de separação legal de bens." ${ }^{43}$
\end{abstract}

Por fim, merece destaque o Projeto de Lei no 2.285/2007 (anexo I), conhecido como "Estatuto das Famílias", de iniciativa do IBDFAM, ainda em trâmite no Congresso Nacional, que, dentre seus objetivos, busca suprimir o regime de separação compulsória, ao deixar de prevê-lo na seção dos regimes de bens (Seção IV).

\footnotetext{
42،"Partilha de bens em união estável no regime de separação obrigatória exige prova de esforço comum". Disponível em http://www.stj.jus.br/sites/STJ/default/pt_BR/noticias/noticias/Partilhade-bens-em-uni\%C3\%A3o-est \%C3\%A1vel-no-regime-de-separa\%C3\%A7\%C3\%АЗ obrigat \%C3\%B3ria-exige-prova-de-esfor\%C3\%A7o-comum Acessado em 15.09.2015.

${ }^{43}$ DIAS, Maria Berenice. Art. 1641: inconstitucionais limitações ao direito de amar. Disponível em:http://www.mariaberenice.com.br/uploads/1 art.1641_inconstitucionais_limita\%E7\%F5es ao_direito_de_amar.pdf Acessado em 20.06.2015.
} 


\subsection{A UNIÃO ESTÁVEL}

Nas palavras de Maria Berenice, "a união estável nasce da convivência, simples fato jurídico que evolui para a constituição de ato jurídico, em face dos direitos dessa relação" ${ }^{\text {"44. }}$

Reconhecida pela Constituição Federal como entidade familiar, em seu artigo $226, \S 3^{\circ}$, a união estável, que antes era regulamentada pelo direito obrigacional, passou a ser matéria de família, surgindo para o companheiro o direito à meação do patrimônio com fundamento no princípio da solidariedade.

O Código Civil determinou como requisitos da união estável a convivência pública, continua e duradoura do casal, estabelecida com o objetivo de constituição de família. Como observa Flávio Tartuce, são expressões "abertas e genéricas, de acordo com o sistema adotado pela atual codificação privada, demandando a análise caso a caso" ${ }^{\text {"45 }}$.

A lei não estipula um tempo mínimo para que se caracterize a união estável, bem como não exige que o casal viva sob o mesmo teto. O intuito da lei é que os casal conviva como se possuísse "posse de estado de casado". Ou seja, o casal deve possuir o ânimo de "gerar a convicção de que podem marchar para relação matrimonial"46, dividindo responsabilidades e participando um da vida financeira do outro.

Note-se que à união estável não se aplicam as causas suspensivas do casamento (artigo 1.723, $\S 2^{\circ}$ ). Contudo, existe um debate polêmico quanto à imposição ou não do regime de separação legal à união estável na hipótese em que pelo menos um dos companheiros tenha mais de 70 (setenta) anos.

\footnotetext{
${ }^{44}$ DIAS, Maria Berenice. Manual de Direito das Famílias. 10aed. São Paulo: Editora Revista dos Tribunais, 2015. p.241.

${ }^{45}$ TARTUCE, Flávio. Manual de Direito Civil: volume único. $5^{\circ}$ ed. São Paulo: Método, 2015. p. 1237.

${ }^{46}$ PEREIRA, Caio Mário da Silva. Instituições de Direito Civil: Direito de Família, vol. V. $23^{\mathrm{a}}$ ed. atualizado por Tânia da Silva Pereira. Rio de Janeiro: Forense, 2015. p.656.
} 
Se, por um lado, alguns autores, como Maria Berenice, entendem que não seria aplicável o artigo 1.641, II, do Código Civil, por não caber interpretação analógica para restringir direitos; por outro, Caio Mario da Silva Pereira argumenta no sentido de que deveria ser aplicado, sob pena de conferir um tratamento privilegiado aos companheiros em detrimento dos casamento chancelado pelo Estado.

Em nosso ordenamento jurídico existem várias situações em que ao cônjuge e ao companheiro são destinados tratamentos distintos. Apesar de considerar inconstitucional essa distinção, neste caso específico acho que não cabe a interpretação analógica para restringir a liberdade dos companheiros, já que o próprio regime de separação obrigatória, mesmo quando aplicado ao casamento, se mostra inconstitucional em vários aspectos.

Assim como no casamento, os companheiros podem estipular livremente sobre o regime de bens que melhor os aprouver. Para tanto, é necessário a celebração de um pacto de convivência, que nada mais é do que um contrato sobre regime de bens. Este pacto pode regular questões existências nos mesmos moldes e limites do pacto antenupcial. Pode, também, ser alterado para mudar o regime de bens a qualquer tempo, sem necessidade de autorização judicial, desde que não haja prejuízo a terceiros.

A lei exige apenas que o pacto de convivência seja escrito, não exige instrumento público para sua validade, podendo ser feito, inclusive, por instrumento particular. No entanto, sem qualquer embasamento legal, existem provimentos de vários tribunais que só admitem o contrato quando levado a registro, no Cartório de Registro de Títulos e Documentos.

$\mathrm{Na}$ ausência de convenção quanto ao regime de bens, as relações patrimoniais dos companheiros serão regidas pelo regime da comunhão parcial, no que couber (artigo 1.725 do Código Civil).

Tendo em vista que a lei faz a ressalva de que se aplicam as regras da comunhão parcial à união estável "no que couber", surge a polêmica quanto à aplicação das limitações previstas pelo artigo 1.647 do Código Civil às 
relações entre companheiros. $\mathrm{O}$ artigo exige a autorização do outro cônjuge para atos que impliquem disposição de bens, tais como alienação de bens imóveis.

Majoritariamente, a doutrina entende que é necessária a autorização do outro companheiro, eis que, por não ser um ato solene, a união estável não gera mudança no estado civil dos companheiros, bem como não há qualquer previsão legal que obrigue o registro dos bens comuns em nome de ambos os companheiros. Assim, a outorga do companheiro garantiria maior segurança.

Em outras palavras, não há no cartório de registro de imóveis qualquer informação quanto ao alienante possuir ou não um companheiro. Isto gera insegurança aos interesses de terceiros de boa-fé, pois pode ocorrer de um dos companheiros alienar unilateralmente um bem imóvel, em prejuízo à meação do outro, omitindo o seu estado concubinário. Nesse caso, para não prejudicar o terceiro de boa-fé, ao invés de tornar nulo o ato, "é assegurado ao companheiro o direito indenizatório a ser buscado contra o parceiro"47.

A exigência de autorização para prática desses atos de disposição protegeria o companheiro e o terceiro de boa-fé de situações ilícitas.

Apesar disso, há quem discorde da exigência de autorização. Gustavo Tepedino, Heloiza Barbosa e Maria Celina Bodin de Moraes entendem que os efeitos jurídicos decorrentes do casamento não podem ser aplicados à união estável, pois a razão da norma difere quanto às entidades familiares. Dessa forma, para ele não seria razoável exigir a outorga do companheiro para prática desses atos, sendo devida composição em perdas e danos quando a alienação ocorrer em prejuízo de um dos companheiros.

No mais, aplicam-se as mesmas disposições que na comunhão parcial de bens, já analisadas, "os bens adquiridos a título oneroso na constância

\footnotetext{
${ }^{47}$ DIAS, Maria Berenice. Manual de Direito das Famílias. $10^{\mathrm{a}}$ ed. São Paulo: Editora Revista dos Tribunais, 2015. p.254.
} 
da união estável pertencem a ambos os companheiros, devendo ser partilhados, em caso de dissolução" 48 .

Um dos grandes obstáculos quanto à aplicação dos efeitos patrimoniais da união estável é o seu reconhecimento pelo Estado. Quando um dos companheiros não quiser reconhecer voluntariamente a união, $\mathrm{o}$ outro deve ajuizar ação de reconhecimento de união estável, cuja sentença é meramente declaratória para reconhecer a existência da relação e identificar o período de convivência em face dos efeitos patrimoniais.

Por não ser um ato solene, quando não for firmado um pacto de convivência e o casal não tiver filhos, o companheiro pode encontrar dificuldades em provar a sua existência.

\subsection{PARTILHA DE BENS}

Com a dissolução do casamento ou da união estável, a comunhão também deve ser encerrada. Para tanto, os bens, dívidas e encargos comuns devem ser divididos. Ou seja, só será necessária a partilha nos regimes de bens em que haja comunicabilidade de patrimônios, o que não ocorre quando o regime em vigor for o da separação convencional, pois já existem dois patrimônios distintos.

A partilha pode ser feita por proposta dos cônjuges, hipótese em que será necessária a homologação judicial, ou decidida pelo juiz. No entanto, o juiz pode recusar-se a homologar a partilha ao verificar que esta causa relevante prejuízo a uma das partes, não atendendo aos seus interesses. Essa avaliação que juiz deve fazer para saber se a partilha está equilibrada antes de homologá-la é conhecida como "cláusula de dureza" (artigo 1.574, parágrafo único, do Código Civil).

\footnotetext{
${ }^{48}$ GONÇALVES, Carlos Roberto. Direito Civil Brasileiro: Direito de Família, vol. VI. $6^{\text {a }}$ ed. São Paulo: Saraiva, 2009. p. 572.
} 
Já na união estável, a fím de atender a interesses recíprocos e de terceiros, os companheiros devem desfazer "a comunhão de vida e de bens através de escritura, pública ou particular, que independe de homologação judicial para produzir efeitos" $" 49$. Porém, ocorrendo de forma litigiosa, é necessário o ajuizamento de ação para identificar o período de convívio e amealhar os bens, nesse caso também se faz necessária a homologação judicial.

A regra é a da meação, isto é, o patrimônio comum deve ser dividido em metades iguais, sendo cada um dos ex-cônjuges titular de uma delas. Se a divisão for feita desigualmente, e ambas as partes concordarem, aquilo que exceder a metade será considerado excesso de um cônjuge para o outro, sujeita ao pagamento do imposto de transmissão.

A separação de fato sinaliza o fim da união e, principalmente, o fim da comunhão de bens. A partir do fim da convivência até a realização da partilha, os bens comuns ficam em condomínio entre os ex-cônjuges, de modo que os dois têm direito a posse e uso.

Ocorre que, muitas vezes, os bens ficam na posse de somente um dos ex-consortes, ensejando o direito de crédito pelo uso exclusivo, caso contrário ocorreria enriquecimento ilícito.

Em relação ao imóvel comum que serve de moradia para a família, o ideal seria a venda deste imóvel para aquisição de outros dois, um para cada ex-cônjuge. Contudo, não sendo possível, a divisão deve ser postergada até que um dos cônjuges consiga alugar ou adquirir outro imóvel.

Neste caso, o cônjuge que ficar com a posse exclusiva do imóvel deve pagar metade do valor correspondente ao aluguel do imóvel para o outro. Essa quantia tem caráter indenizatório, e não de aluguel. Existem três posições quanto ao momento inicial do pagamento, o Superior Tribunal Federal majoritariamente entende que deve começar a partir da citação, outro julgados determinam que o pagamento deve ser feito após o decreto

\footnotetext{
${ }^{49}$ TEPEDINO, Gustavo et al.. Código Civil Interpretado: Conforme a Constituição da República, vol. IV. $1^{a}$ ed. Rio de Janeiro: Renovar, 2014. p. 435.
} 
de partilha. Uma terceira corrente minoritária entende que o marco inicial é a separação de fato.

Veja-se que se a posse do imóvel permanecer com quem faz jus a alimentos, não cabe a imposição da indenização, pois configura alimentos in natura.

Na partilha de bens móveis, o ex-cônjuge que ficar com o bem deve pagar ao outro metade de seu valor, calculado a época da separação de fato, com atualizações.

O patrimônio a ser dividido corresponde ao produto da subtração do ativo menos o passivo. Se, por exemplo, um bem foi adquirido à prestação, só será partilhado o valor correspondente às prestações que já foram pagas durante o casamento.

Seguindo a mesma lógica, os ativos financeiros também devem ser partilhados pela metade. Quando o casal possui conta conjunta, tanto os ativos, como os passivos deve ser partilhados.

Enfim, o patrimônio comum deve ser dividido pela metade. Caso um dos ex-cônjuges fique sozinho com a posse de um dos bens comuns, este deve ao outro uma indenização pelo uso exclusivo da coisa.

\subsection{CASAR OU NÃO CASAR? E SOB QUAL REGIME?}

Como bem observa Cibele Tucci, "o regime de bens do casamento não deixa de ser uma forma de aquisição da propriedade" ${ }^{\natural 0}$. Para entender qual é o regime de bens que possibilita o maior enriquecimento patrimonial, após a dissolução do casamento ou da união estável, é necessário refletir sobre algumas situações.

Analisados todos os regimes de bens, conclui-se, por óbvio, que a comunhão total é o mais vantajoso em casamentos nos quais há grande

\footnotetext{
${ }^{50}$ TUCCI, Cibele Pinheiro Marcal. Aspectos Patrimoniais do Direito de Família no Brasil. In: AZEVEDO, Álvaro Vilaça (Org.) Revista Nacional de Família e Sucessões. Porto Alegre: Magister, 2014. p.41.
} 
discrepância ente os acervos individuais dos cônjuges, já que se comunicam os bens adquiridos, a qualquer título, antes e após o casamento, ainda que provenientes de doações e herança.

Vale lembrar, contudo, que a comunhão total só será aplicada à união se o casal celebrar pacto antenupcial ou de convivência, elegendo este regime.

No entanto, pode ocorrer que, no momento da escolha do pacto antenupcial, o cônjuge com maior patrimônio opte pelo regime da separação total. Nesse caso, para evitar a separação total de acervos, é mais vantajoso para a outra parte manter união estável informal, pois o regime que vigorará será o da comunhão parcial, comunicando-se, ao menos, os bens adquiridos onerosamente durante o convívio.

Porém, por ser um fato jurídico não solene, a união estável apresenta como obstáculo o reconhecimento da sua existência. Para que produza efeitos é necessário o ajuizamento de uma ação de reconhecimento e a sua comprovação.

Além disso, segundo Maria Berenice, a união estável também pode ser mais interessante nos casos em que a lei impõe separação compulsória. Isto porque, não se aplicam as causas impeditivas previstas para o casamento à união estável. Sendo assim, os companheiros poderiam fazer uma "lavratura de escritura publica constitutiva da união estável, em que podem livremente ser feitas estipulações de aspectos patrimoniais sem qualquer afronta à normatização jurídica" ${ }^{, 51}$.

Cabe ressalvar, nesse ponto, que a doutrina não possui posicionamento unânime quanto à imposição ou não do regime da separação obrigatória à união estável de maiores de setenta anos

Observe-se, ainda, que não cabe analisar, aqui, o regime de participação final nos aquestos, não apenas por ser pouco utilizado, mas,

\footnotetext{
${ }^{51}$ DIAS, Maria Berenice. Art. 1641: inconstitucionais limitações ao direito de amar. Disponível em:http://www.mariaberenice.com.br/uploads/1 art. 1641 inconstitucionais limita\%E7\%F5es _ao_direito_de_amar.pdf Acessado em 20.06.2015
} 
sobretudo, porque, com a dissolução do casamento, aplicam-se as mesmas regras da comunhão parcial.

Pelo exposto, quando não for possível ou desejada por uma das partes a estipulação da comunhão total, a parte interessada deve buscar saídas para evitar a implementação da separação absoluta, ainda que mantenha uma união informal, vigorando a comunhão parcial. Quanto menor a comunicação de bens, menores são as possibilidades de enriquecimento patrimonial do outro cônjuge. 


\subsection{LINHAS GERAIS DO DIREITO DAS SUCESSÕES E A RESERVA HEREDITÁRIA}

Nos termos do artigo 1.786 do Código Civil, a sucessão causa mortis ocorre em virtude da lei ou por disposição de última vontade prevista em testamento. Esta, chamada de sucessão testamentária, se baseia nos princípios da autonomia da vontade, livre iniciativa e propriedade privada (artigos $5^{\circ}$, XXII, XXIII e $1^{\circ}$, IV, da Constituição Federal). Já aquela, que nasce da lei, atendendo aos princípios da solidariedade e dignidade da pessoa humana, recebe o nome de sucessão legítima (artigos $1^{\circ}$, III; $3^{\circ}$, I; $5^{\circ}$, XXX; e 226 da Constituição Federal).

Assim, nas palavras de Mario Roberto, "a sucessão legítima é o testamento dos que não fizeram disposições de última vontade",52, já que ocorre quando não houver testamento, se este caducar, for julgado nulo ou não dispor sobre todos os bens inventariados.

Seguindo a mesma lógica, são chamados de sucessores legítimos aqueles que a lei prevê como herdeiros, os quais podem ser classificados como herdeiros necessários ou facultativos. Nos termos do artigo 1.845 do Código Civil, são herdeiros necessários os descendentes, ascendentes e o cônjuge (artigo 1.845 do Código Civil), a eles é garantido o direito a metade dos bens do patrimônio do de cujus, quota esta denominada legítima (artigo 1.789 do Código Civil).

Nesse contexto, tendo em vista que a lei prevê obrigatoriamente e de pleno o direito a legítima, os herdeiros necessários só serão privados de seu direito em situações taxativas por ela previstas, tais como a indignidade e a deserdação.

\footnotetext{
${ }^{52}$ FARIA, Mario Roberto Carvalho de. Direito das Sucessões: teoria e prática. $7^{\text {a }}$ ed. Rio de Janeiro: Forense, 2013. p. 91.
} 
Por sua vez, o herdeiro facultativo pode ser afastado da sucessão "mediante disposição de última vontade do autor da herança, bastando para tanto que não o contemple no testamento. Sua participação na sucessão, diferentemente do herdeiro necessário, não é obrigatória"53 (artigo 1.850 do Código Civil). Em outras palavras, os herdeiros facultativos possuem mera expectativa de direito, "herdam se não existirem herdeiros necessários nem testamento destinando os bens a terceiros" $" 54$.

Pode ocorrer, ainda, da sucessão ser mista, ou seja, quando a sucessão legítima e testamentária coexistirem. Nesta hipótese, em razão do instituto da reserva hereditária, quando houver herdeiros necessários, as disposições testamentárias não poderão ultrapassar metade dos bens do de cujus, ou seja, devem respeitar a quota legítima (artigo 1.789 do Código Civil).

Assim, havendo herdeiros necessários, o de cujus só poderá dispor livremente sobre a metade de seus bens que compõem a quota disponível. Por outro lado, se não houver herdeiros necessários, o testador poderá dispor livremente da totalidade de seus bens. Nesse caso, a liberdade de testar é plena.

Sobre o tema, Ana Luiza Maia Nevares explica:

\begin{abstract}
"Dessa maneira, pode-se dizer que a sucessão legítima se divide em sucessão legítima necessária e sucessão legitima não necessária. A sucessão legítima necessária é aquela que não pode ser excluída pela vontade do de cujus, dando origem aos herdeiros necessários e à quota necessária, também denominada legítima. Em contraposição a esta, há a quota disponível, ou seja, aquela parte do patrimônio que o de cujus pode livremente dispor por testamento., ${ }^{, 55}$
\end{abstract}

Nessa perspectiva, a parte legítima da herança é intangível, não pode ser retocada ou diminuída, pois pertence de pleno direito aos herdeiros necessários. Por isso, quando o de cujus tiver descendentes, ascendentes ou

\footnotetext{
${ }^{53}$ TEPEDINO, Gustavo et al.. Código Civil Interpretado: Conforme a Constituição da República, vol. IV. $1^{\text {a }}$ ed. Rio de Janeiro: Renovar, 2014. p.533.

${ }^{54}$ DIAS, Maria Berenice. Manual das Sucessões. $3^{\text {a }}$ ed. São Paulo: Editora dos Tribunais, 2013. p.137 .

${ }^{55}$ NEVARES, Ana Luiza Maia. A sucessão do cônjuge e do companheiro na perspectiva do direito civil-constitucional. $2^{\mathrm{a}}$ ed. São Paulo: Atlas, 2015. p.20.
} 
cônjuge, caso as disposições testamentárias ultrapassem mais da metade dos bens inventariados, elas serão reduzidas até o limite da quota legítima, ficando sem eficácia a parte excedente (artigo 1.967 do Código Civil).

Como se vê, o instituto da reserva hereditária, ou princípio da intangibilidade da legítima, concilia o princípio da liberdade de testar e da autonomia da vontade com princípios de solidariedade e proteção à família, na medida em que a livre disposição testamentária limita-se a metade dos bens inventariados.

Tendo em vista que este trabalho tem por objetivo verificar o regime de bens mais benéfico para o cônjuge e para o companheiro na perspectiva do Código Civil de 2002, só nos interessa estudar a sucessão prevista por lei, de modo que a sucessão testamentária está excluída do objeto de estudo.

\subsection{ORDEM DA VOCAÇÃO SUCESSÓRIA}

Na sucessão legítima, o legislador criou, no artigo 1.829 do Código Civil, uma ordem de vocação hereditária, estabelecida com base na "vontade presumida" do de cujus, ou seja, sob o fundamento de que o desejo do autor da herança seria deixar seus bens nessa sequência para os parentes mais próximos.

A ordem de vocação hereditária é, na verdade, uma ordem preferencial e excludente. Os herdeiros são divididos em classes enumeradas em ordem de preferência, de modo que cada classe só será chamada a suceder quando não houver nenhum herdeiro da classe antecedente. Assim, existindo um herdeiro na primeira classe enumerada no artigo, as outras classes ficam excluídas da sucessão.

Sobre o assunto, Luiz Paulo Vieira de Carvalho explica:

"Tal coordenação preferencial obedece o princípio de que os membros da classe ais próxima excluem os membros da classe mais remota, observando-se, entretanto, que, do mesmo modo, dentro da mesma classe, os membros de grau (geração) mais próximo ao falecido excluem 
os mais remotos, salvo se houver direito de representação (arts. 1.851 a 1.856 do CC), independentemente da concorrência de classes hoje admitida, porém dependente de determinadas condições legais". 56

Assim, a ordem de vocação hereditária inicia a sucessão com os descendentes, na ausência destes, passa aos ascendentes, em seguida ao cônjuge e depois herdam os parentes colaterais até $4^{\circ}$ grau. Por fim, inexistindo quaisquer herdeiros nessas classes, seguindo a ordem de preferência excludente, o Município, Distrito Federal ou União Federal herdarão os bens deixados.

A ordem de preferência também se dá dentro das classes. Ou seja, há preferência dos descendentes de grau mais próximo em detrimento dos mais distantes. Nesse contexto, todos os descendentes do mesmo grau de parentesco recebem partes iguais da legítima, afastando os demais descendentes de grau mais remotos, tais como netos e bisnetos. Esclareçase, ainda, que na sucessão dos descendentes não existe limite de grau.

A única exceção para esta regra é o direito de representação, que só existe no direito a herança dos descendentes e, excepcionalmente, na linha colateral (artigo 1.840 do Código Civil). A sucessão por representação ocorre quando o de cujus possui mais de um herdeiro e um deles é prémorto ou excluído por indignidade ou deserdação. Se este herdeiro possuir descendentes, a sucessão ocorrerá por cabeça para os descendentes de $1^{\circ}$ grau e por representação para os descendentes do herdeiro pré-morto ou excluído.

Não existindo descendentes, a sucessão passa para a classe dos ascendentes que também devem obedecer à ordem de preferência dentro da classe, bem como para sua sucessão não há limites de graus. A diferença é que não existe o direito de representação na sucessão de ascendentes. Por isso, se o pai ou a mãe do de cujus já tiverem falecido, o ascendente sobrevivente herda a totalidade da herança, de modo que os ascendentes do

\footnotetext{
${ }^{56}$ CARVALHO, Luiz Paulo Vieira de. Direito Civil: questões fundamentais e controvérsias na parte geral, no direito de família e no direito das sucessões. $4^{\circ}$ ed. Rio de Janeiro: Impetus, 2010. p. 276-277.
} 
outro lado, de graus de parentesco mais distantes (os avós), não herdam nada. Porém, estando ambos os pais mortos, e existindo avós dos dois lados, a herança será divida de modo que cada lado, paterno e materno, fique com a metade dos bens. Ainda que um dos avós, de um lado, tenha falecido, a herança é divida pela metade. Assim, se, por exemplo, o avô paterno falece, a avó paterna fica com metade da herança e os avós maternos ficam com a outra metade, de modo que cada um tem direito à $1 / 4$ da herança.

Conforme analisaremos com mais detalhes no próximo capítulo, o artigo 1.829 do Código Civil prevê uma peculiaridade na sucessão dos descendentes e dos ascendentes, qual seja a concorrência do cônjuge

sobrevivente com essas duas classes, salvo quando este for casado com o falecido pelo regime de comunhão universal, ou separação obrigatória, ou, ainda, se na comunhão parcial o de cujus não tiver deixados bens particulares.

Além disso, não havendo descendentes, ascendentes ou disposições testamentárias, o cônjuge sobrevivente herda sozinho a universalidade dos bens.

Por fim, existe relevante polêmica acercada sucessão do companheiro, não só por ele não ter sido incluído na redação do artigo que estabelece a ordem de vocação hereditária, mas também por aparentemente não estar entre os herdeiros que a lei qualifica como necessários.

\subsection{O DIREITO DE CONCORRÊNCIA}

O direito de concorrência possui natureza jurídica de direito hereditário. Através desse direito, a lei assegura ao cônjuge e ao companheiro o direito de participar da herança ao lado dos descendentes e ascendentes.

Nesse contexto, a concorrência quebra o princípio da preferenciabilidade dos herdeiros mais próximos, pois os cônjuges, 
herdeiros da $3^{\mathrm{a}}$ classe na ordem de preferência, serão chamados a suceder junto com os descendentes e ascendentes, que compõe a $1^{\mathrm{a}}$ e $2^{\mathrm{a}}$ classe, respectivamente. Assim, a herança será destinada a herdeiros de classes diferentes, excepcionando a ordem preferencial e excludente.

Vale destacar, neste ponto, que, apesar do cônjuge e do companheiro serem beneficiários do direito de concorrência, as parcelas da herança são diferenciadas, obedecendo critérios distintos, conforme veremos a seguir.

Nas palavras de Maria Berenice, "o direito de concorrência é imposto por lei, transformando cônjuge e companheiro em herdeiros necessários a porção da herança que recebem a este título"57. Portanto, o cônjuge e o companheiro só serão privados da quota referente ao direito de concorrência se forem excluídos por deserdação ou indignidade.

Outro ponto importante é que, assim como ocorre na sucessão legítima, o testador também pode impor limitações à quota herdada em concorrência pelo cônjuge e companheiro, tais como cláusula de impenhorabilidade, inalienabilidade ou incomunicabilidade, desde que justificado.

Além disso, conforme observaremos a seguir, para calcular as quotas da herança é preciso saber o estado civil do autor da herança, bem como sob qual regime de bens se deu a relação, a fim de verificar se há necessidade de reservar quotas referentes ao direito à meação e de concorrência.

Com efeito, o direito à meação distingui-se do direito de concorrência, na medida em que neste ocorre transferência dos bens à título de herança, enquanto que naquele a parcela do patrimônio que cabe ao cônjuge ou companheiro sobrevivente já era de sua titularidade. Em outras palavras, não há que se falar em transmissão no direito à meação, já que o cônjuge ou companheiro sobrevivente sempre possuiu a titularidade sobre metade dos bens do casal, mesmo antes da morte. Assim, com o falecimento de um dos consortes, o patrimônio amealhado deve ser dividido, de modo que metade

\footnotetext{
${ }^{57}$ DIAS, Maria Berenice. Manual das Sucessões. $3^{\text {a }}$ ed. São Paulo: Editora dos Tribunais, 2013. p.151.
} 
integra o patrimônio do sobrevivente e a outra metade pertencerá ao espólio, e comporá o monte a ser partilhado.

\subsection{A EVOLUÇÃO HISTÓRICA DO DIREITO SUCESSÓRIO DO CÔNJUGE E DO COMPANHEIRO}

Desde as Ordenações Filipinas até o advento da "Lei Feliciano Pena" (Lei $\left.n^{\circ} 1.939 / 1907\right)$, o cônjuge ocupava o quarto lugar na ordem de vocação hereditária, sendo chamado a sucessão apenas depois dos colaterais até o décimo grau. Com a "Lei Feliciano Pena", mantida no Código Civil de 1917, o cônjuge passou a ocupar o terceiro lugar da ordem, herdando após os descendentes e ascendentes.

Apesar de ter preservado a inovação da ordem de vocação hereditária, o Código Civil de 1917 manteve o cônjuge como herdeiro legítimo não necessário, ou seja, o cônjuge poderia ser excluído da sucessão por disposições testamentárias que não o contemplassem.

Com o advento do "Estatuto da Mulher Casada" (Lei n 4.121/62), o Código Civil de 1916 foi alterado, no sentido de instituir para o cônjuge sobrevivente o usufruto vidual. Nos termos do novo parágrafo introduzido pela lei, o cônjuge sobrevivente teria direito à quarta parte dos bens do falecido, quando houvesse filhos deste ou do casal; ou, não havendo filhos, à metade do patrimônio quando o regime do matrimônio não fosse o da comunhão total. Dessa forma, o cônjuge teria que repartir com os ascendentes a metade do patrimônio do de cujus.

Outra novidade trazida pelo "Estatuto da Mulher Casada", que permanece até hoje em nosso ordenamento jurídico, é o direito real de habitação relativamente ao imóvel destinado à residência da família, desde

que seja o único bem daquela natureza a inventariar, vigorando enquanto o cônjuge supérstite permanecer vivo. Àquela época, só fazia jus a este direito o cônjuge casado pelo regime da comunhão universal, diferentemente de hoje em que este direito independe do regime de bens. 
Em 1977, com o advento da Lei $\mathrm{n}^{\mathrm{o}}$ 6.515, o regime supletivo do casamento deixou de ser o da comunhão universal e passou a ser o da comunhão parcial, o que gerou efeitos na sucessão do cônjuge. Isso porque, "este, em diversas hipóteses, poderia se ver totalmente desamparado em virtude da morte de seu consorte, quando, por exemplo, não havia bens [comuns]a partilhar" ${ }^{\prime \prime 58}$.

Por fim, o atual Código Civil prestigiou o cônjuge ao elevá-lo a categoria de herdeiro necessário, o que lhe garantiu o direito à legítima, bem como o direito de concorrência e o direito real de habitação, independentemente do regime de bens.

A evolução do direito sucessório do companheiro, por sua vez, foi ainda mais lenta e penosa. Tendo em vista que, à época do Código Civil de 1916, a única forma de constituição de família aceita era por meio do casamento, o companheiro não era contemplado como herdeiro. $\mathrm{Na}$ verdade, o Código Civil de 1916 só possuía previsões de efeitos negativos para companheiro, tais como a proibição de instituir seguro de vida em benefício dele.

Pouco a pouco, o cenário foi sendo alterado, de modo que algumas leis e posicionamentos de tribunais começaram a conferir alguns direito aos companheiros. No entanto, a união estável só foi reconhecida como entidade familiar com a Constituição Federal de 1988, em seu artigo 226, $\S 3^{\circ}$. A partir daí, alguns avanços foram realizados em relação ao companheiro, principalmente porque o concubinato deixou de ser regulado pelo Direito das Obrigações e passou para o campo do Direito de Família.

Com o reconhecimento da união estável como entidade familiar, o fato da legislação infraconstitucional sucessória não contemplar o companheiro como herdeiro passou a ser um problema. Para solucionar essa questão, passou-se a aplicar, por analogia, os direitos sucessórios conferidos ao cônjuge à união estável.

\footnotetext{
${ }^{58}$ NEVARES, Ana Luiza Maia. A sucessão do cônjuge e do companheiro na perspectiva do direito civil-constitucional. $2^{\mathrm{a}}$ ed. São Paulo: Atlas, 2015. 3 p.
} 
Por fim, com as Leis $\mathrm{n}^{\mathrm{os}} 8.971 / 94$ e 9.278/96 - que previam, para o companheiro, respectivamente, o direito ao usufruto dos bens do falecido, nos moldes do direito de usufruto que era conferido ao cônjuge; e o direito real de habitação relativamente ao imóvel que era destinado à residência da família enquanto viver ou não constituir nova união ou casamento — os direitos sucessórios do companheiro avançaram ainda mais.

Antes da Lei no 8.971/94, a sucessão dos concubinos era regulada pela súmula $\mathrm{n}^{\mathrm{o}} 380$ do Supremo Tribunal Federal ${ }^{59}$, segundo a qual, comprovada a sociedade de fato, o patrimônio adquirido por esforço comum seria dividido entre os consortes.

Hoje, com o Código Civil de 2002, o companheiro participa da sucessão dos bens adquiridos onerosamente na constância da união estável, bem como possui direito de concorrência com os descendentes e outros parentes suscetíveis do de cujus.

Cabe ressaltar, neste ponto, que o artigo que trata da sucessão do companheiro no Código Civil atual foi fruto de uma emenda, inserida no Projeto, quando este já estava pronto. Assim, como o Projeto de Código Civil aprovado com emendas em 1984 não previa nenhum dispositivo que regulasse a sucessão do companheiro, durante sua tramitação no Senado Federal, o senador Nélson Carneiro apresentou uma proposta de emenda ao Projeto com o objetivo de suprimir essa lacuna, criando o artigo 1.790 do atual Código Civil.

No entanto, apesar de instituir para o companheiro direitos sucessórios, representando um avanço em relação ao sistema anterior, esse artigo foi muito criticado, não só por estar localizado entre as disposições gerais do Direito Sucessório, quando, na verdade, estaria melhor regulado no Título pertinente à Sucessão Legítima, mas também por ser deficiente e falho em substância.

\footnotetext{
${ }^{59}$ Súmula $\mathrm{n}^{\mathrm{o}} 380$ do STF: Comprovada a existência de sociedade de fato entre os concubinos, é cabível a sua dissolução judicial, com a partilha do patrimônio adquirido pelo esforço comum.
} 
Assim, ainda que a sucessão do companheiro tenha evoluído bastante a partir da Constituição Federal de 1988, muitos autores ainda criticam a diferença no tratamento destinado ao cônjuge e ao companheiro, como se houvesse hierarquia entre as entidades familiares. 


\subsection{REQUISITOS DE LEGITIMIDADE PARA SUCEDER}

Antes de analisar o quinhão da herança que cabe ao cônjuge sobrevivente, é preciso verificar sua legitimidade para participar da sucessão dos bens deixados pelo de cujus.

Para tanto, é preciso fazer um leitura cuidadosa do artigo 1.830 do Código Civil, segundo o qual o cônjuge sobrevivente só terá legitimidade para suceder, se, ao tempo da morte do outro, não estava separado judicialmente do autor da herança, nem separado de fato há mais de dois anos, salvo prova, neste caso, de que a interrupção na convivência não se deu por sua culpa.

Como se vê, a dissolução da sociedade conjugal, tanto pela separação judicial, quanto pelo divórcio, extingue, dentre outros direitos, o direito sucessório do cônjuge sobrevivente à herança de seu exconsorte.

No entanto, na hipótese de um dos cônjuges falecer durante o processo de separação judicial ou divórcio, se a morte ocorrer antes do trânsito em julgado da sentença que o decreta, o processo será extinto, de modo que o cônjuge sobrevivente permanecerá com o status de casado. Assim, tendo em vista que os efeitos da separação judicial ou do divórcio só serão produzidos após o trânsito em julgado da sentença, seu direito à herança do cônjuge falecido restará resguardado.

Sobre o tema, Gustavo Tepedino, Maria Celina Bodin de Moraes e Heloisa Barboza explicam:

\footnotetext{
"Se já decretada a separação judicial ou o divórcio, um dos cônjuges falece, o sobrevivente está excluído da sucessão. Mas se a morte ocorre pendente a ação dissolutória, o respectivo processo será extinto, e o casamento mantido e resguardado o direito sucessório do cônjuge. No caso de falecimento se verificar quando pendente recurso da sentença de
} 
separação ou divórcio, os tribunais entendem que o cônjuge ainda não separado era viúvo, e teria direito à sucessão." ${ }^{60}$

Nesse sentido, a jurisprudência do Tribunal de Justiça do Estado do Rio de Janeiro:

“Apelação Cível. Ação de separação litigiosa. Falecimento da autora no curso da demanda. extinção do feito sem análise do mérito, na forma do artigo 267, inciso VI, do Código de Processo Civil. Recurso do réu pugnando pelo acolhimento do pedido formulado na reconvenção, consistente na declaração do divórcio. impossibilidade. Óbito da autora que põe termo à demanda. Pretensão deduzida que ostenta caráter intransmissível. Orientação do c. STJ e deste e. TJRJ. Recurso conhecido e desprovido. artigo 557, caput, do CPC. correção da sentença que se faz, de ofício, para que o feito seja extinto sem o julgamento do mérito, na forma do artigo 267, inciso IX do CPC."

E, ainda, o julgado do Superior Tribunal de Justiça:

"Ação de divórcio direto. Legitimidade do Espólio. Habilitação.

Ausência de impugnação. Coisa julgada. Falecimento do varão antes do julgamento dos recursos contra o despacho que não admitiu os especiais. Precedente da Corte.

1. Tendo o Espólio requerido a sua habilitação oportunamente, sem a devida impugnação da parte interessada, não pode mais o tema ser renovado no âmbito do especial.

2. Falecendo o varão antes de transitada em julgado a decisão que concedeu o divórcio, embora em execução provisória, porque pendente o julgamento de recursos contra os despachos que não admitiram os especiais, o estado civil do cônjuge sobrevivente é de viúva, não de divorciada.

3. Recurso especial conhecido e provido." ${ }^{62}$

Por outro lado, quando a separação judicial ou o divórcio forem consensuais e um dos cônjuges falecer no curso do processo, o outro não terá legitimidade para suceder, eis que a sentença homologatória do acordo retroage a data em que foi firmado.

No que concerne à legitimidade do cônjuge sobrevivente separado de fato, o legislador impõe dois requisitos para sua exclusão: a convivência

\footnotetext{
${ }^{60}$ TEPEDINO, Gustavo et al.. Código Civil Interpretado: Conforme a Constituição da República, vol. IV. $1^{a}$ ed. Rio de Janeiro: Renovar, 2014. p. 636-637.

${ }^{61}$ TJRJ. Apelação Cível no 0215978-16.2009.8.19.0001, Rel. Des. Maria Regina Nova Alves, Rio de Janeiro, 22 de abril de 2015.

${ }^{62}$ STJ. REsp. ${ }^{\circ}$ 239.195/SP, Rel. Min. Carlos Alberto Menezes Direito, Brasília, 20 de setembro de 2001
} 
deve ter cessado há mais de dois anos (temporal); e a separação deve ter ocorrido por sua culpa (subjetivo).

Em relação àquele requisito, se por um lado Mario Roberto Carvalho de Faria afirma que cabe aos herdeiros, em ação própria, comprovar que a separação de fato se deu por período superior há dois anos; por outro, José Luiz Gavião de Almeida afirma que esta prova cabe ao cônjuge sobrevivente $^{63}$. Independentemente de quem deva produzi-la, a ilegitimidade deve ser arguida em ação própria, já que os autos do inventário destinam-se apenas ao arrolamento dos bens do falecido e sua partilha entre os herdeiros, não sendo, portanto, a via adequada para outras discussões.

Assim, sendo o lapso temporal igual ou inferior a dois anos, o cônjuge terá legitimidade para suceder. E, mesmo que o casal esteja separado por mais de dois anos, cabe aos herdeiros também a prova de que a separação se deu por culpa do cônjuge sobrevivente.

Sobre o tema Mario Roberto Carvalho de Faria explica:

\begin{abstract}
"Todos esses fatos deverão ser apreciados em ação própria, competindo aos herdeiros fazer a prova para excluir o cônjuge da sucessão. A nosso sentir, não cabe ao cônjuge fazer qualquer prova, exceto a de que é casado. Todas as vezes que o legislador permitiu a exclusão de herdeiros (indignidade e deserdação) impôs aos interessados na herança a obrigação de propor a ação competente para exclusão, portanto, competirá aos parentes interessados na sucessão propor a ação." ${ }^{\circ 4}$
\end{abstract}

Note-se, ainda, que, quanto ao requisito da culpa na separação de fato, esta não deve ser confundida com a vontade de separar. Por óbvio, o cônjuge que sofre ofensas físicas ou verbais não terá mais o desejo de conviver com o outro. Nesse caso, por exemplo, apesar de partir de um cônjuge a vontade e a decisão de se separar, a culpa deve ser imputada ao outro, que não agiu com respeito aos deveres conjugais.

\footnotetext{
${ }^{63}$ ALMEIDA, José Luiz Gavião de. Código Civil Comentado, XXIII. p.216 apud TEPEDINO, Gustavo et al.. Código Civil Interpretado: Conforme a Constituição da República, vol. IV. $1^{\mathrm{a}}$ ed. Rio de Janeiro: Renovar, 2014. p. 637.

${ }^{64}$ FARIA, Mario Roberto Carvalho de. Direito das Sucessões: teoria e prática. $7^{\text {a }}$ ed. Rio de Janeiro: Forense, 2013. p.118.
} 
A doutrina critica severamente os requisitos previstos pelo legislador. No que tange ao requisito temporal, Paulo Lôbo chama a atenção para o fato de que, ao ser interpretada isoladamente, a regra vai de encontro com a previsão de que o cônjuge casado, mas separado de fato, pode, a qualquer tempo, constituir união estável com outra pessoa (artigo 1.723, caput e $\S 1^{\circ}$, do Código Civil). ${ }^{65}$

Como bem observa Ana Luiza Maia Nevares, pela interpretação literal da lei, nos casos em que um cônjuge separado de fato constituir união estável, se essa separação ocorreu há menos de dois anos ou por culpa do outro, pode-se concluir que ambos, cônjuge e companheiro, possuem legitimidade para suceder.

Nessa hipótese, a doutrina diverge quanto aos legitimados para suceder: de um lado, Ana Luiza Nevares entende que a duplicidade de sucessão é apenas aparente e que, portanto, o companheiro seria o único legitimado, já que evidente a quebra do affectio maritalis (artigo 1.511 do Código Civil) ${ }^{66}$; de outro, Gustavo Tepedino, Heloisa Barboza e Maria Celina Bodin de Moraes acreditam que, quando a separação de fato se dá por culpa do cônjuge que constituiu a união estável, ambos, companheiro e cônjuge, herdam em concorrência, seguindo a lógica do artigo 1.790 do código Civil. Em suas palavras,

"se não é justo penalizar o cônjuge que não deu causa ao rompimento da vida conjugal, igualmente não se pode excluir o companheiro que constituiu nova família e conviveu com o autor da herança até sua morte". ${ }^{67}$

Por sua vez, no que concerne ao requisito de culpa, a doutrina entende não ser cabível condicionar a exclusão do cônjuge separado de fato à comprovação da ausência de culpa. Nesse sentido, Ana Luiza Maia Nevares critica:

\footnotetext{
${ }^{65}$ LÔBO, Paulo. Direito Civil: Sucessões. $1^{\text {a }}$ ed. São Paulo: Saraiva, 2013. p.123.

${ }^{66}$ NEVARES, Ana Luiza Maia. A sucessão do cônjuge e do companheiro na perspectiva do direito civil-constitucional. $2^{\mathrm{a}}$ ed. São Paulo: Atlas, 2015. p.92 .

${ }^{67}$ TEPEDINO, Gustavo et al.. Código Civil Interpretado: Conforme a Constituição da República, vol. IV. $1^{\mathrm{a}}$ ed. Rio de Janeiro: Renovar, 2014. p.638.
} 
"Com efeito, a partir da concepção do afeto entre os cônjuges como fundamento do casamento, que se apóia na plena comunhão de vida (CC/02, art. 1.511), abandona-se cada vez mais a noção de culpa na dissolução da sociedade conjugal. [...] Com a dissolubilidade do casamento, a igualdade entre os cônjuges e a compreensão da família como organismo social destinado a promover o desenvolvimento da personalidade de seus membros, sendo um instrumento destinado a promover o desenvolvimento da personalidade de seus membros, sendo um instrumento de proteção da pessoa, não mais se justifica a perquirição da culpa na dissolução da sociedade conjugal.",68

Deve-se, portanto, analisar cuidadosamente os requisitos do artigo 1.830 do Código Civil para avaliar se o cônjuge sobrevivente separado judicialmente, divorciado ou separado de fato tem direito a um quinhão da herança.

\subsection{O CÔNJUGE EM CONCORRÊNCIA COM OS DESCENDENTES}

Segundo a lógica do artigo 1.829, inciso I, do Código Civil, o direito de concorrência do cônjuge guarda relação com o regime de bens escolhido pelo casal.

Nessa perspectiva, o cônjuge não concorrerá com os descendentes e, portanto, não participará da sucessão de seu consorte, quando casado pelo regime de comunhão universal de bens, separação obrigatória ou da comunhão parcial, na hipótese em que o falecido não tiver deixado bens particulares. Por conseguinte, terá direito à sucessão do de cujus, em concorrência com seus descendentes, o cônjuge casado pelo regime de separação convencional, participação final nos aquestos ou comunhão parcial, se existirem bens particulares.

Conforme analisa Ana Luiza Maia Nevares, "verifica-se, portanto, que o cônjuge é afastado da sucessão quando em virtude do regime de bens já tem proteção patrimonial por força da meação",69, ou quando a lei impõe

\footnotetext{
${ }^{68}$ NEVARES, Ana Luiza Maia. Op. cit., p. 91.

${ }^{69}$ Ibid, p. 94.
} 
o regime de separação obrigatória, a fim de sancioná-lo, por não observar as causas suspensivas na celebração do casamento, ou para protegê-lo.

Note-se, ainda, que com a dissolução da sociedade conjugal, em decorrência do falecimento do cônjuge casado pelo regime da separação obrigatória, o cônjuge sobrevivente terá direito à meação nos termos da súmula $\mathrm{n}^{\mathrm{o}} 377$ do Supremo Tribunal Federal. Nesse sentido, Luciano Vianna Araújo afirma que seria desnecessário atribui a ele o direito de concorrência com os descendentes:

\begin{abstract}
"Na forma da Súmula no 377 do Supremo Tribunal Federal, "no regime de separação legal de bens, comunicam-se os adquiridos na constância do casamento". A prevalecer esse entendimento, na nova ordem civil, ao cônjuge sobrevivente competirá metade dos bens adquiridos na constância do matrimônio. Logo, desnecessário seria atribuir-lhe, em concorrência com os descendentes, mais alguma cota da herança."
\end{abstract}

\title{
3.2.1 Controvérsias sobre o direito à concorrência
}

Como se vê, a redação do artigo 1.829, inciso I, do Código Civil não é clara e sua interpretação tem gerado polêmica doutrinária e jurisprudencial.

No que tange à concorrência entre os descendentes e o cônjuge sobrevivente casado pelo regime da comunhão parcial, o dispositivo estabelece que este só herdará quando o de cujus tiver deixado bens particulares, já que, em relação aos bens comuns, ele possui direito à meação. Assim, se os únicos bens do de cujus forem os comuns, o cônjuge sobrevivente, embora casado pelo regime de comunhão parcial, estará em situação idêntica àquele que casou pelo regime de comunhão universal, de modo que só fará jus ao direito à meação, nos termos do inciso I, do artigo 1.829, do Código Civil.

A partir dessa redação, surgiu controvérsia quanto à massa de bens sobre a qual recai o direito à concorrência, se incidiria: (i) sobre todo o

\footnotetext{
${ }^{70}$ ARAÚJO, Luciano Vianna. Ordem de vocação hereditária no novo Código Civil: os direitos sucessórios do cônjuge. in ADV - Advocacia Dinâmica, Rio de Janeiro, 2002.
} 
monte, ou seja, todos os bens deixados pelo de cujus; (ii) apenas sobre aqueles adquiridos onerosamente na constância do casamento, excluída a meação do cônjuge sobrevivente; ou (iii) tão somente sobre os bens particulares, aqueles adquiridos antes do casamento. ${ }^{71}$

A primeira interpretação, defendida por Maria Helena Diniz, Paulo Nader e outros, decorre do fato de que o inciso I, do artigo 1.829, do Código Civil afirmou que o direito à concorrência recaia sobre a herança e esta, como se sabe, compreende todos os bens do falecido. Desse modo, além do direito à meação, o cônjuge sobrevivente também teria direito à herdar, em concorrência com os descendentes, todos os bens do acervo.

Nesse sentido, Mario Roberto Faria explica:

"Não tendo o legislador especificado se o direito à herança incide somente sobre os bens particulares, entendemos que o cônjuge herdará tanto os bens particulares quanto os aquestos". ${ }^{72}$

Essa corrente fortalece o conceito de "monte hereditário", ou seja, que a herança é uma universalidade de direito que é transmitida para os herdeiros como um todo unitário. Admitir que o cônjuge sobrevivente concorra com os descendentes apenas em parte dela enfraqueceria este conceito.

No REsp. no 974.241/DF, julgado em 05/10/2011, o Ministro Luís Felipe Salomão mostrou-se adepto dessa primeira corrente, ao determinar, em seu voto vista, que o direito à concorrência deve incidir sobre todo o acervo hereditário $^{73}$.

Cabe ponderar, neste ponto, que, em uma análise apressada, concluir-se-ia que o cônjuge estaria em uma posição de vantagem em relação aos descendentes, já que, além da meação, o direito à concorrência do cônjuge sobrevivente ainda incidiria sobre todo o monte. Porém, se considerarmos que o direito à meação é direito próprio, e não sucessório,

\footnotetext{
${ }^{71}$ STJ, REsp. no 1.368.123-SP, Rel. Min. Sidnei Beneti, Brasília, 22 de abril de 2015.

${ }^{72}$ FARIA, Mario Roberto Carvalho de. Direito das Sucessões: teoria e prática. $7^{\mathrm{a}}$ ed. Rio de Janeiro: Forense, 2013. p.96 .

${ }^{73}$ STJ. REsp. no 974.241-DF, Rel. Min. Luis Felipe Salomão, Brasília, 05 de outubro de 2015.
} 
não faria sentido considerar a meação nesta análise. Ainda assim, conforme explicado abaixo, no item 3.2.2, se o de cujus possui mais de três filhos, os descendentes estariam em desvantagem, já que o artigo 1.832 do Código Civil estabelece que a quota do cônjuge sobrevivente, em concorrência com os descendentes, não pode ser inferior à quarta parte da herança.

A segunda corrente visa excluir os bens particulares do direito de concorrência, já que estes também não se comunicavam quando o autor da herança estava vivo. Desse modo, o cônjuge sobrevivente, além do direito à meação, herdaria sobre os bens adquiridos onerosamente na constância do casamento.

Esse foi o entendimento da Ministra Nancy Andrighi no julgamento do REsp. no 1.117.563-SP, julgado em 06/04/2010, e da terceira turma do Superior Tribunal de Justiça no julgamento do REsp. $\mathrm{n}^{\circ}$ 1.377.084-MG, em 15/10/2013, também relatado pela Ministra ${ }^{74,75}$.

Em seu voto, a Ministra Nancy Andrighi enfatizou a importância da vontade das partes na escolha do regime de bens para o direito sucessório:

"Por tudo isso, a melhor interpretação é aquela que prima pela valorização da vontade das partes na escolha do regime de bens, mantendo-a intacta, assim na vida como na morte dos cônjuges. Desse modo, preserva-se o regime da comunhão parcial de bens de acordo com o postulado da autodeterminação, ao contemplar o cônjuge sobrevivente com o direito a meação, além da concorrência hereditária sobre os bens comuns, haja ou não bens particulares, partilháveis, estes, unicamente entre os descendentes". ${ }^{76}$

Esta corrente fundamenta-se no princípio da autonomia da vontade, bem como na equiparação da sucessão do cônjuge casado pelo regime de comunhão parcial com a do companheiro, através de uma aplicação analógica do artigo 1.790 do Código Civil. O Ministro Sidnei Beneti, em seu voto no REsp. n ${ }^{o} 1.368 .123$, de sua relatoria, julgado em 22/04/2015, critica essa equiparação:

\footnotetext{
${ }^{74}$ STJ. REsp. no 1.117.563-SP, Rel. Min. Nancy Andrighi, Brasília, 06 de abril de 2010.

${ }^{75}$ STJ. REsp. no 1.377.084-MG, Rel. Min. Nancy Andrighi, Brasília, 15 de outubro de 2013.

${ }^{76}$ STJ. REsp. n ${ }^{\mathrm{o}}$ 1.117.563-SP, Rel. Min. Nancy Andrighi, Brasília, 06 de abril de 2010.
} 
"É preciso reconhecer, no entanto, que existem limites à atividade exegética. No caso específico da sucessão do cônjuge, por exemplo, é preciso reconhecer que o Código trouxe regras próprias para a sucessão do companheiro e para a sucessão do cônjuge". ${ }^{77}$

Seguindo a mesma lógica, Maria Berenice, em seu artigo "Ponto-evírgula”, defende que o cônjuge sobrevivente casado pelo regime de comunhão parcial, além de fazer jus à meação, teria direito a concorrer com os descendentes na sucessão dos bens comuns, sendo, contudo, excluído da sucessão dos bens particulares:

\begin{abstract}
"Quando o regime é o da comunhão parcial e não existem bens particulares, significa que todo o acervo hereditário foi adquirido depois do casamento, ocorrendo a presunção da mutua colaboração, o que torna razoável que o cônjuge, além da meação, concorra com os filhos na herança. No entanto, quando há bens amealhados antes do casamento, nada justifica que participe o cônjuge desse acervo. Tal não se coaduna com a natureza do regime da comunhão parcial, sendo descabido que venha o cônjuge sobrevivente a herdar parte do patrimônio individual, quando da morte do par.",78
\end{abstract}

A terceira corrente, defendida por Hironaka, entende que o cônjuge sobrevivente só teria direito a concorrer com os descendentes na sucessão dos bens particulares ${ }^{79}$. Isto porque, o direito à meação seria suficiente para resguardar a situação patrimonial do cônjuge sobrevivente.

No mesmo sentido, o Enunciado $\mathrm{n}^{\circ} 270$, aprovado pelo III Jornada de Direito Civil dispõe:

\begin{abstract}
“Art. 1.829: O art. 1.829, inc. I, só assegura ao cônjuge sobrevivente o direito de concorrência com os descendentes do autor da herança quando casados no regime da separação convencional de bens ou, se casados nos regimes da comunhão parcial ou participação final nos aquestos, o falecido possuísse bens particulares, hipóteses em que a concorrência se restringe a tais bens, devendo os bens comuns (meação) ser partilhados exclusivamente entre os descendentes."
\end{abstract}

\footnotetext{
${ }^{77}$ STJ. REsp. no 1.368.123. Rel. Min. Sidnei Beneti, Brasília, 22 de abril de 2015.

${ }^{78}$ DIAS, Maria Berenice. Ponto-e-vírgula. Disponível em:http://mariaberenice.com.br/uploads/1 _ponto_e v\%EDrgula.pdf. Acessado em 15.09.2015

${ }^{79}$ HIRONAKA, Gisela Maria Fernandes Novaes. Comentários ao Código Civil: parte especial do direito das sucessões, vol. 20. São Paulo: Saraiva, 2003. p. 220 apud TEPEDINO, Gustavo et al.. Código Civil Interpretado: Conforme a Constituição da República, vol. IV. $1^{\mathrm{a}}$ ed. Rio de Janeiro: Renovar, 2014. p. 630 .

${ }^{80}$ Enunciados aprovados na III Jornada de Direito Civil. Disponível em: http://daleth.cjf.jus.br/revista/enunciados/IIIJornada.pdf . Acessado em 15.09.2015.
} 
Recentemente, a Segunda Seção do Superior Tribunal de Justiça uniformizou seu entendimento, ao julgar o REsp. $\mathrm{n}^{\mathrm{o}}$ 1.368.123-SP, no sentido de que o cônjuge sobrevivente, casado sob o regime da comunhão parcial de bens, concorre com os descendentes na sucessão do falecido apenas quanto aos bens particulares que este houver deixado, se existirem ${ }^{81}$.

Em uma análise crítica das diversas correntes apresentadas, me parece mais acertada a segunda corrente, segunda a qual o direito de concorrência incidiria apenas sobre os bens comuns. Isto porque, ao firmar o pacto antenupcial, o cônjuge falecido manifestou sua vontade no sentido de só comunicarem os bens comuns, de modo que a vontade do de cujus manifestada em vida também deve ser respeitada após a sua morte.

Outra polêmica decorrente da redação do artigo 1.829, I, do Código Civil, diz respeito ao cônjuge casado pelo regime da separação convencional.

Apesar do dispositivo determinar expressamente que o cônjuge casado pelo regime da separação convencional de bens concorre com os descendentes na sucessão dos bens deixados pelo de cujus, existem julgados e doutrinadores que defendem a sua exclusão da sucessão.

Para os que possuem esse entendimento, tais como Miguel Reale e Judith Martins Costa, reconhecer o direito à concorrência do cônjuge casado pelo regime de separação convencional seria desconsiderar a vontade do de cujus, o que me parece mais correto.

Em outras palavras, esta corrente está fundamentada no princípio da autonomia da vontade, de modo que a vontade manifestada na escolha do pacto antenupcial deve se espelhar na sucessão hereditária.

Logo, se o de cujus optou por um regime em que não há comunicabilidade de patrimônios, não faria sentido que os patrimônios se comunicassem após a sua morte, desrespeitando sua vontade manifestada em vida. Por isso, deveria haver uma projeção das consequências do regime

\footnotetext{
${ }^{81}$ STJ. REsp. $\mathrm{n}^{\mathrm{o}}$ 1.368.123. Rel. Min. Sidnei Beneti, Brasília, 22 de abril de 2015.
} 
de bens do casamento na atribuição de direitos sucessórios ao cônjuge, de modo a cumprir a vontade de cujus mesmo após a sua morte.

Além disso, conforme apontado por Miguel Reale e Judith Martins, ao permitir que o cônjuge sobrevivente casado pelo regime da separação convencional de bens concorra com os descendentes, gera-se uma contradição no sistema, pois, se por uma lado é reconhecido aos nubentes a possibilidade de escolher um regime que prevê a incomunicabilidade de patrimônios; por outro, essa possibilidade lhes seria negada por uma imposição de uma comunicabilidade após a morte. Assim, haveria uma antinomia entre os artigos 1.829 , I, e $1.687^{82}$ do Código Civil ${ }^{83}$.

Argumenta-se, ainda, que o cônjuge sobrevivente casado pelo regime de separação convencional, ao se habilitar no processo de inventário de seu consorte, estaria ferindo o princípio da boa-fé objetiva, já que estaria pleiteando direito do qual declinou no momento da escolha do pacto antenupcial.

Até pouco tempo, o Superior Tribunal de Justiça possuía entendimento reiterado no sentido de que o regime de separação obrigatória de bens é gênero que consagra duas espécies: a separação legal e a convencional. Uma decorre da lei e outra da vontade das partes e ambas obrigam os cônjuges. Assim, o cônjuge casado mediante separação de bens não teria direito à meação e tampouco à concorrência sucessória, respeitando-se o regime de bens estipulado, que obriga as partes na vida e na morte. Nos dois casos o cônjuge não seria herdeiro necessário. (STJ, REsp. n 992749/MS, Rel. Min. Nancy Andrighi, j. 01/12/2009; STJ, REsp. $\mathrm{n}^{\mathrm{o}}$ 1.111.095/RJ, Rel Min. Fernando Gonçalves, public. 11/02/2010; STJ REsp. $n^{\circ} 1117563 /$ SP Rel. Min. Nancy Andrighi, j. 06/04/2010).

\footnotetext{
82 “Art. 1.687. Estipulada a separação de bens, estes permanecerão sob a administração exclusiva de cada um dos cônjuges, que os poderá livremente alienar ou gravar de ônus real."

${ }^{83}$ MARTINS-COSTA Judith. REALE, Miguel. "Direito Civil. Sucessões. Casamento sob o regime de separação total de bens, voluntariamente escolhido pelos nubentes. apud NEVARES, Ana Luiza Maia. A sucessão do cônjuge e do companheiro na perspectiva do direito civilconstitucional. $2^{\mathrm{a}}$ ed. São Paulo: Atlas, 2015. p.97.
} 
No REsp. n 992749/MS, a Ministra Nancy Andrighi sintetizou bem este entendimento:

"O regime de separação obrigatória de bens, previsto no art. 1.829, inc. I, do $\mathrm{CC} / 02$, é gênero que consagra duas espécies: (i) separação legal; (ii) separação convencional. Uma decorrente da lei e outra da vontade das partes, e ambas obriga os cônjuges, uma vez estipulado o regime de separação de bens, à sua observância.

Não remanesce, para o cônjuge casado mediante separação de bens, direito à concorrência sucessória respeitando-se o regime de bens estipulado, que obriga as partes na vida e na morte. Nos dois casos, portanto, o cônjuge sobrevivente não é herdeiro necessário." ${ }^{84}$

Com efeito, a posição acima indicada está contida no Projeto de Lei $1.792 / 2007^{85}$, que tramita na Câmara dos Deputados, cujo o objetivo é excluir o cônjuge casado pelo regime de separação convencional do rol de herdeiros necessários, alterando, para tanto, a redação do artigo 1.829, I, do Código Civil.

No que tange à separação obrigatória, Luiz Paulo Vieira critica o disposto no artigo 1.829, I, do Código Civil:

“Em nosso entender, será visto adiante, a restrição em comento tão-só terá sentido, se aceitarmos a subsistência em nosso ordenamento da Súmula $\mathrm{n}^{\circ} 377$ do STF, sob pena de deixar ao desamparo, in concreto, o cônjuge supérstite do lar, aquele que não amealhou patrimônio, o que se figura como realidade, aliais, de um grande percentual de viúvas brasileira". ${ }^{86}$

Apesar de seu posicionamento reiterado, recentemente, o Superior Tribunal de Justiça passou a proferir decisões reiteradas no sentido de que o cônjuge concorre com descendentes do falecido sobre todos os bens, uma vez que a lei afasta apenas a concorrência do cônjuge casado pelo regime da

\footnotetext{
${ }^{84}$ STJ. 992749/MS, Rel. Min. Nancy Andrighi, Brasília, $1^{\circ}$ de dezembro de 2009.

${ }^{85}$ Projeto de Lei 1792/2007 "Art. 1o. Esta lei exclui o cônjuge sobrevivente da condição de herdeiro necessário, se casado com o falecido no regime da separação de bens, obrigatório ou convencional. Art. 2o. O inciso I do art. 1.829 da Lei no 10.406, de 10 de janeiro de 2002, passa a vigorar com a seguinte redação: Art. 1.829.I - aos descendentes, em concorrência com o cônjuge sobrevivente, salvo se casado este com o falecido no regime da comunhão universal, ou no da separação de bens, obrigatório ou convencional; ou se, no regime da comunhão parcial, o autor da herança não houver deixado bens particulares;Art.3o. Esta lei entra em vigor na data de sua publicação."

${ }^{86}$ DE CARVALHO, Luiz Paulo Vieira. Direito Civil: questões fundamentais e controvérsias na parte geral, no direito de família e no direito das sucessões. $4^{\mathrm{a}}$ ed. Rio de Janeiro: Impetus, 2010. p. 288.
} 
separação obrigatória de bens prevista no artigo 1.641 do Código Civil (REsp. $n^{\text {o }}$ 1.382.170/SP, AgRg no REsp. n ${ }^{\text {o }}$ 1.334.340/MG, AgRg nos EREsp. $n^{\circ} 1.472 .945 / R J$, REsp. $n^{\circ} 1.382 .170 /$ SP, REsp. $n^{\circ} 1.430 .763$, REsp. $\left.\mathrm{n}^{\mathrm{o}} 1.346 .324\right)$.

O Ministro João Otávio de Noronha finalizou o seu voto, no REsp. $\mathrm{n}^{\mathrm{o}} 1.382 .170 / \mathrm{SP}$, ressaltando:

"Não concordo também com a interpretação dada ao art. 1.829, I, do Código Civil pela qual se afasta a possibilidade de o cônjuge casado no regime de separação convencional de bens concorrer com o descendente na sucessão do falecido. [...] se a lei fez algumas ressalvas quanto ao direito de herdar em razão do regime de casamento ser o de comunhão universal ou parcial, ou de separação obrigatória, não fez nenhuma quando o regime escolhido for o de separação de bens não obrigatório, de forma que, nessa hipótese, o cônjuge casado sob tal regime, bem como sob comunhão parcial na qual não haja bens comuns, é exatamente aquele que a lei buscou proteger, pois, em tese, ele ficaria sem quaisquer bens, sem amparo, já que, segundo a regra anterior, além de não herdar (em razão da presença de descendentes) ainda não haveria bens a partilhar., ${ }^{87}$

No mesmo sentido, Ana Luiza Nevares defende o direito à

concorrência do cônjuge casado pelo regime da separação convencional:

"A incomunicabilidade de patrimônios, portanto, não deixa de ser pressuposto do regime de separação de bens apenas porque o cônjuge nessa hipótese é herdeiro necessário. A sucessão causa mortis não tem o condão de tornar comuns patrimônios separados, estabelecendo a divisão da herança consoante a ordem de vocação hereditária, que contempla o cônjuge sobrevivente exatamente porque este mantém com o falecido estreito vínculo de solidariedade.

Além disso, a condição de herdeiro necessário do cônjuge casado no regime da separação convencional de bens quando em concorrência com os descendentes não fere o princípio da liberdade, já que não se pode dizer que todos aqueles que se casam por dito regime matrimonial pretendem que o seu consorte seja excluído da sucessão hereditária." ${ }^{" 88}$

Como efeito, em respeito à vontade manifestada pelo de cujus em vida, ao meu ver, o posicionamento mais acertado seria aquele que exclui o cônjuge casado pelo regime de separação de bens da sucessão de seu

\footnotetext{
${ }^{87}$ STJ. REsp. $\mathrm{n}^{\mathrm{o}}$ 1.382.170-SP, Rel. Min. João Otávio de Noronha, Brasília, 22 de abril de 2015.

${ }^{88}$ NEVARES, Ana Luiza Maia. A sucessão do cônjuge e do companheiro na perspectiva do direito civil-constitucional. $2^{\mathrm{a}}$ ed. São Paulo: Atlas, 2015. p.104-105.
} 
consorte. Não há que se falar em comunicabilidade após a morte, quando em vida o regime escolhido foi o da incomunicabilidade.

Além disso, se o de cujus quiser deixar uma parcela de seu patrimônio para o consorte sobrevivente, basta a elaboração de um testamento contendo essa disposição.

Por sua vez, no que tange ao regime de separação obrigatória, conforme demonstrado no capítulo I, na minha opinião, a posição mais coerente seria no sentido de aplicar a súmula $n^{\circ} 377$ do Supremo Tribunal Federal, a fim de amenizar os efeitos do regime.

Por fim, o legislador não fez qualquer menção ao regime de participação final nos aquestos no artigo 1.829, I, do Código Civil, gerando controvérsia.

Diante disso, Rolf Madaleno entende que, assim como no regime da comunhão universal, o cônjuge sobrevivente casado pelo regime de participação final nos aquestos deve ser excluído da sucessão, já que a meação seria suficiente para protegê-lo financeiramente:

\begin{abstract}
"Na comunhão parcial, o cônjuge casado e que fica viúvo, receberá em concurso hereditário com os descendentes ou ascendentes do sucedido uma quota dos bens particulares do falecido e aparentemente não irá receber nada de herança se o casamento foi realizado pelo regime da participação final de aquestos, pois dissolvido o casamento pelo evento morte, o regime que era de total separação de bens se transforma em comunhão parcial. Transformando-se em comunhão parcial, são aquestos todos os bens adquiridos onerosamente durante o casamento e ingressam na meação, mas não se comunicam no direito sucessório, já que o regime não foi lembrado no art. 1.829, inciso I do novo Código Civil." $" 89$
\end{abstract}

No entanto, a doutrina majoritária possui entendimento no sentido contrário, ou seja, de que o cônjuge sobrevivente casado pelo regime de participação final nos aquestos deve suceder em concorrência com os descendentes do autor da herança. Seguindo essa corrente, Maria Berenice entende que, como nada disse o legislador, não se pode restringir direitos por analogia:

\footnotetext{
${ }^{89}$ MADALENO, Rolf. O Novo Direito Sucessório Brasileiro. Disponível em:http://www.rolfmadaleno.com.br/novosite/conteudo.php?id=42Acessado em 28.09.2015
} 


\begin{abstract}
"Tanto no regime da comunhão parcial como no da participação final dos aquestos, os bens adquiridos na constância do casamento são bens particulares e não integram a meação do consorte. Em ambas as hipóteses, é partilhado o patrimônio comum adquirido durante $o$ casamento. Como no regime de participação final nos aquestos não está referido entre as exceções que afastam o direito de concorrência, seria necessário atribuir ao cônjuge sobrevivente parcela da herança. Havendo ou não bens particulares, participaria da sucessão com o $\mathrm{s}$ herdeiros. A regra é a concorrência, e a lei, ao excluí-la em alguns regimes de bens, não excepciona o da participação final nos aquestos. $\mathrm{E}$, para excluir direitos, é indispensável expressa previsão legal. Não dá para subtrair direitos por analogia." 90
\end{abstract}

No mesmo sentido, está o enunciado $\mathrm{n}^{\circ} 270$ da III Jornada de Direito Civil, segundo o qual o cônjuge casado pelo regime de participação final nos aquestos só herda se o autor da herança tiver deixado bens particulares. $^{91}$

Ao meu ver, o mais lógico seria aplicar ao cônjuge casado pelo regime de participação final nos aquestos a mesma regra aplicada ao cônjuge casado pelo regime da comunhão parcial, já que com a morte, o regime deixa de seguir as regras da separação convencional e passa a seguir as regras da comunhão parcial de bens.

No julgamento do REsp. $\mathrm{n}^{\circ}$ 54.567/PE, de relatoria do ministro Massami Uyeda, a Terceira Turma do Superior Tribunal de Justiça entendeu que o cônjuge casado pelo regime da participação final nos aquestos pode herdar os bens particulares do autor da herança, nas hipóteses do artigo 1.829 do Código Civil. ${ }^{92}$ Porém, tendo em vista a pouca aderência à esse regime de bens, não existe muita jurisprudência sobre o tema.

\footnotetext{
${ }^{90}$ DIAS, Maria Berenice. Manual das Sucessões. $3^{\text {a }}$ ed. São Paulo: Editora dos Tribunais, 2013. p.171.

${ }_{91}$ Enunciado $\mathrm{n}^{\circ} 270$ da III Jornada de Direito Civil: Art. 1.829: O art. 1.829, inc. I, só assegura ao cônjuge sobrevivente o direito de concorrência com os descendentes do autor da herança quando casados no regime da separação convencional de bens ou, se casados nos regimes da comunhão parcial ou participação final nos aquestos, o falecido possuísse bens particulares, hipóteses em que a concorrência se restringe a tais bens, devendo os bens comuns (meação) ser partilhados exclusivamente entre os descendentes.

${ }^{92}$ TUCCI, José Rogério Cruz. Jurisprudência sobre sucessão do cônjuge é instável. Disponível em http://www.conjur.com.br/2013-dez-10/paradoxo-corte-jurisprudencia-sucessao-conjuge-instavel. Acessado em 28.09.2015.
} 


\subsubsection{Quinhão mínimo do cônjuge em concorrência com descendentes}

Reconhecido o direito à concorrência do cônjuge sobrevivente com os descendentes, no momento da partilha do monte hereditário, deve-se observar a regra do artigo 1.832 do Código Civil ${ }^{93}$.

Segundo esse dispositivo, caberá ao cônjuge sobrevivente, em concorrência com os descendentes, quinhão igual ao dos que sucederem por direito próprio, por cabeça. Contudo, a quota do cônjuge não poderá ser inferior à quarta parte da herança, se ele for ascendente dos herdeiros com que concorre.

Assim, se o casal possui três filhos comuns e um dos cônjuges falece, a partilha se faz por cabeça entre o cônjuge sobrevivente e os descendentes, dividindo-se a herança em partes iguais. No entanto, se houver quatro descendentes ou mais, a herança será dividida em 4 partes, de modo que $1 / 4$ caberá ao cônjuge sobrevivente e os outros $3 / 4$ serão divididos entre os descendentes.

Por conseguinte, quando o cônjuge sobrevivente concorrer com descendentes do qual não é ascendente, a herança será dividida por cabeça, em partes iguais, já que o dispositivo não prevê a garantia da quota mínima pra o cônjuge sobrevivente que não é ascendente dos descendentes com quem concorre.

Como se vê, o artigo 1.832 do Código Civil não previu a situação em que o cônjuge sobrevivente é ascendente de apenas alguns dos descendentes com quem concorre, ou seja, quando, além dos descendentes comuns, há outros que são filhos apenas do autor da herança.

Tendo em vista que o legislador declarou que o cônjuge sobrevivente só teria direito à quota mínima quando for ascendente de todos os descendentes com os quais concorre, a doutrina majoritária entende que,

\footnotetext{
93“Art. 1.832. Em concorrência com os descendentes (art. 1.829, inciso I) caberá ao cônjuge quinhão igual ao dos que sucederem por cabeça, não podendo a sua quota ser inferior à quarta parte da herança, se for ascendente dos herdeiros com que concorrer."
} 
nesse caso, a herança será dividida por cabeça, recebendo o cônjuge quinhão igual ao dos demais descendentes.

Nas palavras de Mario Roberto:

"A contrario sensu, não sendo [o cônjuge sobrevivente] ascendente de todos os herdeiros que concorrer, não faz jus àquele benefício. A interpretação deve ser restritiva e, sendo a classe dos descendentes a primeira beneficiada na ordem de vocação hereditária, não deve o descendente, nos casos omissos, ser preterido pelo cônjuge, que ocupa a terceira posição na ordem de vocação hereditária." ${ }^{.94}$.

Esse também foi o entendimento dos juristas reunidos na $\mathrm{V}$ Jornada de Direito Civil, que aprovaram o enunciado 526, com a seguinte redação:

“Art. 1.832: Na concorrência entre o cônjuge e os herdeiros do de cujus, não será reservada a quarta parte da herança para o sobrevivente no caso de filiação hibrida." ${ }^{95}$

Dessa forma, o cônjuge sobrevivente só possui direito à quinhão mínimo quando concorrer com descendentes dos quais é ascendente.

\subsection{O CÔNJUGE EM CONCORRÊNCIA COM OS ASCENDENTES}

Se não houver herdeiros na classe dos descendentes, seguindo a ordem de vocação hereditária, os ascendentes serão chamados à sucessão, nos termos do artigo 1.829, inciso II, do Código Civil.

Assim como o inciso I, o inciso II do dispositivo prevê a concorrência do cônjuge com os ascendentes. Porém, diferentemente do inciso I, o legislador não fez qualquer menção aos regimes de bens na concorrência do cônjuge com os ascendentes.

Entendeu-se, portanto, que, havendo legitimidade do cônjuge sobrevivente para herdar, este concorre com os ascendentes do de cujus independentemente do regime de bens.

\footnotetext{
${ }^{94}$ FARIA, Mario Roberto Carvalho de. Direito das Sucessões: teoria e prática. $7^{\mathrm{a}}$ ed. Rio de Janeiro: Forense, 2013. p. 99

${ }^{9595}$ Enunciados aprovados nas I, III, IV e V Jornadas de Direito Civil. Disponível em:http://www.cjf.jus.br/CEJ-Coedi/jornadas-cej/enunciados-aprovados-da-i-iii-iv-e-v-jornada-dedireito-civil/compilacaoenunciadosaprovados1-3-4jornadadircivilnum.pdf. Acessado em 21.09.2015.
} 
Nesse caso, a partilha dos bens deixados pelo falecido deverá ser feita de acordo com o artigo 1.837 do Código Civil, ou seja, respeitando a quota mínima do cônjuge sobrevivente.

Segundo o dispositivo, quando o cônjuge sobrevivente concorrer com o pai e a mãe do de cujus, a herança deverá ser partilhada em três quinhões, cabendo um terço para cada herdeiro.

Porém, caso o cônjuge sobrevivente concorra com apenas um dos ascendentes em primeiro grau ou com ascendentes de graus mais remotos, o viúvo terá direito à metade da herança, sendo a outra metade partilhada entre os outros herdeiros.

Importante lembrar, neste ponto, que a sucessão dos ascendentes deve respeitar a regra do artigo 1.836 do Código Civil. Assim, se, por exemplo, o de cujus deixou apenas uma viúva, avós paternos e avós maternos, metade da herança caberá ao cônjuge sobrevivente e a outra metade deverá ser repartida em partes iguais pelos quatro avós.

Conforme apontado acima, não existe direito de representação na sucessão dos ascendentes, por isso, caso o de cujus deixe um cônjuge, pai e um avô, apenas o cônjuge e o pai serão herdeiros. $\mathrm{O}$ avô fica excluído da sucessão.

Não se pode esquecer, também, que o direito de concorrência e o direito à meação são distintos, de modo que, caso o cônjuge possua direito à meação em decorrência do regime de bens, ainda assim poderá concorrer com os ascendentes do de cujus, fazendo jus à quota mínima prevista pelo artigo 1.837 do Código Civil.

\subsection{O CÓNJUGE COMO HERDEIRO ÚNICO}

$\mathrm{Na}$ ausência de descendentes e ascendentes, seguindo a ordem de vocação hereditária do artigo 1.829 do Código Civil, o cônjuge é chamado à sucessão. 
Nos termos do artigo 1.838 do Código Civil, preenchidos os requisitos de legitimidade do artigo 1.830, o cônjuge sobrevivente será herdeiro único, excluindo os parentes colaterais e fazendo jus a totalidade da parte legítima da herança, quando o autor da herança não tiver deixado descendentes ou ascendentes.

Isto porque, nas palavras de Gustavo Tepedino, Heloisa Barboza e Maria Celina Bodin de Moraes, "o cônjuge sobrevivente é herdeiro necessário (artigo. 1.845) e tem assegurada a legítima, constituída por metade dos bens da herança" ${ }^{\text {"96. }}$.

Portanto, além do direito à meação, quando cabível, caso o autor não tenha deixado testamento, não havendo herdeiros necessários das classes previstas pelos incisos I e II do artigo 1.829 do Código Civil, o cônjuge sobrevivente fará jus à totalidade da herança do de cujus, incluindo a legitima e a parte disponível.

\subsection{O CÔNJUGE E O DIREITO REAL DE HABITAÇÃO}

Além de sua quota como herdeiro, independentemente do regime de bens, o artigo 1.831 do Código Civil prevê, também, para o cônjuge sobrevivente o direito real de habitação, a fim de assegurar o seu direito constitucional de moradia (artigo $6^{\circ}$, caput, da Constituição Federal).

O direito real de habitação é garantido ao viúvo, sem prejuízo da participação que lhe caiba na herança, desde que o imóvel em questão seja o único destinado à residência familiar a inventariar.

Em outras palavras, esse direito pressupõe que haja somente um imóvel residencial no acervo hereditário. Dessa forma, caso o autor da herança tenha deixado um único imóvel residencial, porém nele não morar o cônjuge, não há que se falar em direito real de habitação.

\footnotetext{
${ }^{96}$ TEPEDINO, Gustavo et al.. Código Civil Interpretado: Conforme a Constituição da República, vol. IV. $1^{\text {a }}$ ed. Rio de Janeiro: Renovar, 2014. p.647.
} 
Seguindo a mesma lógica, quando houver mais de um imóvel residencial no monte hereditário, não há que se falar em direito real de habitação, já que parte desses imóveis ou até mesmo a integralidade de um deles caberá ao supérstite, a título de herança.

No entanto, condicionar o direito real de habitação à existência de um único imóvel residencial no acervo, pode levar à uma situação de completo desamparo do cônjuge sobrevivente que não é meeiro nem herdeiro, como ocorre quando o regime de bens é o da separação obrigatória de bens. Nessa hipótese, caso o autor da herança tenha mais de um imóvel residencial, além de não receber herança, nem meação, o viúvo ainda perderá o seu lar, em razão da não incidência do direito real de habitação.

Diante da questão, Ana Luiza Maia Nevares propõe uma solução bastante interessante:

\begin{abstract}
"Melhor disciplina seria aquela em que o benefício incidisse sobre o imóvel destinado à residência da família, desde que seja o único dessa natureza a inventariar, quando há bens imóveis comuns entre os consortes ou o sobrevivente é herdeiro; não os havendo, ou não sendo o cônjuge supérstite herdeiro, a lei deveria prever a incidência do direito real de habitação sobre o imóvel que era destinado à residência da família, independentemente do número de imóveis presentes no acervo hereditário." ${ }^{" 97}$
\end{abstract}

Além disso, ainda que o imóvel sobre o qual incide o direito real de habitação venha a ser atribuído na partilha dos demais herdeiros, poderá o cônjuge sobrevivente titular desse direito usá-lo para sua moradia enquanto viver.

Com o Código Civil de 2002, o direito real de habitação passou a ser vitalício, independentemente do cônjuge sobrevivente contrair novas núpcias ou união estável, extinguindo-se apenas pela sua não utilização (artigo 1.410, inciso VIII, e 1.416 do Código Civil).

\footnotetext{
${ }^{97}$ NEVARES, Ana Luiza Maia. A sucessão do cônjuge e do companheiro na perspectiva do direito civil-constitucional. $2^{\mathrm{a}}$ ed. São Paulo: Atlas, 2015. p.110.
} 
A doutrina critica o artigo 1.831 no sentido de que não se atentou para as condições econômicas do cônjuge sobrevivente, que pode ter herdado grande acervo patrimonial, sem cessar automaticamente, contudo, o ônus real, quando o titular do direito real de habitação adquirir outro imóvel.

Ademais, podem ocorrer situações em que os descendentes menores do autor da herança, ou seus ascendentes idosos, por exemplo, sejam completamente dependentes financeiramente do autor da herança e, em razão do direito real de habitação, ficariam ainda mais desprotegidos patrimonialmente.

Com efeito, a jurisprudência brasileira leva em consideração essas situações peculiares, havendo julgados que indeferiram a concessão do direito real de habitação quando o cônjuge sobrevivente é proprietário de imóvel residencial, garantido seu direito constitucional de moradia (REsp. 1249227/SC, Rel. Min. Luís Felipe Salomão, j. 17/12/2013).

\subsection{QUAL REGIME DE BENS GARANTE O MAIOR ACERVO PATRIMONIAL PARA O CÔNJUGE SOBEVIVENTE?}

Após o estudo de todas as hipóteses de sucessão do cônjuge, verifica-se que, para responder a pergunta proposta acima, é preciso analisar a sucessão do cônjuge, em concorrência com os descendentes, já que em todas as outras situações o quinhão do cônjuge independe do regime de bens.

Nesse sentido, tendo em vista a jurisprudência do Superior Tribunal de Justiça, o cônjuge, em concorrência com os descendentes, se casado pelo regime da:

(i) separação convencional de bens, herdará sobre todos os bens;

(ii) comunhão parcial, terá direito à metade dos bens comuns e direitos sucessórios sobre os bens particulares; 
(iii) comunhão universal, terá apenas direito à meação sobre os bens comuns;

(iv) separação legal, se reconhecida a aplicabilidade da súmula 377 do Supremo Tribunal Federal, terá direito à metade dos bens adquiridos onerosamente na constância do casamento; e

(v) participação final dos aquestos, terá os mesmos direito que o cônjuge casado pelo regime de comunhão parcial.

Como se vê, em todos os regimes de bens o cônjuge sobrevivente terá direito aos bens comuns, seja pelo direito à meação, seja por direitos sucessórios. Assim, para analisar qual regime permite o maior acervo patrimonial é preciso verificar a quantidade de bens particulares, bem como a quantidade de filhos que o de cujus deixou. Vejamos.

Desde logo, é possível afirmar que o regime que garante o maior acervo patrimonial para o cônjuge sobrevivente é o da comunhão total de bens, já que o cônjuge terá direito, independentemente da quantidade de filhos, à metade dos bens comuns que, em regra, representam o totalidade do patrimônio do de cujus. Excepcionalmente, se o de cujus deixar uma parcela significativa de bens particulares - como bens recebidos por doação com cláusula de incomunicabilidade -, a comunhão total seria menos vantajosa do que a comunhão parcial, pois neste regime, além do direito à meação, o cônjuge sobrevivente também teria direito a uma parcela dos bens particulares.

Em seguida, tendo em vista o disposto acima, é possível verificar que, em regra, o cônjuge casado pelo regime da comunhão parcial de bens, em concorrência com os descendentes, terá direito a um acervo patrimonial maior do que o cônjuge casado pelo regime da separação convencional, na mesma situação.

Essa conclusão surge da comparação dos dois regimes, eis que o cônjuge casado pelo regime da separação convencional teria apenas direito à uma parcela da totalidade dos bens do de cujus, enquanto que o casado 
pelo regime da comunhão parcial teria direito não só a uma parcela dos bens particulares, mas também à metade dos bens comuns (direito à meação).

No que tange ao regime da separação obrigatória, se reconhecida a aplicação da súmula $n^{\circ} 377$ do Supremo Tribunal Federal, o cônjuge teria direito a metade dos bens adquiridos na constância do casamento, a titulo oneroso.

Ocorre que, na maioria dos casos, o regime de separação obrigatória é imposto aos nubentes que possuem mais de 70 anos, de modo que o direito à meação só incide sobre os bens adquiridos onerosamente durante esse período, ou seja, não engloba grande parte do patrimônio do de cujus, construído ao longo de sua vida.

Ademais, não fosse pela súmula $\mathrm{n}^{\circ} 377$ do Supremo Tribunal Federal, que the garantiu o direito à meação, o cônjuge casado pelo regime da separação obrigatória não teria direito à nada, conforme a legislação vigente. Portanto, apesar de ser o regime menos benéfico, só o fato do cônjuge sobrevivente ganhar alguma parcela dos bens já representa uma grande vantagem.

Por fim, não se mostra necessário mencionar o regime da participação final nos aquestos, pois aos cônjuges casados por esse regime se aplicam as mesmas regras da comunhão parcial.

Cabe destacar, ainda, que o número de descendentes influência na análise final sobre o regime de bens mais benéfico economicamente, pois a massa de bens sobre a qual o cônjuge possui direitos sucessórios deverá ser dividida entre todos os herdeiros. No entanto, no momento da divisão dos quinhões, não se pode esquecer que o cônjuge sobrevivente tem direito à uma quota mínima de $1 / 4$ do monte hereditário, independentemente do regime de bens, conforme previsto pelo artigo 1.832, do Código Civil.

Importante atentar para o fato de que, por ser um direito próprio, o número de filhos deixados pelo autor da herança não influência no direito à meação. Em outras palavras, quando o regime de bens garantir o direito à 
meação, o cônjuge sobrevivente terá direito à metade dos bens do falecido, independentemente do número de filhos.

Por fim, é importante frisar que a análise do regime de bens mais benéfico economicamente para o cônjuge sobrevivente deve ser feita caso a caso, já que, para calcular o acervo patrimonial destinado ao cônjuge, será necessário observar diversas peculiaridades, entre elas as proporções de bens comuns e particulares e a quantidade de filhos que o autor da herança deixou. 


\title{
4.1 CRÍTICAS AO ARTIGO 1.790, DO CÓDIGO CIVIL: O COMPANHEIRO É HERDEIRO NECESSÁRIO?
}

A sucessão do companheiro, no Código Civil, está regulada pelo artigo 1.790, situado nas Disposições Gerais do Direito Sucessório (Título I da Sucessão Geral). A doutrina critica duramente a sua inserção nesse título, argumentando que o dispositivo estaria melhor localizado dentro do Título II, que trata da sucessão legítima e da ordem de vocação hereditária, decorrentes dos vínculos familiares.

Essa organização se deve ao fato de que, conforme exposto acima, o Projeto de Código Civil, aprovado em 1984, não possuía qualquer previsão sobre os direitos sucessórios do companheiro, razão pela qual foi feita uma emenda ao Projeto para suprir essa lacuna, criando-se, assim, o artigo 1.790 do Código Civil.

Nesse sentido, Gustavo Tepedino, Heloisa Barboza e Maria Celina Bodin de Moraes explicam:

\begin{abstract}
“A inserção da matéria no capítulo das 'disposições gerais', em dispositivo que desafia o intérprete, merece especial atenção, posto que, se por um lado não afasta a aplicação dos princípios e regras específicos da sucessão legítima, por outro, exige interpretação cuidadosa para que não haja prejuízo aos interessados." 98
\end{abstract}

No que tange a esses possíveis prejuízos, os autores identificam, por exemplo, a discussão que se instaurou quanto à classificação do companheiro como herdeiro necessário ou não.

Essa controvérsia, amplamente debatida pela doutrina, surge não apenas em razão do companheiro não estar no rol dos herdeiros necessários do artigo 1.845 do Código Civil, mas também por não estar contemplado no

\footnotetext{
${ }^{98}$ TEPEDINO, Gustavo et al.. Código Civil Interpretado: Conforme a Constituição da República, vol. IV. $1^{\mathrm{a}}$ ed. Rio de Janeiro: Renovar, 2014. p.540.
} 
rol do artigo 1.829, do Código Civil, que prevê a ordem de vocação hereditária.

No entanto, o artigo 1.850, do Código Civil, só permite que o testador exclua os colaterais da sucessão, não mencionando o companheiro sobrevivente, o que corrobora para a tese de que ele é herdeiro necessário.

A doutrina majoritária, em uma interpretação sistemática e conforme o artigo 266 da Constituição Federal, entende que o companheiro deve ser considerado herdeiro necessário, e não apenas facultativo.

Esse entendimento garante maior proteção ao companheiro que, além de não poder ser excluído da sucessão de seu consorte por disposição testamentária, também herdará a totalidade dos bens de seu consorte quando não existirem outros parentes sucessíveis, impedindo, assim, que a herança seja considerada vacante.

Sobre a controvérsia, Gustavo Tepedino, Maria Celina Bodin de Morais e Heloisa Barboza defendem:

"não parece razoável excluir o companheiro do rol de herdeiros necessários, apenas por não ter sido mencionado expressamente no rol do artigo em análise [artigo 1.829 do Código Civil]. Ainda que não tivessem fundamento constitucional o direito sucessório do companheiro, o artigo 1.790 tem natureza imperativa, deixando evidente que não se trata apenas de herdeiro legítimo que não pode ser afastado da sucessão, nos termos ali previstos."

No mesmo sentido, Maria Berenice Dias:

"No momento em que foi assegurado também ao companheiro o direito
de concorrência, ele acabou por ser elevado à condição de herdeiro
necessário com relação a fração da herança que recebe juntamente com os
herdeiros que o antecedem na ordem de vocação hereditária.""

Apesar do entendimento da doutrina majoritária ser esse, ainda existem algumas vozes isoladas, como José Luiz Gavião de Almeida, que, sob o argumento de que a restrição da liberdade de testar só pode ser admitida para contemplar os herdeiros enumerados pela lei, acreditam que

\footnotetext{
${ }^{99}$ DIAS, Maria Berenice. Manual das Sucessões. $3^{\text {a }}$ ed. São Paulo: Editora dos Tribunais, 2013. p.184.
} 
os companheiros não devem ser classificados como herdeiros necessários. $^{100}$

Pelo exposto, o companheiro é considerado herdeiro necessário, não podendo ser afastado da sucessão por disposição testamentária. Assim, quando houver companheiro sobrevivente, o testamento só poderá dispor sobre metade da massa dos bens adquiridos onerosamente na vigência da união estável que couber ao autor da herança, ou seja, 1/4 do total dos bens comuns (artigo 1.789 do Código Civil). Assim, o companheiro só será excluído da sucessão de seu consorte se deserdado, na forma do artigo 1.961, do Código Civil.

Essas são algumas críticas gerais destinadas ao artigo, as demais, por serem pontuais, serão comentadas em momento oportuno. Conforme se verá adiante, a doutrina e a jurisprudência têm feito grande esforço no sentido de construir interpretações que amenizem os efeitos negativos do dispositivo.

\subsection{MASSA DE BENS SOBRE A QUAL INCIDEM OS DIREITOS SUCESSÓRIOS DO COMPANHEIRO}

Em seu caput, o artigo 1.790, do Código Civil, prevê que o direito sucessório do companheiro incide apenas sobre os bens adquiridos onerosamente na constância da união estável. Assim, antes de iniciar a partilha dos bens do falecido, será necessário diferenciar os bens adquiridos onerosamente na vigência da união estável, dos adquiridos à título gratuito ou antes da relação. Desse modo, serão criadas duas ordens de vocação hereditária, já que aqueles serão regulados pelo artigo 1.790 do Código Civil, enquanto que sobre estes incidirão as regras do artigo $1.829 \mathrm{e}$ seguintes.

\footnotetext{
${ }^{100}$ ALMEIDA, José Luiz Gavião de. Comentários ao Código Civil, vol. XXIII. São Paulo: Atlas, 2009. P. 252 apud TEPEDINO, Gustavo et al.. Código Civil Interpretado: Conforme a Constituição da República, vol. IV. $1^{\mathrm{a}}$ ed. Rio de Janeiro: Renovar, 2014. p.656.
} 
Muitos autores argumentam a inconstitucionalidade desse dispositivo. Luiz Paulo Vieira encontra, pelo menos, duas inconstitucionalidades, a discriminação do companheiro em relação ao cônjuge:

\begin{abstract}
"No caput deste art. 1.790, o legislador está cometendo, no meu entender, ao menos duas inconstitucionalidades. A primeira delas, ao discriminar o companheiro e/ou companheira na união estável quanto aos direitos sucessórios, comparativamente ao cônjuge sobrevivente, ferindo o princípio da igualdade, pois a família de qualquer natureza deve ter idêntica proteção constitucional, com simetria de direitos (arts. $1^{\circ}$, III; $5^{\circ}$, caput, e seu inc. XXX, c/c art. 226, caput e seu $\S 3^{\circ}, 1^{\mathrm{a}}$ parte, da Constituição Federal), sabendo-se que o cônjuge recolhe seu quinhão sobre todos os bens integrantes do acervo hereditário adquiridos onerosamente ou não. [...] ao menos em relação ao conteúdo jurídico dos efeitos emanados pela formação de ambas as famílias deve haver uma salutar igualdade civil-constitucional, com base no princípio da isonomia." $" 101$
\end{abstract}

E, ainda, a segunda inconstitucionalidade se dá pelo fato da lei conferir, em algumas situações de concorrência com os descendentes, mais direitos sucessórios ao companheiro do que às pessoas casadas pelos regimes da comunhão universal, separação obrigatória ou comunhão parcial de bens.

Isto porque, as pessoas casadas por aqueles dois primeiros regimes sequer participam da sucessão, já que possuem direito de meação, o que seria suficiente para garanti-la economicamente, ou se casaram não observando as regras do Código Civil.

Em relação às pessoas casadas pelo regime da comunhão parcial de bens, tendo em vista que a doutrina majoritária entende que o cônjuge sobrevivente só teria direitos sucessórios sobre os bens particulares, quando o monte for composto apenas por bens comuns, o companheiro participará da sucessão, enquanto que o cônjuge ficará excluído. Essas situações gerariam desigualdade jurídica entre ambos e, portanto, o artigo seria inconstitucional.

\footnotetext{
${ }^{101}$ CARVALHO, Luiz Paulo Vieira de. Direito Civil: questões fundamentais e controvérsias na parte geral, no direito de família e no direito das sucessões. $4^{\mathrm{a}}$ ed. Rio de Janeiro: Impetus, 2010. p. $312-313$.
} 
Essa questão foi levada ao Superior Tribunal de Justiça no REsp. $\mathrm{n}^{\mathrm{o}}$ 1.291.636/DF, que suscitou arguição de inconstitucionalidade em relação ao artigo 1.790, caput, do Código Civil, por estabelecer situação mais vantajosa para o companheiro do que para o cônjuge. A arguição encontrase em mesa para julgamento pela Corte Especial desde 27/08/2015. Em seu voto, o relator Min. Luis Felipe Salomão ressalta essa questão:

"O caput do art. 1.790, por sua vez, segundo a exegese estabelecida pelo Tribunal a quo e contestada pelo Ministério Publico, confere direitos hereditários à companheira exatamente na fração do patrimônio que não seria aquinhoada pelo cônjuge, ou seja, no bens comuns, circunstancia que faz o companheiro ser herdeiro mesmo nas hipóteses em que não o seria o cônjuge, ou seja, quando não existirem bens particulares deixados pelo falecido."102

No mesmo sentido, a Ministra Nancy Andrighi deferiu o pedido de liminar na Medida Cautelar $\mathrm{n}^{\mathrm{o}}$ 14.509, determinando que os bens controvertidos não fossem partilhados, a fim de proteger o companheiro:

"Medida cautelar. Atribuição de efeito suspensivo a recurso especial. Inventário. De cujus que, após o falecimento de sua esposa, com quem tivera uma filha, vivia, em união estável, há mais de trinta anos com sua companheira, sem contrair matrimônio. Incidência, quanto à vocação hereditária, da regra do art. 1.790 do $\mathrm{CC} / 02$. Alegação, pela filha, de que a regra é mais favorável para a convivente que a norma do art. 1829, I, do $\mathrm{CC} / 02$, que incidiria caso o falecido e sua companheira tivessem se casado pelo regime da comunhão parcial.

Afirmação de que a Lei não pode privilegiar a união estável, em detrimento do casamento. Medida liminar parcialmente deferida, apenas para determinar a partilha, no inventário, da parcela incontroversa do patrimônio, promovendo-se reserva de bens.

- O art. 1.790 do CC/02, que regula a sucessão do 'de cujus' que vivia em união estável com sua companheira, estabelece que esta concorre com os filhos daquele na herança, calculada sobre todo o patrimônio adquirido pelo falecido durante a convivência. Trata-se de regra oposta à do art. 1.829 do $\mathrm{CC} / 02$, que, para a hipótese de ter havido casamento pela comunhão parcial entre o 'de cujus' e a companheira, estabelece que a herança do cônjuge incida apenas sobre os bens particulares.

- A diferença nas regras adotadas pelo código para um e outro regime gera profundas discrepâncias, chegando a criar situações em que, do ponto de vista do direito das sucessões, é mais vantajoso não se casar.

- A discussão quanto à legalidade da referida diferença é profundamente relevante, de modo que se justifica o deferimento da medida liminar pleiteada em ação cautelar, para o fim de reservar os bens controvertidos no inventário 'sub judice', admitindo-se a partilha apenas dos incontroversos. Medida liminar parcialmente deferida."

\footnotetext{
${ }^{102}$ STJ. REsp. no 1.291.636-DF, Rel. Ministro Luis Felipe Salomão, Brasília, 11 de junho de 2013.

${ }^{103}$ STJ. MC 14.509/SP. Rel. Ministra Nancy Andrighi, Brasília, 21 de agosto de 2008.
} 
Além disso, outra crítica bastante presente na doutrina se deve ao fato de que, dependendo da interpretação, esse artigo poderia gerar outras situações absurdas, como no caso em que o companheiro tenha adquirido todo seu patrimônio antes da união estável ou somente tenha adquirido bens à título gratuito e não haja outros parentes suscetíveis. Nesse caso, aparentemente, tendo em vista que a herança do de cujus é composta apenas por bens particulares, ela seria vacante e, portanto, ficaria por inteiro para o município, enquanto que o companheiro sobrevivente ficaria desamparado.

Com efeito, para evitar essa situação, é preciso fazer uma interpretação sistemática dos artigos 1.844 e 1.790, do Código Civil, de modo que, o companheiro, herdeiro único, terá direito a totalidade da herança, ainda que o de cujus tenha deixado apenas bens adquiridos à título gratuito ou antes da união estável, em detrimento do município.

Essa construção é feita a partir da redação do artigo 1.844, do Código Civil, que prevê que a herança só será destinada ao Município na ausência de cônjuge, companheiro ou qualquer outro parente sucessível. Assim, ainda que o caput do artigo 1.790 preveja expressamente que o companheiro só possui direito sucessório sobre os bens adquiridos onerosamente na vigência da união estável, não havendo outros herdeiros, ele será chamado à sucessão para herdar a totalidade do monte.

Com o intuito de solucionar essa problemática, Caio Mario da Silva Pereira defende que o termo "herança", presente nos incisos III e IV, do artigo 1.790, do Código Civil, deve ser interpretado de forma abrangente para englobar todos os bens deixados pelo autor da herança, inclusive os bens particulares:

Exatamente par evitar semelhante resultado é que (ao ver do atualizador deste volume) se deve interpretar a expressão "herança", constante dos $\mathrm{n}^{\text {os }}$ III e IV do art. 1.790, em seu sentido próprio, mais abrangente do que "bens adquiridos onerosamente na vigência da união estável" (caput). No rigor da boa técnica, o conteúdo do caput deveria ser comum a todas as hipóteses em que o dispositivo a seguir se desdobra; no caso específico, porém, se a "herança" de que tratam os no ${ }^{\text {os }}$ III e IV se limitar aos bens comuns (conforme sugere o caput), chegaríamos a situações de extrema iniquidade, como a de o de cujus que, sem parentes sucessíveis e 
sem haver feito testamento, houvesse vivido em união estável, durante longos anos, no curso dos quais não chegou a adquirir bens que tivessem comunicado ao companheiro. Não aprece razoável, em tais circunstâncias, ter por vacante a herança, destinando-a ao ente estatal, quando, entre duas possíveis interpretações de dispositivo acerca da sucessão legítima, há de se dar preferência àquela que maior proteção confira à família."

Ressalte-se, por oportuno, que, conforme explicado acima, tendo em vista que à união estável são aplicadas as regras do regime da comunhão parcial de bens, o companheiro tem direito à meação. Ou seja, metade dos bens comuns do casal integram o patrimônio do companheiro sobrevivente, por direito próprio, independentemente de qualquer direito sucessório. Portanto, além da meação, o companheiro sobrevivente também tem direitos hereditários sobre a outra metade dos bens comuns.

Como se vê, o artigo 1.790, do Código Civil, possui regra imperativa, de modo que, ainda que os companheiros realizem pacto de convivência estipulado regras de outro regime de bens, que não o da comunhão parcial, o companheiro sobrevivente herdaria na forma do dispositivo, de modo que o pacto não produziria efeitos sobre seus direitos sucessórios, esse é o entendimento de vários autores, conforme defende Maria Berenice:

\footnotetext{
"Mesmo que, por pacto de convivência, adotem o regime da separação convencional, persiste o direito do sobrevivente de concorrer sobre o que for adquirido onerosamente no período da união."105
}

Em sentido contrário, Mario Roberto afirma que "havendo contrato estipulando outra forma de divisão de bens, deverá ser dado conhecimento ao juízo do inventário, anexando-se cópia do mesmo" $" 106$.

\footnotetext{
${ }^{104}$ PEREIRA, Caio Mário da Silva. Instituições de Direito Civil: Direito das Sucessões, vol. VI. $21^{\mathrm{a}}$ ed. atualizado por Carlos Roberto Barbosa Moreira. Rio de Janeiro: Forense, 2014. p. 143.

${ }^{105}$ DIAS, Maria Berenice. Casar ou não casar? Dúvidas sobre questões sucessórias. Disponível em:http://mariaberenice.com.br/uploads/casar ou n\%E3o casar - si\%281\%29.pdf. Acessado em 05.10.2015

${ }^{106}$ FARIA, Mario Roberto Carvalho de. Direito das Sucessões: teoria e prática. $7^{\mathrm{a}}$ ed. Rio de Janeiro: Forense, 2013. p.139.
} 


\subsection{O COMPANHEIRO EM CONCORRÊNCIA COM OS DESCENDENTES}

A concorrência do companheiro com os descendentes do falecido está prevista nos incisos I e II, do artigo 1.790, do Código Civil. Segundo o primeiro inciso, quando o companheiro sobrevivente concorrer com filhos comuns, receberá uma quota igual à que, por lei, for atribuída ao filho. Por sua vez, se a concorrência ocorrer com descendentes só do autor da herança, o companheiro terá direito à metade do que couber a cada um daqueles, nos termos do inciso II.

Assim, se o companheiro sobrevivente teve dois filhos com o autor da herança, separada sua meação, a outra metade dos bens comuns deverá ser dividida em 3 quotas, cabendo 1/3 para cada filho e para o companheiro. Por sua vez, se o falecido deixou dois filhos de outra relação e um companheiro, separada sua meação, a ele caberá $1 / 5$ da outra metade dos bens comuns e $2 / 5$ para cada descendente.

Cabe destacar que, na sucessão do companheiro sobrevivente em concorrência com descendentes, não há que se falar em quota mínima, como ocorre na sucessão do cônjuge, previsto pelo artigo 1.832, do Código Civil. Como se vê, ao passo que o cônjuge sobrevivente nunca receberá menos do que os descendentes, o companheiro sobrevivente que concorra com descendentes apenas do autor da herança receberá quota equivalente à metade daquela que estes receberem. Diante disso, ou seja, da discrepância entre o tratamento sucessório conferido ao cônjuge e ao companheiro, muitos autores consideram esse artigo inconstitucional.

Para fazer o cálculo da quota do companheiro, em concorrência com descendentes apenas do autor da herança, basta utilizar a seguinte fórmula:

$$
y x+y x+x=\text { monte hereditário }
$$

sendo $\mathrm{y}=$ número de filhos e $\mathrm{x}=$ valor do quinhão do companheiro 
No cálculo, é atribuído o valor 1 para o companheiro e o valor 2 para cada descendente. Assim, ao final, deve-se dividir o valor a ser partilhado pela soma dos valores atribuídos aos herdeiros, de modo que o valor alcançado será equivalente à quota do companheiro sobrevivente e o dobro desse valor deve ser destinado a cada descendente.

Note-se que, ao utilizar a palavra "filhos" no inciso I do artigo, e "descendentes" no inciso II, o disposto permite interpretações divergentes, suscitando dúvidas quanto a sucessão do companheiro em concorrência com descendentes comuns, mas que não sejam filhos. Em outras palavras, na concorrência do companheiro com netos comuns, qual quota the caberia?

Se por um lado parte da doutrina, como Caio Maria da Silva Pereira, entende que é preciso interpretar extensivamente a expressão "filhos", do inciso I, para seja lida como "descendentes comuns", por outra há quem entenda que, na concorrência com descendentes comuns de graus mais remoto, o companheiro deve herdar na forma do inciso III do artigo 1.790, do Código Civil, que prevê a concorrência dele com outros parentes sucessíveis.

Essa controvérsia foi debatida na III Jornada de Direito Civil, resultando no enunciado $\mathrm{n}^{\circ} 266^{107}$, segundo o qual o companheiro, em concorrência com netos e outros descendentes comuns de grau mais remoto, deve herdar na forma do inciso I, de modo que a expressão "filhos" deve ser interpretada extensivamente para abranger todos os descendentes comuns. Essa corrente parece ser a mais coerente, já que os descendentes comuns de graus mais remoto herdam no lugar de seus pais, por direito próprio ou por direito de representação.

Nesse sentido, Ana Luiza Nevares argumenta:

"Realmente, a aplicação do inciso III à hipótese mencionada feriria a sistemática da lei, uma vez que não há razão para que os netos recebam

\footnotetext{
${ }^{107}$ Enunciado $\mathrm{n}^{\mathrm{o}}$ 266: Art. 1.790- Aplica-se o inc. I do art. 1.790 também na hipótese de concorrência do companheiro sobrevivente com outros descendentes comuns, e não apenas na concorrência com filhos comuns.
} 
quotas diferenciadas em relação aos filhos quando ambos sucedem por direito próprio. Nessa hipótese, os descendentes devem suceder da mesma forma, quer sejam filhos, netos, bisnetos etc." ${ }^{108}$

Além disso, também existe polêmica em relação à sucessão híbrida do companheiro em concorrência com descendentes comuns e exclusivos do autor da herança, já que neste ponto a lei foi omissa.

Para solucionar essa questão, Gisele Hironaka apresenta quatro propostas para conciliar os dois incisos:

(i) identificação dos descendentes como se todos fossem filhos comuns, aplicando-se apenas o inciso I;

(ii) identificação dos descendentes como se todos fossem filhos exclusivos do autor da herança, aplicando-se apenas o inciso II;

(iii) a composição dos incisos I e II, atribuindo ao companheiro sobrevivente uma cota e meia; ou

(iv) composição dos incisos I e II para subdivisão proporcional da herança, segundo a quantidade de descendentes existentes de cada grupo.

Há, ainda, uma quinta solução proposta pela doutrina, qual seja promover a sucessão do companheiro e dos descendentes comuns e exclusivos nos termos do inciso III, do artigo 1.790, do Código Civil, como se todos os descendentes fossem considerados outros parentes sucessíveis.

A doutrina majoritária entende ser mais razoável aplicar o inciso I, do artigo 1.790, do Código Civil, a todos os descendentes, já que a partilha por cabeça deve ser feita em igualdade de condições para todos os herdeiros, sob pena conferir diferentes direitos sucessórios aos descendentes a depender de sua origem, o que violaria o artigo $227, \S 6^{\circ}$, da Constituição Federal.

\footnotetext{
${ }^{108}$ NEVARES, Ana Luiza Maia. A sucessão do cônjuge e do companheiro na perspectiva do direito civil-constitucional. $2^{\mathrm{a}}$ ed. São Paulo: Atlas, 2015. p.117.
} 
Além disso, no inciso II, o legislador utilizou a expressão "se concorrer com descendentes só do autor da herança", o que leva a conclusão de que "a restrição patrimonial alcança o companheiro sobrevivente apenas quando concorrer sucessoriamente com prole exclusiva do autor da herança" ${ }^{\text {"109 }}$. Essa corrente é defendida por autores como Ana Luiza Nevares, Silvio Venosa, Caio Maria da Silva Pereira, Guilherme Calmon da Silva Pereira, Gustavo Tepedino, Maria Celina Bodin de Moraes, Heloisa Barboza e Luiz Paulo Vieira de Castro.

Em sentido contrário, alguns autores defendem que a sucessão híbrida deveria seguir a lógica do inciso II, do dispositivo, sob o fundamento de que, com a aplicação do inciso I, o patrimônio do de cujus mudaria de linhagem, uma vez que o que foi transmitido hereditariamente ao companheiro sobrevivo se destinaria, por ocasião de seu óbito, apenas aos seus herdeiros, e não mais aos do autor da primeira herança. Seguindo essa lógica, o inciso II beneficiaria a perpetuação dos bens dentro da mesma linhagem, pois a herança estaria maior concentrada nos descendentes exclusivos do autor da herança.

\subsection{O COMPANHEIRO EM CONCORRÊNCIA COM OUTROS PARENTES}

O inciso III, do artigo 1.790, do Código Civil, estabelece que o companheiro sobrevivente terá direito a um terço da herança quando concorrer com outros parentes sucessíveis.

A primeira dúvida que surge em relação a esse dispositivo é: quais são os outros parentes sucessíveis? De acordo com a sistemática do ordenamento jurídico brasileiro (artigos 1.829 e 1.592 do Código Civil), não havendo descendentes, o companheiro concorrerá com os ascendentes e

\footnotetext{
${ }^{109}$ CARVALHO, Luiz Paulo Vieira de. Direito Civil: questões fundamentais e controvérsias na parte geral, no direito de família e no direito das sucessões. $4^{\circ}$ ed. Rio de Janeiro: Impetus, 2010. p. 322 .
} 
colaterais até o $4^{\circ}$ grau. Sendo certo que a convocação dos parentes colaterais só poderá ocorrer quando o de cujus não tiver deixado ascendentes, seguindo a mesma ordem do artigo 1.829, do Código Civil.

Neste ponto reside mais uma crítica ao dispositivo, uma vez que na vigência do sistema anterior, conforme previsto pelo artigo $2^{\circ}$, inciso III, da Lei $n^{0} 8.971 / 94$, na ausência de descendentes e ascendentes, o companheiro era herdeiro único, excluindo os parentes colaterais.

Atente-se, também, para o fato de que esse dispositivo pode deixar os colaterais em situação bem mais vantajoso do que a do companheiro sobrevivente, já que, dependendo da massa de bens deixada pelo de cujus, pode ocorrer dos parentes colaterais herdarem não só dois terços da metade dos bens comuns, mas também a totalidade dos bens particulares.

Essa questão foi analisada pelo Superior Tribunal de Justiça em três oportunidades distintas, sendo suscitadas arguições de inconstitucionalidade do dispositivo (REsp. $n^{\circ} 1.135 .354 / P B$, REsp. $n^{\circ} 1.291 .636 /$ DF e REsp. $n^{\circ}$ 1.318.249/GO) em todas as ocasiões. Diante disso, a arguição suscitada no REsp. $\mathrm{n}^{\mathrm{o}}$ 1.135.354/PB, que já estava em trâmite, foi sobrestada até a conclusão dos incidentes de inconstitucionalidade dos outros Recursos Especiais.

Em seu voto, no REsp. $n^{\circ}$ 291.636/DF o Ministro Luis Felipe Salomão argumentou:

\footnotetext{
"Como se vê, nos termos dos incisos III e IV, à falta de descendentes, a companheira concorre com os demais 'parentes sucessíveis' do falecido, categoria na qual se inserem, por força dos arts. 1.592 e 1.839 do Código Civil, os colaterais até o quarto grau, como os primos do falecido e os chamados 'tio-avồ' e 'sobrinho-neto'.

Pior que isso, como se não bastasse a simples concorrência, quando os mencionados colaterais até o quarto grau são chamados a suceder junto com a companheira, ocupam inexplicável posição de superioridade, pois irão aquinhoar $66,66 \%$ da herança, contra os $33,33 \%$ restantes que tocará à companheira.

Em uma união estável de 30 anos, por exemplo, da qual não adviessem filhos, e também inexistindo ascendentes vivos do de cujus, chamar um primo ou um 'tio-avồ' do falecido para partilhar com a companheira o patrimônio construído durante esse tempo, e em posição mais vantajosa - ao menos a partir dos valores éticos adotados por este relator -, é solução que agride a mais prosaica concepção de 'justiça'.
} 
E isso independentemente de confronto com o regime sucessório aplicável ao casamento. É que essa predileção legal pelos parentes sucessíveis do falecido, inclusive de quarto grau, em detrimento da companheira, parece confrontar com a especial proteção constitucional conferida às famílias estabelecidas no art. 226 da Carta, entre as quais está a haurida da união estável." 110

E, no REsp. $\mathrm{n}^{\mathrm{o}}$ 1.135.354/PB, em que o Ministro também foi relator, concluiu:

"Com efeito, diante de tudo o que se me afigura correto sobre o tema e que foi exposto na fundamentação desenvolvida, tenho que os incisos III e IV do art. 1.790 do Código Civil não possuem lastro constitucional, devendo, portanto, ser declarada sua inconstitucionalidade."

A questão também já foi debatida pelo Supremo Tribunal Federal, que, em um primeiro momento, negou seguimento ao Recurso Extraordinário (AI 639997 AgR/SP), por entender que ainda que houvesse violação do inciso III, do artigo 1.790, do Código Civil, à Constituição Federal, essa violação ocorreria de modo reflexo ou indireto, razão pela qual seria necessário reexaminar a legislação ordinária aplicável a espécie, o que lhe é vedado em instância recursal.

Em uma segunda oportunidade, o Supremo Tribunal Federal reconheceu a existência de repercussão geral na controvérsia entre o dispositivo do Código Civil e o artigo 226 da Constituição Federal, em um caso de união estável homoafetiva, porém o Recurso Extraordinário ainda não foi julgado:

UNIÃO ESTÁVEL. COMPANHEIROS. SUCESSÃO. ARTIGO 1.790 DO CÓDIGO CIVIL. COMPATIBILIDADE COM A CONSTITUIÇÃO FEDERAL ASSENTADA NA ORIGEM. RECURSO EXTRAORDINÁRIO. REPERCUSSÃO GERAL CONFIGURADA. Possui repercussão geral a controvérsia acerca do alcance do artigo 226 da Constituição Federal, nas hipóteses de sucessão em união estável homoafetiva, ante a limitação contida no artigo 1.790 do Código Civil. ${ }^{112}$

\footnotetext{
${ }^{110}$ STJ. REsp. no 1.291.636-DF, Rel. Min. Luis Felipe Salomão, Brasília, 11 de junho de 2013.

${ }^{111}$ STJ. REsp. n ${ }^{\text {o }}$ 1.135.354/PB, Rel. Min. Luis Felipe Salomão, Brasília, 03 de outubro de 2012.

${ }^{112}$ STF. RE no 646721RG/RS, Rel. Ministro Marco Aurélio, Brasília, 17 de maio de 2011.
} 
Todos esses precedentes indicam que, provavelmente, será reconhecida a inconstitucionalidade do inciso III, do Código Civil, pois o dispositivo cria uma situação de grande desvantagem para o companheiro em relação aos parentes colaterais, se comparado ao regime sucessório do cônjuge.

\subsection{O COMPANHEITO COMO HERDEIRO ÚNICO}

Não existindo outros parentes sucessíveis, nos termos do inciso IV, do artigo 1.790, do Código Civil, o companheiro é chamado à sucessão como herdeiro único.

Conforme exposto acima, apesar do caput indicar que os direitos sucessórios só incidem sobre os bens adquiridos onerosamente na constância da união estável, a melhor interpretação seria aquela que busca evitar a herança vacante.

Assim, quando o companheiro for herdeiro único, seu direito sucessório incide sobre a totalidade dos bens deixados pelo autor da herança, independentemente de serem adquiridos antes da união estável ou gratuitamente.

\subsection{O COMPANHEIRO E O DIREITO REAL DE HABITAÇÃO}

Outra omissão do artigo 1.790, do Código Civil, se deu em relação ao direito real de habitação do companheiro, uma vez que o legislador deixou de mencioná-lo expressamente, ignorando a legislação anterior, que previa o instituto no parágrafo único, do artigo $7^{\circ}$, da Lei no 9.278/96.

Diante disso, surgiram controvérsias quanto à possibilidade do companheiro sobrevivente invocar ou não esse direito. Parte da doutrina argumenta que o Código Civil nada previu em suas disposições finais e 
transitórias quanto às Leis $n^{o s} 8.971 / 94$ e 9.278/96, de modo que não há que se falar em revogação do parágrafo único, do artigo $7^{\circ}$, da Lei n ${ }^{\circ}$ 9.278/96.

Essa posição está fundamentada, principalmente, no artigo $9^{\circ}$ da Lei Complementar $n^{\circ} 95$, segundo o qual a cláusula de revogação de uma lei deve enumerar, expressamente, as leis e disposições legais revogadas. Assim, o companheiro faria jus ao direito real de habitação, desde que preenchidos os requisitos exigidos por lei.

Em sentido contrário, há quem entenda que o companheiro sobrevivente não deve ser contemplado com esse direito, sob o argumento de que o Código Civil exauriu a matéria relacionada aos direitos sucessórios do companheiro no artigo 1.790, do Código Civil, afastando, pois, as leis acima mencionadas.

Portanto, segundo essa lógica, as leis teriam sido revogadas tacitamente, na forma do artigo $2^{\circ}, \S 1^{\circ}$, da Lei de Introdução ao Código Civil, já que o legislador teria feito a escolha de não prever no artigo 1.790, do Código Civil, o direito real de habitação para o companheiro sobrevivente.

Ademais, o fato do legislador ter garantido ao cônjuge sobrevivente, independentemente do regime de bens e sem prejuízo da parte que lhe caiba na herança, o direito real de habitação no artigo 1.831, do Código Civil, e não ter feito a mesma previsão para o companheiro no artigo 1.790 , do mesmo diploma, corrobora para a tese da revogação.

Ainda assim, a doutrina majoritária entende pela aplicação desse instituto na sucessão dos companheiros. Nas palavras de Sylvio Capanema, “diante do comando inserido no $\S 3^{\circ}$ do artigo 266 da Constituição Federal, não vemos como não estender ao companheiro a mesma proteção, tão necessária para preservação da dignidade humana" "113.

\footnotetext{
${ }^{113}$ SOUZA, Sylvio Capanema de. A Sucessão do Companheiro: Questões Controvertidas. Rio de Janeiro: Revista da Emerj, vol. 13, $\mathrm{n}^{\circ}$ 52, 2013. Disponível em http://www.emerj.tiri.jus.br/revistaemerj_online/edicoes/revista52/Revista52_17.pdf. Acessado em 05.10.2015.
} 
Nesse sentido, a I Jornada de Direito Civil aprovou o enunciado $\mathrm{n}^{\mathrm{o}}$ 117, com a seguinte redação:

"Enunciado no 117 - Art. 1.831: o direito real de habitação deve ser estendido ao companheiro, seja por não ter sido revogada a previsão da Lei n. 9.278/96, seja em razão da interpretação analógica do art. 1.831, informado pelo art. $6^{\circ}$ caput, da CF/88"

E, ainda, o Superior Tribunal de Justiça possui entendimento reiterado no sentido de garantir o direito real de habitação ao companheiro, a fim de evitar um tratamento desigual entre cônjuge e companheiro:

"DIREITO DAS SUCESSÕES. RECURSO ESPECIAL. SUCESSÃO ABERTA NA VIGÊNCIA DO CÓDIGO CIVIL DE 2002. COMPANHEIRA SOBREVIVENTE. DIREITO REAL DE HABITAÇÃO. ART. 1.831 DO CÓDIGO CIVIL DE 2002.

1. O novo Código Civil regulou inteiramente a sucessão do companheiro, ab-rogando as leis da união estável, nos termos do art. $2^{\circ}, \S 1^{\circ}$ da Lei de Introdução às Normas do Direito Brasileiro - LINDB.

2. É bem verdade que o art. 1.790 do Código Civil de 2002, norma que inovou o regime sucessório dos conviventes em união estável, não previu o direito real de habitação aos companheiros. Tampouco a redação do art. 1.831 do Código Civil traz previsão expressa de direito real de habitação à companheira. Ocorre que a interpretação literal das normas conduziria à conclusão de que o cônjuge estaria em situação privilegiada em relação ao companheiro, o que deve ser rechaçado pelo ordenamento jurídico.

3. A parte final do $\S 3^{\circ}$ do art. 226 da Constituição Federal consiste, em verdade, tão somente em uma fórmula de facilitação da conversão da união estável em casamento. Aquela não rende ensejo a um estado civil de passagem, como um degrau inferior que, em menos ou mais tempo, cederá vez a este.

4. No caso concreto, o fato de haver outros bens residenciais no espólio, um utilizado pela esposa como domicílio, outro pela companheira, não resulta automática exclusão do direito real de habitação desta, relativo ao imóvel da Av. Borges de Medeiros, Porto Alegre-RS, que lá residia desde 1990 juntamente com o companheiro Jorge Augusto Leveridge Patterson, hoje falecido.

5. O direito real de habitação concede ao consorte supérstite a utilização do imóvel que servia de residência ao casal com o fim de moradia, independentemente de filhos exclusivos do de cujus, como é o caso.

6. Recurso especial não provido."114

Portanto, segundo o entendimento majoritário, aplicado pelos tribunais, o direito real de habitação previsto pelo artigo 1.831, do Código Civil, deve ser aplicado, também, ao companheiro.

${ }^{114}$ STJ. REsp. no 1329993/RS. Rel. Min. Luis Felipe Salomão, Brasília. 17 de dezembro de 2013. 


\subsection{AFINAL, O REGIME SUCESSÓRIO DO COMPANHEIRO É BEM REGULADO?}

Pelo exposto, é possível observar que a doutrina e a jurisprudência estão bastante insatisfeitas com o regime sucessório do companheiro, regulado pelo artigo 1.790, do Código Civil. Como bem observa de Sylvio Capanema, com o Código Civil de 2002, "o regime jurídico da união estável, especialmente quanto aos direitos sucessórios, redundou em intolerável retrocesso, em grande prejuízo para os companheiros, o que é incompreensível, rompendo-se a coerente evolução do tema"115.

Diante disso, foi criado o Projeto de Lei $\mathrm{n}^{0}$ 6.960/2002, que, entre outras disposições, visa mudar a redação do artigo 1.790, do Código Civil, a fim de melhor regular a sucessão do companheiro. Assim, segundo o projeto, o artigo 1.790 passa a ter a seguinte redação:

“Art. 1.790. O companheiro participará da sucessão do outro na forma seguinte:

I- em concorrência com descendentes, terá direito a uma quota equivalente à metade do que couber a cada um destes, salvo se tiver havido comunhão de bens durante a união estável e o autor da herança não houver deixado bens particulares, ou se o casamento dos companheiros se tivesse ocorrido, observada a situação existente no começo da convivência, fosse pelo regime da separação obrigatória (art. 1.641);

II- em concorrência com ascendentes, terá direito a uma quota equivalente à metade do que couber a cada um destes;

III- em falta de descendentes e ascendentes, terá direito à totalidade da herança.

Parágrafo único. Ao companheiro sobrevivente, enquanto não constituir nova união ou casamento, será assegurado, sem prejuízo da participação que lhe caiba na herança, o direito real de habitação relativamente ao imóvel destinado à residência da família, desde que seja o único daquela natureza a inventariar".

Aparentemente, o projeto parece atender ao seu principal objetivo, já que altera várias partes do artigo, consideradas mal redigidas, ou até inconstitucionais, para melhor proteger o companheiro.

\footnotetext{
${ }^{115}$ SOUZA, Sylvio Capanema de. A Sucessão do Companheiro: Questões Controvertidas. Rio de Janeiro: Revista da Emerj, vol. 13, $\mathrm{n}^{\circ}$ 52, 2013. Disponível emhttp://www.emerj.tjij.jus.br/revistaemerj_online/edicoes/revista52/Revista52_17.pdf. Acessado em 05.10.2015.
} 
Questões como a massa de bens sobre a qual incide o direito sucessório do cônjuge, ou a previsão do companheiro como herdeiro único da totalidade dos bens deixados pelo autor da herança quando não houver outro parente sucessível, são aprimoradas no projeto.

De fato, o regime sucessório do companheiro, nos moldes atuais, representa um retrocesso às conquistas alcançadas pelas Leis $\mathrm{n}^{\mathrm{os}} 8.971 / 94 \mathrm{e}$ 9.278/96, permitindo que, em diversas situações, o companheiro tenha direitos sucessórios bem reduzidos se comparado ao cônjuge sobrevivente, ou até mesmo em relação aos outros herdeiros. 


\section{CONCLUSÃO}

Afinal, diante do exposto, qual seria o regime de bens que garante maior acervo patrimonial para o cônjuge ou companheiro? O que seria mais interessante, formalizar a relação ou viver em união estável?

Antes de analisarmos a questão proposta acima, é preciso fazer uma breve comparação entre os efeitos da aplicação das normas que regem a sucessão do cônjuge com as do companheiro. Vejamos

A primeira diferença que se coloca entre a sucessão do cônjuge e do companheiro se dá quanto à base de incidência dos direitos sucessórios. Como se viu, dependendo do regime de bens, o cônjuge, em concorrência com os descendentes, poderá ter direito (i) apenas à meação (comunhão total e separação obrigatória); (ii) à meação e a uma parcela dos bens particulares (comunhão parcial e participação final nos aquestos); ou (iii) somente a uma parcela da totalidade dos bens deixados pelo autor da herança (separação convencional). O companheiro, por sua vez, possui direito à meação e, ainda, a uma parcela dos bens adquiridos onerosamente durante a união estável, ou seja, sobre a meação do falecido.

Diante disso, para saber qual situação garantiria maior acervo patrimonial para o consorte sobrevivente, em concorrência com os descendentes, é preciso, antes de mais nada, verificar não apenas a proporção de bens particulares e de bens comuns, mas também relacionálos com as massas de bens sobre as quais incidem os direitos sucessórios dos consorte. Em outras palavras, a quantidade de bens particulares e bens comuns deixados pelo autor da herança será determinante para analisar qual regime de bens seria mais vantajoso economicamente para o cônjuge ou companheiro sobrevivente.

Além disso, o fato dos descendentes serem comuns ou exclusivos do autor da herança também influencia no cálculo do direito de concorrência. 
Isto porque, o cônjuge, em concorrência com os descendentes, terá a garantia da quota mínima de $1 / 4$ da massa de bens sobre a qual incidem os seus direitos sucessórios (artigo 1.832, do Código Civil), enquanto que o companheiro não possui qualquer direito à quota mínima.

Nesse contexto, apesar da regra de divisão do quinhão que se aplica ao companheiro que concorre com descendentes comuns e ao cônjuge ser a mesma - da divisão da herança em tantas partes quanto forem os herdeiros -, a partir do quarto filho os resultados serão diferentes.

Exemplifique-se, para melhor compreensão: se o casal de companheiros deu a luz a quatro filhos ou mais, após a morte de um deles, o companheiro sobrevivente terá direito a uma quota hereditária menor do que $1 / 4$, ao passo que, em razão da previsão de sua quota mínima, o cônjuge que se encontra em uma situação idêntica, nunca terá quota inferior à 1/4.

E, ainda mais absurdo, quando em concorrência com descendentes exclusivos do autor da herança, o companheiro receberá apenas metade do quinhão que couber aos enteados, calculado sobre a parte dos bens adquiridos onerosamente, durante a união estável. Enquanto que, no casamento, a parte da herança a que o cônjuge faz jus continuará sendo dividida em partes iguais entre o cônjuge e seus enteados, respeitando a quota mínima. Ou seja, para a mesma situações existem duas regras completamente diferentes para o casamento e para união estável.

Nos casos de concorrência com os ascendentes, as regras são ainda mais discrepantes. Conforme exposto no capítulo III, o cônjuge que concorre com os ascendentes do de cujus terá direito, independentemente do regime de bens, a uma parcela da totalidade da herança (artigo 1.837). O companheiro, por sua vez, ainda que em concorrência com ascendentes do autor da herança, terá direito apenas sobre a metade dos bens adquiridos onerosamente durante a união estável. Portanto, o companheiro continuaria a não ter qualquer direito sobre os bens particulares, que seriam transmitidos diretamente para os ascendentes. 
Seguindo essa lógica, percebemos que o cônjuge, ao concorrer com os pais do de cujus, teria direito à $1 / 3$ de toda a herança, ao passo que o companheiro teria direito apenas à $1 / 3$ dos bens adquiridos onerosamente na constância da união estável. E pior, se o autor da herança deixar apenas um ascendente, o cônjuge terá direito à metade da totalidade dos bens, enquanto que o companheiro continuará a ter direito apenas à $1 / 3$ dos bens adquiridos na vigência da união estável, nos termos do inciso II, do artigo 1.790 do Código Civil.

No entanto, a situação de maior discrepância ocorre na sucessão do cônjuge e do companheiro em concorrência com os parentes colaterais do falecido, na qual o cônjuge sobrevivente será herdeiro único, excluindo os parentes colaterais, ao passo que companheiro teria tão somente direito à 1/3 dos bens comuns. Essa situação causa espanto e é considerada inconstitucional pela grande maioria dos doutrinadores.

Por fim, apesar da controvérsia apontada no item 4.3, consolidou-se o entendimento de que, quando o autor da herança não tiver deixado outros parentes sucessíveis, ambos, cônjuge e companheiro, serão herdeiros únicos.

Como bem observa Maria Berenice Dias, "o que mais surpreende é o fato de ter a lei tratado de forma desigual
situações de vida idênticas [...], pois em nenhuma hipótese cônjuge e
companheiro recebem tratamento igual. Ainda que as situações sejam
absolutamente iguais, o resultado é sempre diferente."

Pelo exposto, é possível concluir que, na maioria das situações sucessórias, o casamento parece ser mais vantajoso economicamente do que a união estável.

Além disso, conforme analisado no Capítulo II, em regra, o casamento pelo regime da comunhão total é o regime que garante maior

\footnotetext{
${ }^{116}$ DIAS, Maria Berenice. Casar ou não casar? Dúvidas sobre questões sucessórias. Disponível em:http://mariaberenice.com.br/uploads/casar_ou_n\%E3o_casar_-_si\%281\%29.pdfAcessado em 05.10 .2015
} 
acervo patrimonial para o consorte sobrevivente, sendo, portanto, mais interessante, inclusive, do que a união estável.

Porém, é importante ressaltar que essa análise dependerá do caso concreto, já que, conforme demonstrado, os fatores determinantes para se chegar a conclusão, tais como as proporções das massas de bens comuns e particulares e a quantidade de filhos, variam de uma situação para outra.

No que concerne ao casamento, conforme analisado no Capítulo I, o regime mais vantajoso também parece ser o regime da comunhão universal de bens, uma vez que, nesse regime, há maior comunicabilidade de patrimônios.

Cabe relembrar, no entanto, que, assim como no casamento, na ausência de estipulação quanto ao regime de bens, serão aplicadas à união estável, as regras da comunhão parcial de bens. Desse modo, para que o regime da comunhão total incida sabre o casamento ou sobre a união estável, é necessária a celebração de um pacto antenupcial ou de convivência, respectivamente, com tal previsão.

Conforme apontado acima, nas hipóteses em que a lei prevê a imposição do regime de separação obrigatória, a escolha entre a união estável e o casamento pode produzir resultados diferentes.

Isto porque, não se aplicam as causas impeditivas previstas para o casamento à união estável (artigo 1.641 do Código Civil), de modo que os companheiros poderiam lavrar uma escritura pública constitutiva de união estável, estipulando livremente sobre aspectos patrimoniais, sem que isso represente uma violação ao ordenamento jurídico, conforme ensina Maria Berenice Dias:

\footnotetext{
"As limitações impostas à vontade dos noivos torna mais vantajosa a união informal. Diante da vedação a livre eleição do regime de bens, a solução mais lógica é simplesmente abandonar a ideia de sacramentar a união pelo casamento. Mas, como persiste o desejo de constituição de família, para afastar as restrições legais, o jeito é viver em união estável, pois não vigoram quaisquer impedimentos. Pelos precisos termos do art. 1.725 do CC, na união estável o regime é o da comunhão parcial, e não há maneira mais fácil de adotar o regime que melhor atende à realidade
} 
da vida e à vontade do par, afastando a intervenção estatal, do que escolher essa modalidade de convívio.

[...] Outros subterfúgios são utilizados em larga escala, como a lavratura de escritura publica constitutiva da união estável, em que podem livremente ser feitas estipulações de aspectos patrimoniais sem qualquer afronta à normatização jurídica." $" 117$

No mais, tanto na dissolução da união estável, como do casamento, por separação, a regra é que o regime com maior comunicabilidade permite maior aquisição patrimonial para o consorte que possuía menor patrimônio antes do início da relação.

Assim, a melhor estratégia é evitar os regimes da separação obrigatória e o da separação convencional de bens, em que há a previsão de separação completa de patrimônios.

${ }^{117}$ DIAS, Maria Berenice. Art. 1641: inconstitucionais limitações ao direito de amar. Disponível em:http://www.mariaberenice.com.br/uploads/1 art. 1641 inconstitucionais limita\%E7\%F5es ao_direito_de_amar.pdf Acessado em 20.06.2015 


\section{BIBLIOGRAFIA}

ALMEIDA, José Luiz Gavião de. Comentários ao Código Civil, vol. XXIII. São Paulo: Atlas, 2009. P. 252 apud TEPEDINO, Gustavo et al.. Código Civil Interpretado: Conforme a Constituição da República, vol. IV. $1^{a}$ ed. Rio de Janeiro: Renovar, 2014.

ARAÚJO, Luciano Vianna. Ordem de vocação hereditária no novo Código Civil: os direitos sucessórios do cônjuge. in ADV - Advocacia Dinâmica, Rio de Janeiro, 2002.

CARVALHO, Luiz Paulo Vieira de. Direito Civil: questões fundamentais e controvérsias na parte geral, no direito de família e no direito das sucessões. $4^{\circ}$ ed. Rio de Janeiro: Impetus, 2010.

DIAS, Maria Berenice. Art. 1641: inconstitucionais limitações ao direito de amar. Disponível em: http://www.mariaberenice.com.br/uploads/1_art._1641_inconstitucionais limita\%E7\%F5es ao direito de amar.pdf Acessado em 20.06.2015.

- Casar ou não casar? Dúvidas sobre questões

sucessórias. Disponível em: http://mariaberenice.com.br/uploads/casar_ou_n $\%$ E3o casar_si $1 \% 281 \% 29$.pdf. Acessado em 05.10.2015. . Manual das Sucessões. $3^{\mathrm{a}}$ ed. São Paulo: Editora dos Tribunais, 2013. . Manual de Direito das Famílias. 10ªd. São Paulo: Editora Revista dos Tribunais, 2015. 298 p.

Ponto-e-vírgula. Disponível em: http://mariaberenice.com.br/uploads/1_ ponto_e_v\%EDrgula.pdf. Acessado em 15.09.2015.

FARIA, Mario Roberto Carvalho de. Direito das Sucessões: teoria e prática. $7^{\mathrm{a}}$ ed. Rio de Janeiro: Forense, 2013. 
GONÇALVES, Carlos Roberto. Direito Civil Brasileiro: Direito de Família, vol. VI. 6a ed. São Paulo: Saraiva, 2009.

HIRONAKA, Gisela Maria Fernandes Novaes. Comentários ao Código Civil: parte especial do direito das sucessões, vol. 20. São Paulo: Saraiva, 2003. P. 220 apud TEPEDINO, Gustavo et al.. Código Civil Interpretado: Conforme a Constituição da República, vol. IV. 1ª ed. Rio de Janeiro: Renovar, 2014.

LÔBO, Paulo. Direito Civil: Famílias. 4ª ed. São Paulo: Saraiva, 2011.

. Direito Civil: Sucessões. $1^{\mathrm{a}}$ ed. São Paulo: Saraiva, 2013.

MADALENO, Rolf. Curso de Direito de Família. 5a ed. Rio de Janeiro: Forense, 2013.

- O Novo Direito Sucessório Brasileiro. Disponível em: $\quad$ http://www.rolfmadaleno.com.br/novosite/conteudo.php?id=42. Acessado em 28.09.2015.

MARTINS-COSTA Judith. REALE, Miguel. "Direito Civil. Sucessões. Casamento sob o regime de separação total de bens, voluntariamente escolhido pelos nubentes. apud NEVARES, Ana Luiza Maia. A sucessão do cônjuge e do companheiro na perspectiva do direito civil-constitucional. $2^{\mathrm{a}}$ ed. São Paulo: Atlas, 2015.

MIRANDA, Pontes de. Tratado de Direito de Família: volume II. $3^{\mathrm{a}}$ ed. São Paulo: Max Limonad, 1947.

NEVARES, Ana Luiza Maia. A sucessão do cônjuge e do companheiro na perspectiva do direito civil-constitucional. $2^{\mathrm{a}}$ ed. São Paulo: Atlas, 2015.

Partilha de bens em união estável no regime de separação obrigatória exige prova de esforço comum”. Disponível em http://www.stj.jus.br/sites/STJ/default/pt BR/noticias/noticias/Partilha-debens-em-uni\%C3\%A3o-est\%C3\%A1vel-no-regime-desepara\%C3\%A7\%C3\%A3o obrigat\%C3\%B3ria-exige-prova-deesfor\%C3\%A7o-comum. Acessado em 15.09.2015. 
PEREIRA, Caio Mário da Silva. Instituições de Direito Civil: Direito de Família, vol. V. $23^{a}$ ed. atualizado por Tânia da Silva Pereira. Rio de Janeiro: Forense, 2015. 192 p.

- Instituições de Direito Civil: Direito das

Sucessões, vol. VI. $21^{\mathrm{a}}$ ed. atualizado por Carlos Roberto Barbosa Moreira. Rio de Janeiro: Forense, 2014. 143 p.

RIZZARDO, Arnaldo. Direito de Família. $6^{\mathrm{a}}$ ed. Rio de Janeiro: Forense, 2008. $660 \mathrm{p}$.

SOUZA, Sylvio Capanema de. A Sucessão do Companheiro: Questões Controvertidas. Rio de Janeiro: Revista da Emerj, vol. 13, $\mathrm{n}^{\mathrm{o}}$ 52, $2013 . \quad$ Disponível em: http://www.emerj.tjrj.jus.br/revistaemerj_online/edicoes/revista52/Revista5 2 17.pdf. Acessado em 05.10.2015.

STF. RE nº 646721RG/RS, Rel. Min. Marco Aurélio, Brasília, 17 de maio de 2011.

STJ, REsp. $\mathrm{n}^{0}$ 1.368.123-SP, Rel. Min. Sidnei Beneti, Brasília, 22 de abril de 2015.

STJ. 992749/MS, Rel. Min. Nancy Andrighi, Brasília, $1^{\circ}$ de dezembro de 2009.

STJ. MC no 14.509/SP. Rel. Min. Nancy Andrighi, Brasília, 21 de agosto de 2008.

STJ. REsp. $\mathrm{n}^{\circ}$ 1.117.563-SP, Rel. Min. Nancy Andrighi, Brasília, 06 de abril de 2010 .

STJ. REsp. $\mathrm{n}^{\mathrm{o}}$ 1.377.084-MG, Rel. Min. Nancy Andrighi, Brasília, 15 de outubro de 2013.

STJ. REsp. no 1.135.354/PB, Rel. Min. Luis Felipe Salomão, Brasília, 03 de outubro de 2012.

STJ. REsp. $\mathrm{n}^{\circ}$ 1.291.636-DF, Rel. Min. Luis Felipe Salomão, Brasília, 11 de junho de 2013. 
STJ. REsp. no 1329993/RS. Rel. Min. Luis Felipe Salomão, Brasília. 17 de dezembro de 2013.

STJ. REsp. n 974.241-DF, Rel. Min. Luis Felipe Salomão, Brasília, 05 de outubro de 2015.

STJ. REsp. $n^{\text {o }}$ 1.368.123. Rel. Min. Sidnei Beneti, Brasília, 22 de abril de 2015.

STJ. REsp. n 1.382.170-SP, Rel. Min. João Otávio de Noronha, Brasília, 22 de abril de 2015.

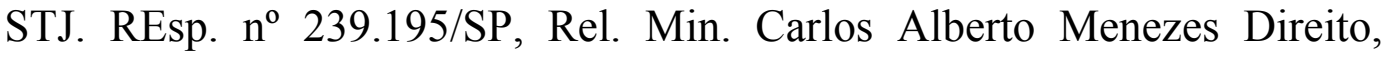
Brasília, 20 de setembro de 2001.

TARTUCE, Flávio. Manual de Direito Civil: volume único. $5^{\circ}$ ed. São Paulo: Método, 2015. 1.171 p.

TEPEDINO, Gustavo et al.. Código Civil Interpretado: Conforme a Constituição da República, vol. IV. 1 ${ }^{\text {a }}$ ed. Rio de Janeiro: Renovar, 2014.

TJRJ. Apelação Cível no 0215978-16.2009.8.19.0001, Rel. Des. Maria Regina Nova Alves, Rio de Janeiro, 22 de abril de 2015.

TUCCI, Cibele Pinheiro Marcal. Aspectos Patrimoniais do Direito de Família no Brasil. In: AZEVEDO, Álvaro Vilaça (Org.) Revista Nacional de Família e Sucessões. Porto Alegre: Magister, 2014. p. 37-57.

TUCCI, José Rogério Cruz. Jurisprudência sobre sucessão do cônjuge é instável. Disponível em http://www.conjur.com.br/2013-dez-10/paradoxocorte-jurisprudencia-sucessao-conjuge-instavel. Acessado em 28.09.2015. 
Projeto de Lei $\mathrm{n}^{\circ} 2.285 / 2007$

SEÇÃO VI

DOS REGIMES DE BENS

\section{SUBSEÇÃO I \\ DISPOSIÇÕES COMUNS}

Art. 38. Podem os nubentes estipular, quanto aos seus bens, o que lhes aprouver.

$\S 1^{\circ}$ Os nubentes, mediante declaração ao oficial de registro civil, podem escolher qualquer dos regimes de bens estabelecidos neste Estatuto.

$\S 2^{\circ}$ Não havendo declaração, vigora o regime da comunhão parcial de bens.

$\S 3^{\circ}$ Mediante escritura publica os nubentes podem estipular regime de bens não previsto neste Estatuto, desde que não contrarie suas regras e princípios.

$\S 4^{\circ} \mathrm{O}$ regime de bens começa a produzir efeitos na data do casamento e cessa com o fim da comunhão de vida.

$\S 5^{\circ}$ Com a separação de fato cessa a responsabilidade de cada um dos cônjuges para com as dividas que vierem a ser contraídas pelo outro.

Art. 39. É admissível a alteração do regime de bens, mediante escritura publica, promovida por ambos os cônjuges, assistidos por advogado ou defensor publico, ressalvados os direitos de terceiros.

$\S 1^{\circ}$ A alteração não dispõe de efeito retroativo.

$\S 2^{\circ} \mathrm{A}$ alteração produz efeito a partir da averbação no assento de casamento. livremente:

Art. 40. Independentemente do regime de bens, qualquer dos cônjuges pode

I- administrar e alienar os bens particulares, exceto os bens móveis que guarnecem a residência da família;

II- praticar os atos de disposição e administração necessários ao desempenho de sua profissão;

III- reivindicar os bens comuns, doados, gravados ou transferidos pelo outro cônjuge sem o seu consentimento;

IV- demandar a resolução dos contratos de fiança e doação, realizados pelo outro cônjuge.

$\S 1^{\circ}$ As ações fundadas nos incisos III e IV competem ao cônjuge prejudicado e a seus herdeiros.

$\S 2^{\circ} \mathrm{O}$ terceiro prejudicado tem direito regressivo contra o cônjuge que realizou o negocio jurídico, ou contra os seus herdeiros.

Art. 41. Pode o cônjuge, independentemente da autorização do outro:

I- comprar, ainda que a credito, o necessário à manutenção da família;

II- obter, por empréstimo, as quantias que tais aquisições possam exigir.

Parágrafo único. As dividas contraídas para os fins deste artigo obrigam solidariamente ambos os cônjuges.

Art. 42. Nenhum dos cônjuges pode, sem autorização do outro, exceto no regime da separação:

I- vender, doar, permutar, dar em pagamento, ceder ou gravar de ônus real os bens comuns; 
II- pleitear, como autor ou réu, acerca desses bens ou direitos;

III- prestar fiança.

Parágrafo único. Cabe o suprimento judicial do consentimento quando um dos cônjuges o denegue sem motivo justo, ou lhe seja impossível concedê-lo.

Art. 43. A anulação dos atos praticados sem outorga, sem consentimento, ou sem suprimento do juiz, pode ser demandada pelo cônjuge a quem cabia concedê-lá, ou por seus herdeiros, até um ano da homologação da partilha.

Art. 44. Quando um dos cônjuges não puder exercer a gestão dos bens que lhe incumbe, cabe ao outro:

I- gerir os bens, comuns ou não;

II- alienar os bens móveis comuns;

III- alienar os imóveis e os bens móveis, comuns ou não, mediante autorização judicial.

\section{SUBSEÇÃO II \\ DO REGIME DE COMUNHÃO PARCIAL}

Art. 45. No regime de comunhão parcial, comunicam-se:

I- os bens adquiridos na constância do casamento, inclusive as economias derivadas de salários, indenizações, verbas trabalhistas rescisórias e rendimentos de um só dos cônjuges;

II- os bens adquiridos por fato eventual, com ou sem o concurso de trabalho ou despesa;

III- os bens recebidos por doação, herança ou legado, em favor de ambos os cônjuges;

IV- as pertenças e as benfeitorias em bens particulares de cada cônjuge;

$\mathrm{V}$ - os frutos dos bens comuns, ou dos particulares de cada cônjuge, percebidos na constância do casamento, ou pendentes quando cessada a vida em comum

Art. 46. Excluem-se da comunhão:

I- os bens que cada cônjuge possuir ao casar, e os que lhe sobrevierem, na constância do casamento, por doação ou sucessão, e os sub-rogados em seu lugar;

II- os bens adquiridos com valores exclusivamente pertencentes a um dos cônjuges ou em sub-rogação dos bens particulares;

III- as obrigações anteriores ao casamento, salvo se reverterem em proveito comum;

IV- as obrigações provenientes de ato ilícito, salvo reversão em proveito do casal;

V- os bens cuja aquisição tiver por titulo causa anterior ao casamento;

VI- os bens de uso pessoal, os livros e instrumentos de profissão.

$\S 1^{\circ}$ Os instrumentos de profissão incluem-se na comunhão quando houver a participação do outro na sua aquisição.

$\S 2^{\circ}$ Presumem-se adquiridos na constância do casamento os bens moveis, quando não provado que o foram em data anterior.

Art. 47. A gestão do patrimônio comum compete a ambos os cônjuges.

$\S 1^{\circ}$ É necessária a anuência de ambos os cônjuges para os atos, a titulo gratuito, que impliquem cessão do uso ou gozo dos bens comuns.

$\S 2^{\circ}$ Em caso de malversação dos bens comuns, ou de outra hipótese similar, pode ser atribuída a gestão a apenas um dos cônjuges ou antecipada a partilha. 
Art. 48. Os bens da comunhão respondem pelas obrigações contraídas por qualquer dos cônjuges para atender aos encargos da família, às despesas de gestão e às decorrentes de imposição legal.

Art. 49. A gestão dos bens constitutivos do patrimônio particular compete ao cônjuge proprietário, salvo estipulação diversa.

Art. 50. As dividas, contraídas por qualquer dos cônjuges na administração e em beneficio de seus bens particulares, não obrigam os bens comuns.

Parágrafo único. As dividas contraídas por qualquer dos cônjuges obrigam os bens do outro na razão do proveito que houver auferido.

\section{SUBSEÇÃO III \\ DO REGIME DA COMUNHÃO UNIVERSAL}

Art. 51. O regime de comunhão universal importa a comunicação de todos os bens presentes e futuros dos cônjuges e de suas dividas.

Art. 52. São excluídos da comunhão:

I- os bens doados ou herdados com a cláusula de incomunicabilidade e os subrogados em seu lugar;

II- as dividas anteriores ao casamento, salvo se reverterem em proveito comum;

III- as obrigações provenientes de ato ilícito;

IV- os bens de uso pessoal, os livros e instrumentos de profissão.

$\S 1^{\circ}$ Os instrumentos de profissão entram na comunhão se foram adquiridos com esforço do outro cônjuge.

$\S 2^{\circ} \mathrm{A}$ incomunicabilidade não se estende aos frutos, quando se percebam ou vençam durante o casamento.

\section{SUBSEÇÃO IV \\ DO REGIME DE SEPARAÇÃO DE BENS}

Art. 53. O regime da separação de bens importa incomunicabilidade completa dos bens adquiridos antes e durante o casamento.

Parágrafo único. Os bens ficam na administração exclusiva do respectivo cônjuge, que os poderá livremente alienar ou gravar de ônus real. 